Ref-Rdy

QH70

. U52N4 1

1911 


\section{FOR THE PEOPLE} FOR EDVCATION FOR SCIENCE

$$
\text { LIBRARY }
$$

OF THE AMERICAN MUSEUM OF NATURAL HISTORY 

, 


\title{
American Museum of Natural History
}

\section{Seventy-seventh Street and Central Park West, New York City}

\section{BOARD OF TRUSTEES}

\author{
President \\ Henry Fatrfield Osborn
}

First Vice-President

Second Vice-President

Cueveland H. Dodge

J. Pierpont Morgan, Jr.

Treasurer

Charles Lanier

Secretary

Archer M. Huntington

The Mayor of the City of New York

The Comptroller of the City of New York

The President of the Department of Parks

\author{
Albert S. BicKMORE \\ GeORge S. Bowdorn \\ Joseph H. Chonte \\ Thomas DeWitt Cuyler \\ James Douglas \\ Madison Grant \\ ANSON W. Hard \\ Adrian Iselin, Jr. \\ Arthur Curtiss James \\ W ALTER B. JAMES
}

\author{
A. D. Juilliard \\ Gustay E. Kissel * \\ SETH Low \\ Ogden Mrlus \\ J. Pierpont Morgan \\ Percy R. Pyne \\ William ROCKEFELLER \\ John B. Trevor \\ Felix M. Warburg \\ George W. Wickersham
}

\section{EXECUTIVE OFFICERS}

Director

Frederic A. Lucas

\section{Assistant Secretary}

George H. Sherwood

\author{
Assistant Treasurer \\ The United States Trust Company of New York \\ * Deceased
}

The Museum is Open Free to the Public on Every Day in the Year.

The American Museum of Natural History was established in 1869 to promote the Natural Sciences and to diffuse a general knowledge of them among the people, and it is in cordial coöperation with all similar institutions throughout the world. The Museum authorities are dependent upon private subscriptions and the dues from members for procuring needed additions to the collections and for carrying on explorations in America and other parts of the world. The membership fees are,

\begin{tabular}{|c|c|c|c|}
\hline Annual Membe & $\$ 10$ & Fellows. . & $\$ 500$ \\
\hline Sustaining Members (Annual) & 25 & Patrons.... & 1000 \\
\hline Life Members. . . . . . . . . & 100 & Benefactors (Gift or bequest) & 50,000 \\
\hline
\end{tabular}

The MUseum Library contains more than 60,000 volumes with a good working collection of publications issued by scientific institutions and societies in this country and abroad. The library is open to the public for reference daily - Sundays and holidays excepted - from $9 \mathbf{A}$. M. to 5 P. M.

The Museum Poblications are issued in six series: The American Museum Journal, Annual Report, Anthropological Papers, Bulletins, Guide Leaflets and Memoirs. Information concerning their sale may be obtained at the Museum Library.

GUIDES FOR STUDY of ExhIBITS are provided on request by the Department of Public Education. Teachers wishing to bring classes should write or telephone the Department for an appointment, specifylng the collection to be studied. Lectures to classes may also be arranged for. In all cases the best results are obtained with small groups of children.

WORKROOMs AND STORAGE COLLECTIONS may be visited by persons presenting membership tíckets. The storage collections are open to all persons desiring to examine specimens for special study. Applications should be made at the information desk.

The Mitla Restaurant in the east basement is reached by the elevator and is open from 12 to 5 on all days except Sundays. Afternoon Tea is served from 2 to 5 . The Mitla Room is of unusual interest as an exhibition hall being an exact reproduction of temple ruins at Mitla, Mexico. 


\title{
Scientific Staff
}

\author{
DIRECTOR \\ Frederic A. Lucas, Sc.D.
}

\section{GEOLOGY AND INVERTEBRATE PALEONTOLOGY}

Edmund Otis Hovex, A.B., Ph.D., Curator

\section{MINERALOGY}

L. P. Gratacap, Ph.B., A.B., A.M., Curator

George F. Kunz, A.M., Ph.D., Honorary Curator of Gems

\section{INVERTEBRATE ZOÖLOGY}

Prof. Henry E. Crampton, A.B., Ph.D., Curator Roy W. Miner, A.B., Assistant Curator

Frank E. Lutz, A.B., A.M., Ph.D., Assistant Curator L. P. Gratacap, Ph.B., A.B., A.M., Curator of Mollusca William Beutenmüllerer, Associate Curator of Lepidoptera John A. Grossbeck, Assistant

Prof. William Morton Wheeler, rn.D., Honorary Curator of Social Insects Alexander Petrunkevitch, Ph.D., Honorary Curator of Arachnida

Prof. Aaron L. Treadwell, B.S., M.S., Ph.D., Honorary Curator of Annulata Charles W. Leng, B.S., Honorary Curator of Coleoptera

\section{ICHTHYOLOGY AND HERPETOLOGY}

Prof. Bashford Dean, A.B., A.M., Ph.D., Curator of Fishes and Reptiles

Louis Hussakof, B.S., Ph.D., Associate Curator of Fishes

JoHn T. Nichols, A.B., Assistant Curator of Recent Fishes

Mary Cynthia Dickerson, B.S., Assistant Curator of Herpetology

\section{MAMMALOGY AND ORNITHOLOGY}

Prof. J. A. Allen, Ph.D., Curator

Frank M. Chapman, Curator of Ornithology

Roy C. Andrews, A.B., Assistant Curator of Mammalogy

W. De W. Miller, Assistant Curator of Ornithology

\section{VERTEBRATE PALAONTOLOGY}

Prof. Henry Fatrfield Osborn, A.B., Sc.D., LL.D., D.Sc., Curator Emeritus

W. D. Matthew, Ph.B., A.B., A.M., Ph.D., Curator

Walter Granger, Associate Curator of Fossil Mammals

Barnum Brown, A.B., Associate Curator of Fossil Reptiles

William K. Gregory, A.B., A.M., Ph.D., Assistant Curator

\section{ANTHROPOLOGY}

Clark Wissler, A.B., A.M., Ph.D., Curator

Pliny E. Goddard, A.B., A.M., Ph.D., Associate Curator

Robert H. Lowie, A.B., Ph.D., Assistant Curator

Herbert J. Spinden, A.B., A.M., Ph.D., Assistant Curator

$$
\text { Charles W. Mead, Assistant }
$$

Alanson Skinner, Assistant

\section{PHYSIOLOGY}

Prof. Ralph W. Tower, A.B., A.M., Ph.D., Curator

\section{PUBLIC HEALTH}

Prof. Charles-Edward Amory Winslow, S.B., M.S., Curator John Henry O'Neill, S.B., Assistant

WOODS $\overline{A N D \text { FORESTRY }}$

Mary Cynthia Dickerson, B.S., Curator BOOKS AND PUBLICATIONS

Prof. Ralph W. Tower, A.B., A.M., Ph.D., Curator

$$
\text { PUBLIC EDUCATION . }
$$

Prof. Albert S. Bickmore, B.S., Ph.D., LL.D., Curator Emeritus George H. Sherwood, A.B., A.M., Curator 


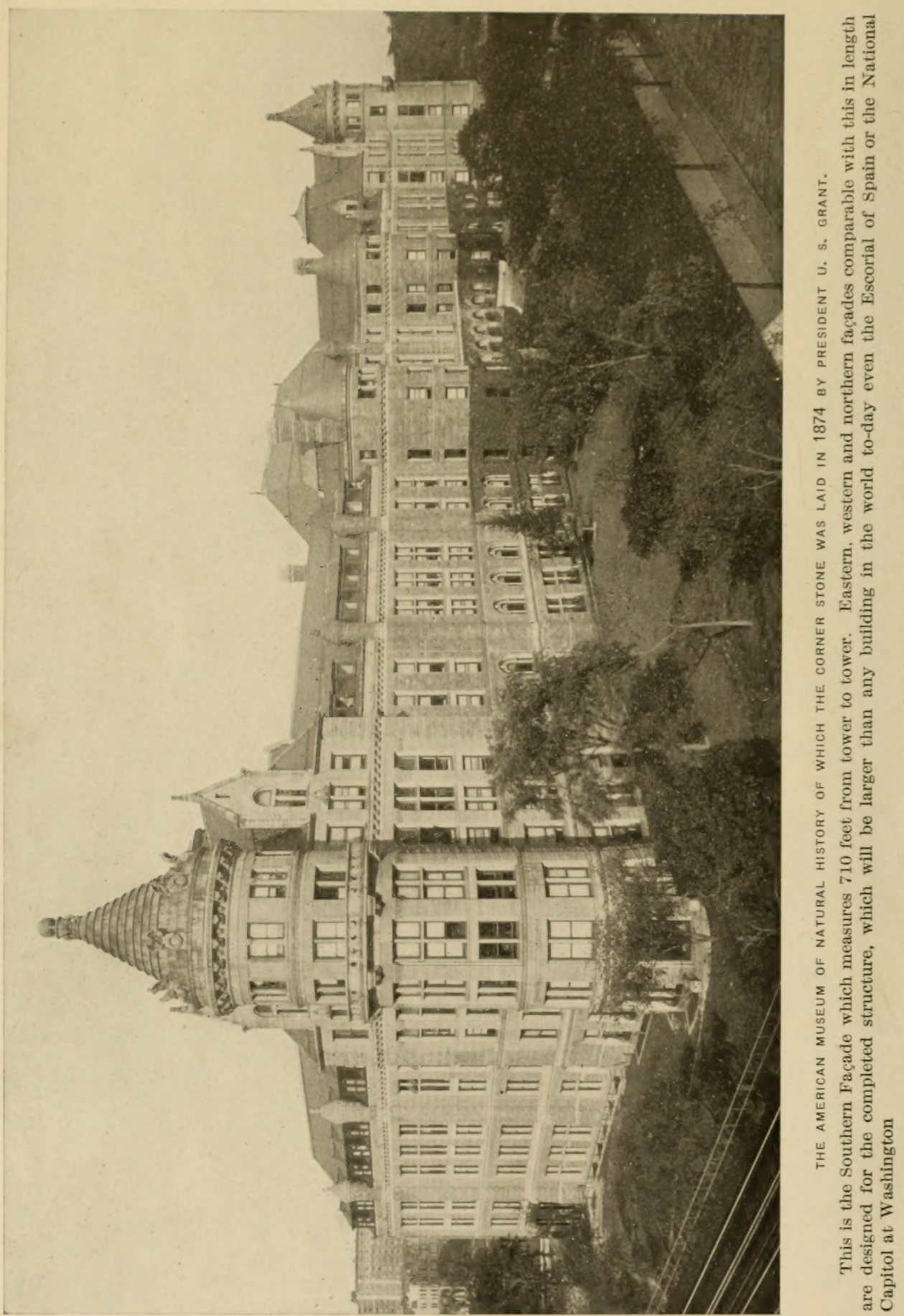




\section{GENERAL GUIDE}

\section{TO THE \\ $5.07(74.78)$ \\ Exhibition Halls \\ OF THE}

AMERICAN MUSEUM OF NATURAL HISTORY

Prepared by GEORGE H. SHERWOOD

Curator of Public Education

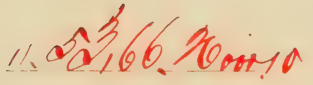

NO. 35

OF THE

GUIDE LEAFLET SERIES

OF THE

AMERICAN MUSEUM OF NATURAL HISTORY MARY CYNTHIA DICKERSON, Editor

New York. Published by the Museum. November, 1911 


\section{(') NTENTS}

Index of Exhmition Halls. Page

INTRDDCTION .................................. 11

History of the Museum

Lociation

Hour's of Admission

Administration and Support

First FlLoor

Information Bureat ..................... 13

Memorial Hall (śmuth Pavilion).

Statue of Morris K. Jesup . . . . . . . . . . . . . . . . . . . . . . . .

Meterites. . 14

Model of Solar System . . . . . . . . . . . . . 14

Indians of the North Pacific Coast (South Central Wing)........

Indians of British Columbia and Alaska; Eskimo Collections

Mural Decorations

Auditorium (Central Pavilion)............................ 1s

Power Room (West Central Wing).................... 1s

Ward-Coonley Meteorites (West Corridor)................. in

Indians of the Woodlands (Southwest Wing) ............... 19

Including all tribes east of the Mississippi: Iroquois, New York Indians, Seminole, Menomini, Winnebago, Cree, Ojibwa and Delaware

Indians of the Plains (Southwest Pavilion)

Comprising tribes between the Mississippi and the Rocky Mountains: Plains Cree, Dakota, Crow, Blackfoot, Mandan, Pawnee, Kiowa and Cheyenne

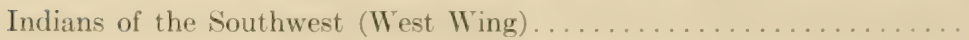

Sedentary Indians: Rio Grande Pueblo, Prehistoric Pueblo Bonito, Hopi, Prehistoric Cliff Dwellers and Zuni:

Nomadic Indians: Apache, Navajo, Pima and Mexican Indians

Polar Expeditions (East Corridor) . . . . . . . . . . . . . . . . . 2 .

Jesup Collection of North American Woods (Southeast Wing) . . . . . . . 24

Darwin Hall: Invertebrates (Southeast Pavilion) . . . . . . . . . . . 2?

The series in the alcove cases gives a synopsis of the Animal Kingdom and includes Protozoa, Sponges, Polyps, Flatworms, Roundworms, Rotifers, Sea-mats, Starfish, Annelids, Arthropods, Mollusks and Vertebrates

('oral

Malaria Mosquito

SECOND FLOOR

Astronomical Clock (South Pavilion) . . . . . . . . . . . . . . . . . . . . . . . . . . . . . .

Mammals (South Pavilion). . . . . . . . . . . . . . . . .

Dogs, small carnivores, the Barbary Lion "Hannibal" and the elephant "Tip"

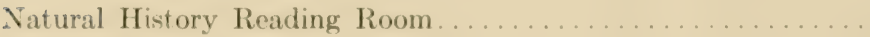

Children's Room..................................... 36

Reom for the Blind.

Mitlat Rums (southwest Pavilion and Restamant in Basement). 
Ancient Monuments of Mexico and Central America (Southwest Wing)

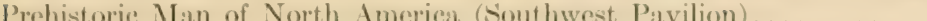

Collections from Africa (West Wing).................... 4

The hippopotamus "Caliph"

Congo Collections

Birds of the World (South Central Wing) . . . . . . . . . . . . . .

Recent Fishes (Corridor of Central Pavilion) .................. 11

Mammals of North America (Southeast Wing) . . . . . . . . . . . . . . . 4.)

Mammals of the Polar Regions (Southeast Pavilion) . . . . . . . . . . . . 4 !

Reptiles and Amphibians (Southeast Pavilion) .............. j1

Third FLOOR

Monkeys, Apes and Primitive Man (South Pavilion).............. 55

Rodents (Nouth Pavilion) ........................... 55

North Atlantic Right Whale (South Pavilion) . . . . . . . . . . . 55

Habitat Groups of North American Birds (South Central Wing) . . . . . . . 57

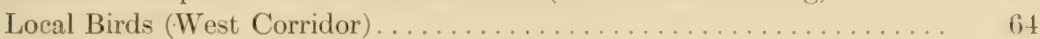

Indians of South America (Southwest Wing) ................ (6.5

Chinese and Siberian Collections (Southwest Pavilion) . . . . . . . . . 69

Shells (West Wing) . . . . . . . . . . . . . . . . . . . . . . . 69

Mammals of the World (Southeast Wing) ..................

Hall of Insect Life (Southeast Pavilion) . . . . . . . . . . . . . . 71

\section{Fourth Floor}

Foreword on Fossil Vertebrates........................ 7 :

Fossil Fishlike Lizards (West Corridor). . . . . . . . . . . . . . . . . 74

Mastodons and Mammoths (South Pavilion)............... 7 t

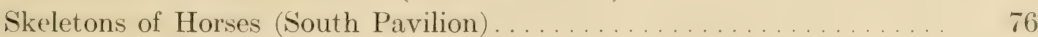

Fossil Mammals of the Tertiary Period (Southeast Wing) . . . . . . . . . 77

Fossil Reptiles and Fishes (Southeast Pavilion) . . . . . . . . . . . . . . 81

Geology and Invertebrate Palæontology (South Central Wing) . . . . . . 87

Gems and Precious Stones (West Corridor) .................. 91

Minerals (Southwest Wing) . . . . . . . . . . . . . . . . . . 91

Collections from the Pacific Islands (Southwest Pavilion) . . . . . . . . . . 93

Collections from the Philippines (West Wing) . . . . . . . . . . . . . 93

Fifth FLOOR

Library . . . . . . . . . . . . . . . . . . . . . . . . . . 94

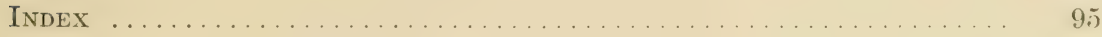




\section{PREFATORY NOTE}

It is the purpose of this Gurde to call attention to the more important exhibits that the visitor will see as he passes through the halls. More detailed information regarding the specimens may be ohtained from the labeds or from the Giaide Lenflets.

It is frequently necessary to rearrange the exhibits in the halls in order to provide space for new material which is continually being received or to put into effect advanced ideas regarding methods of exhibition. In some instances therefore, the arrangement deseribed is not wholly that in existence at the date of issue of the GuIDE, but rather what will be when certain installations now in progress are completed. This is true for the halls devoted to geology and invertebrate palarontology and to some extent in the exhibit of the Indians of the Woodlands and in those of local mammals, mammals of the world and insects. The sergeants on each floor will always direct the visitor to any collection on the given floor

American Meseum of Natural History, November, 1911.

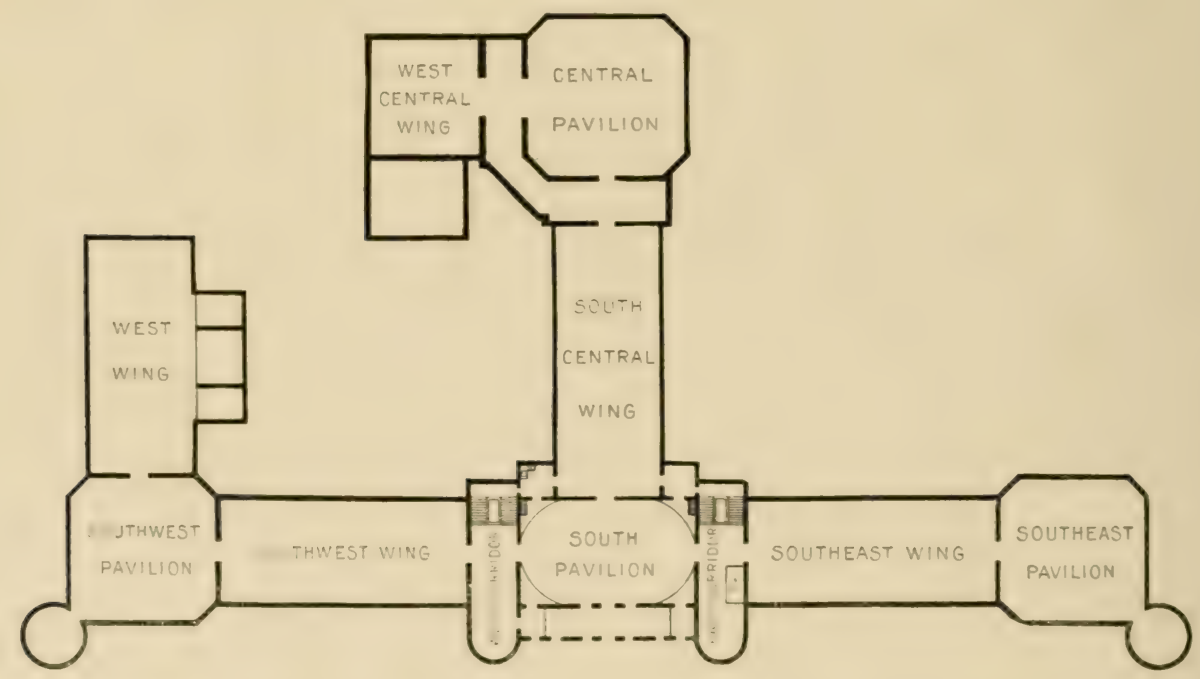

The halls are named according to the position they will have in the completed Museum building, which will consist of four long façades facing east, west, north and south respectively, each connected with the center of the quadrangle formed, by a wing extending between open courts. Thus the hall at the eastern end of the south façade (the only façade completed) becomes the "southeast pavilion." $s$ 


\section{INIOEX OF EXHIBITION HALA}

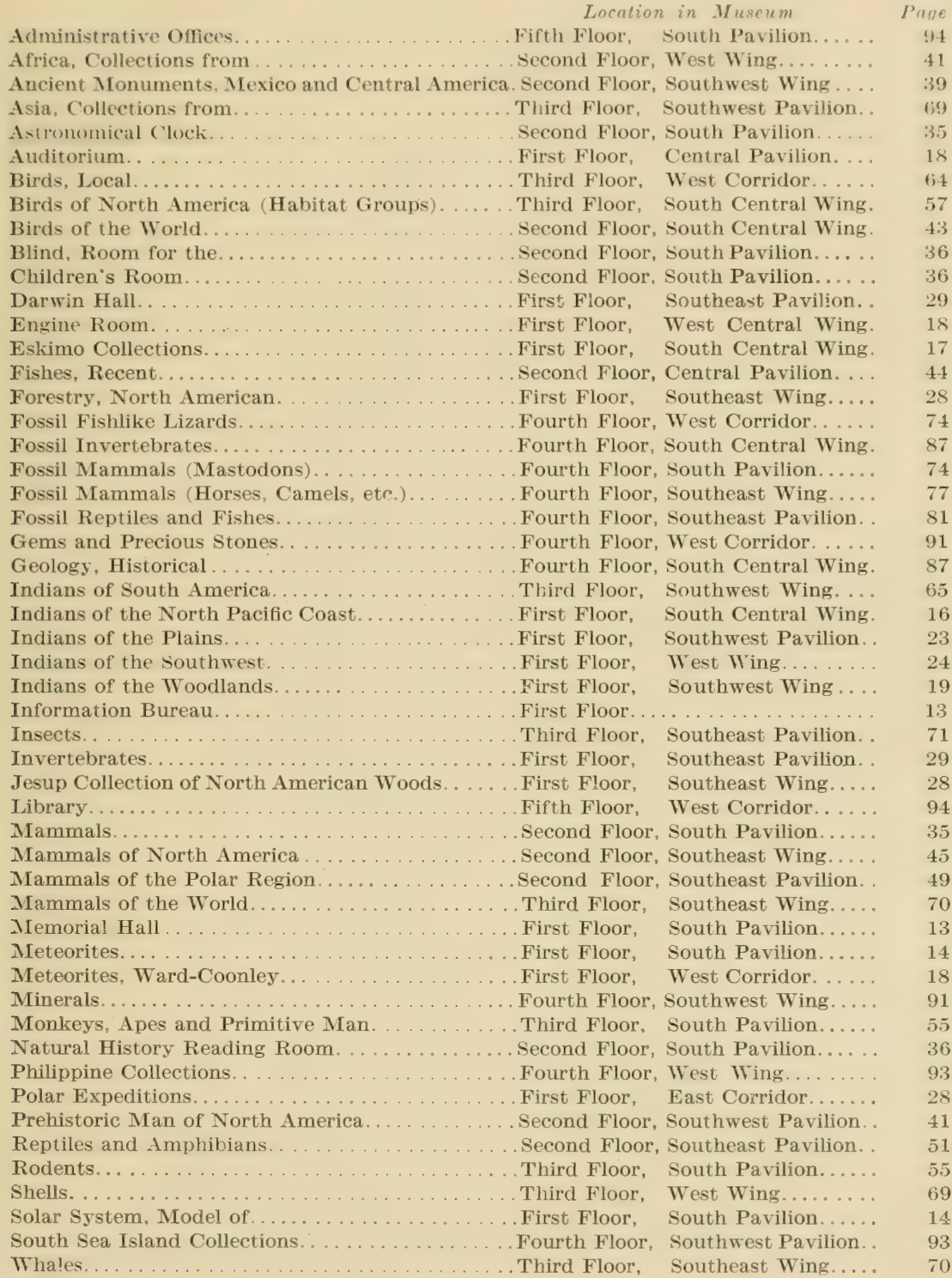




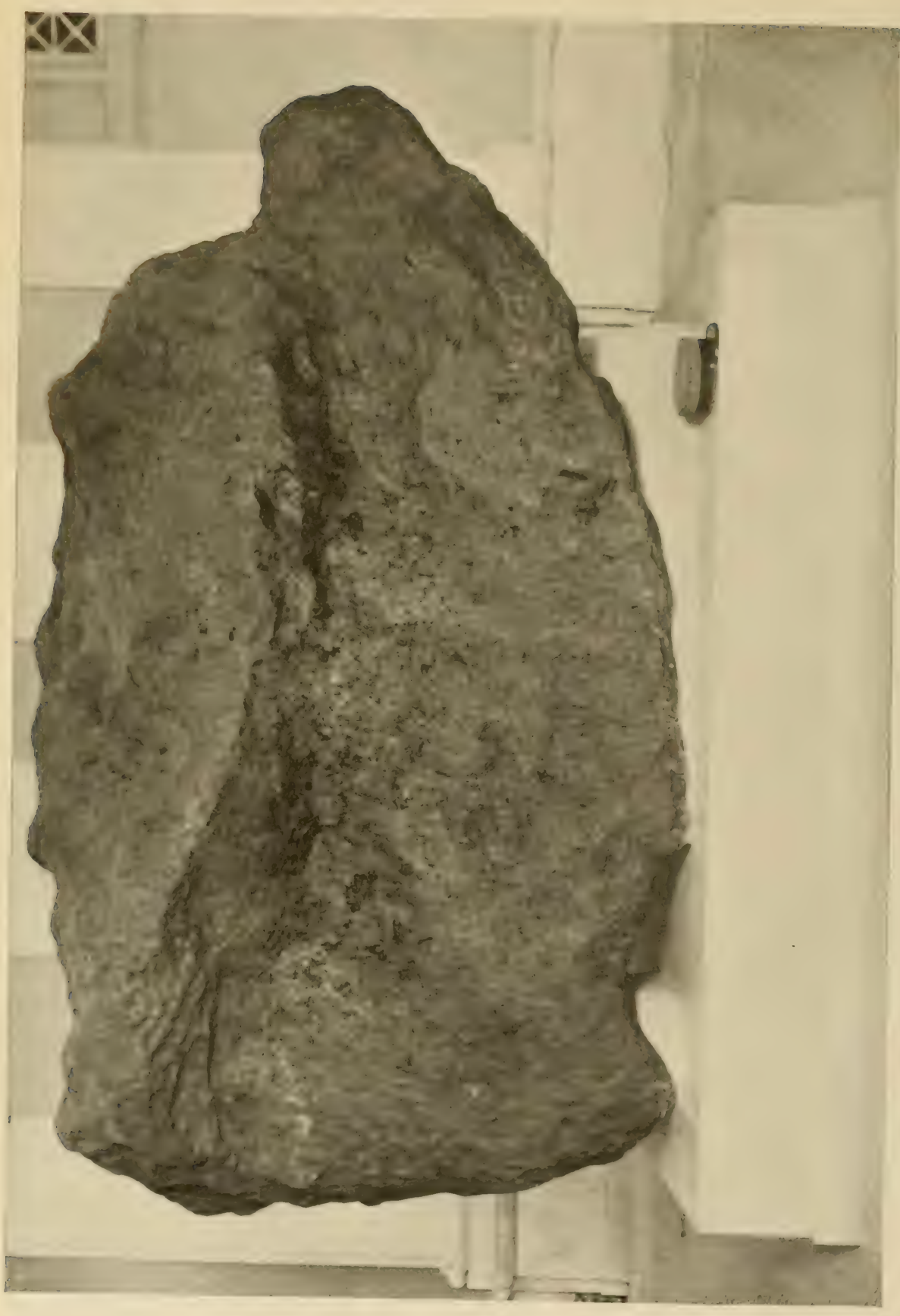




\section{GENERAL GUIDE TO THE MUSEUTI}

\section{INTRODUCTION}

$\mathrm{T}$ HE American Museum of Natural History was founded and incorporated in 1869 for the purpose of establishing a Museum and Library of Natural History; of encouraging and developing the study of Natural Science; of advancing the general knowledge of kindred History subjects and to that end, of furnishing popular instruction. For eight years its temporary home was in the Arsenal in Central Park. The corner stone of the present building in Manhattan Square was laid in 1874 by President L. S. Grant, and in 1877 the first section (South Central Pavilion) was completed.

Location

The Museum is located at 77th Street and Central Park West, and can be reached by the 8 th or 9 th Arenue surface cars, the 6 th or 9 th Avenue elevated to 81 st Street station, or by the subway

Hours of Admission to $72 \mathrm{nd}$ or 79 th Street station. The Museum is open free every day in the year; on week days from 9 A. M. to 5 P. M., on Sundays from 1 to 5 P. M.

The Museum building is one of the largest municipal structures in the City, and has cost approximately $\$ 5,000,000$. The South Façade is 710 feet in length; the total area of the floor space is 470,789 square feet, or about 10 acres, of which 271,886 square feet are open to the public. The building when completed is designed to occupy all of Manhattan Square.

The Museum is under the control of a self-perpetuating Board of TrusAdministra- tees, which has absolute control of all property of the Museum tion and and the entire direction of its activities. The Trustees give Support their services without remuneration.

The Museum building is erected by the City and leased to the Trustees. The Museum derives its chief financial support from four sources:

1. The City, which provides annually an appropriation $(\$ 189,757$ in 1911) for the maintenance of the building and the exhibition of the collections. Such appropriations are not available however for purchase of specimens, carrying on of field work or publication of scientific papers.

2. Endowment, a total of $\$ 2,365,750$ (1911), which yields an annual income of $\$ 109,540$.

3. Membership, there being at present more than 2000 Members each contributing annually $\$ 10$ or more for the support of the Museum. Membership fees total approximately $\$ 25,000$ per year, and are used for the purchase of specimens, for exploration and for publication.

4. Voluntary contributions of Trustees and other friends of the Museum, which are more than $\$ 80,000$ for the year 1911 . 


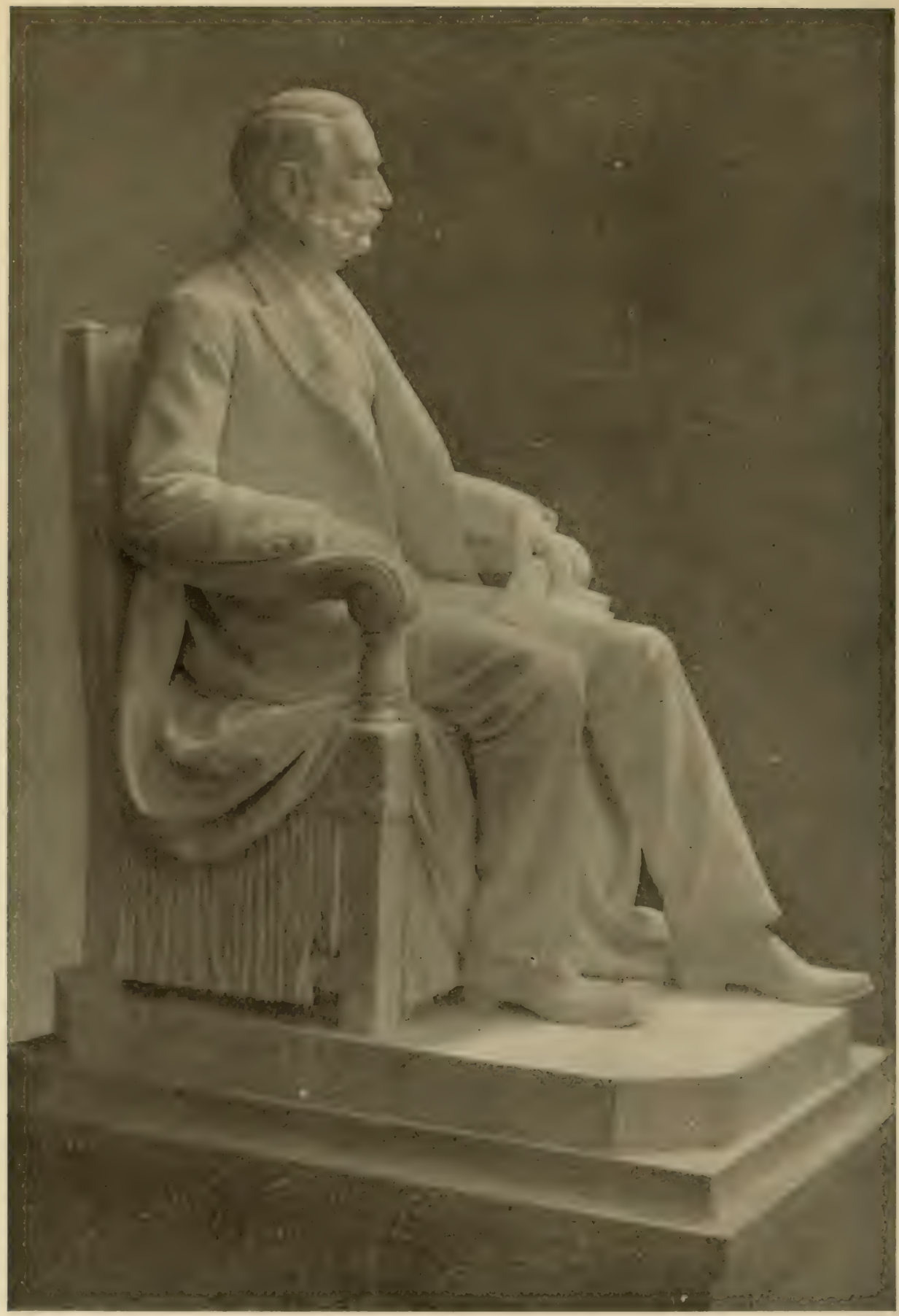

MEMORIAL STATUE OF MORRIS K. JESUP

Mr. Jesup, President of the American Museum of Natural History for more than a quarter of a century, was a staunch supporter of the institution's two aims, to be a great educational institution for the people and also a center for activity in scientiflc research 12 


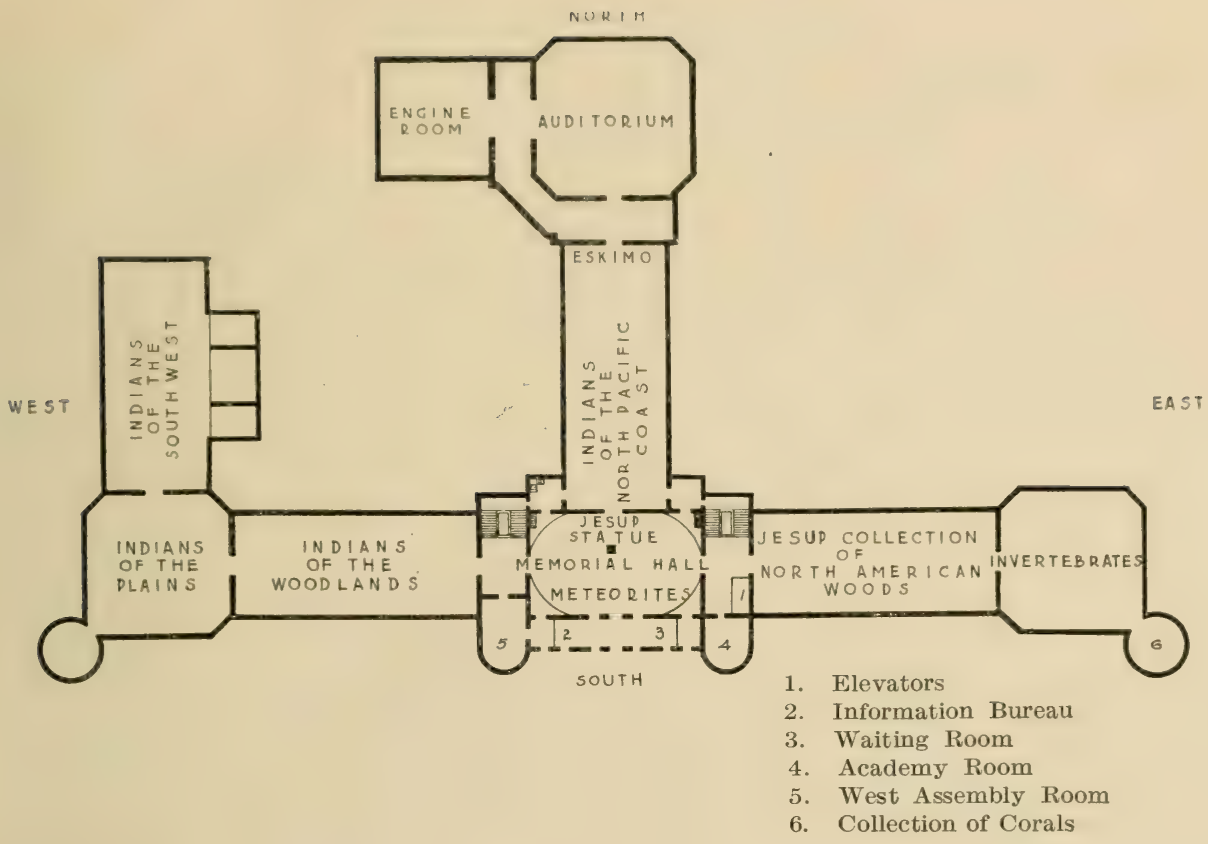

FIRST FLOOR

SOUTH PAVILION

Memorial Hall

The Information Bureau and the Checking Room are at the south entrance. Wheel chairs for children or adults are available without charge. Postcards, photographs, guide leaflets, and Museum publications Information of various sorts are for sale here. On the right and left of Bureau the entrance are small Assembly Halls in which lectures to classes from the public schools of the City are given and where the New York Academy of Sciences and other scientific societies hold their meetings.

From the lobby the visitor first enters Memorial Hall and faces the Statue of Morris K. Jesup marble statue of Morris K. Jesup, third President of the Museum. Mr. Jesup was a founder, trustee and benefactor of the Museum and for twenty-seven years its President. Under his administration and through his liberality the Nuseum made 
rapid progress. This statue of Mr. Jesup was executed by William Couper and was presented to the Museum by the Trustees and a few other friends. The marble busts in the wall niches represent noteworthy pioneers of Amer:can science, and are the gift of Morris K. Jesup. These include Benjamin Franklin, statesman and natural philosopher, Alexander von Humboldt, geographer and geologist, Louis Agassiz, zoölogist, Joseph Henry, physicist, John James Audubon, ornithologist, Spencer Fullerton Baird, zoölogist and founder of the Lnited States Fish Commission, James Dwight Dana, geologist, John Torrey, botanist, Edward Drinker Cope, palieontologist, and Joseph Leidy, anatomist.

Circling this same hall is the collection of meteorites, popularly known as "shooting stars," ranging in weight from a few grains to 36 tons. The Meteorites greater number of meteorites are stony, but the more interesting ones are composed chiefly of iron, while certain meteorites contain both stone and iron. The toughness of iron meteorites is due to the presence of nickel, and the fact that they were so difficult to cut led to the adoption of an alloy of nickel and iron in making the armor plate for battleships. Meteorites have a very definite structure and when polished (see specimens on the right with electric lamp) show characteristic lines which together with their composition are to the expert absolute proof that the specimens are meteorites.

"Ahnighito" or "The Tent" at the left is the largest known meteorite in the world, and was brought from Cape York, Greenland,

Ahnighito Meteorite

Willamette Meteorite by Admiral R. E. Peary. It weighs 36 tons, and its transportation to New York was an engineering feat. Opposite it at the right is the curiously pitted "Willamette" meteorite from Oregon which was the subject of a famous lawsuit. TThe collection of meteorites is fully described in Guide Leaflet No. 26.]

Suspended in the center of the room is a three-inch incandescent globe representing the sun. Standing directly beneath this globe one may see

Model of Solar System suspended from the ceiling other lights representing the four planets of the Solar Sistem which are nearest the sun, and installed in such a manner as to show relative size and distance from the sun, and orbit around the sun. The respective orbits are subdivided into sections representing the solar day, and the relative diurnal position of each planet is shown. The "Signs of the Zodiac" are imbedded in the floor. 


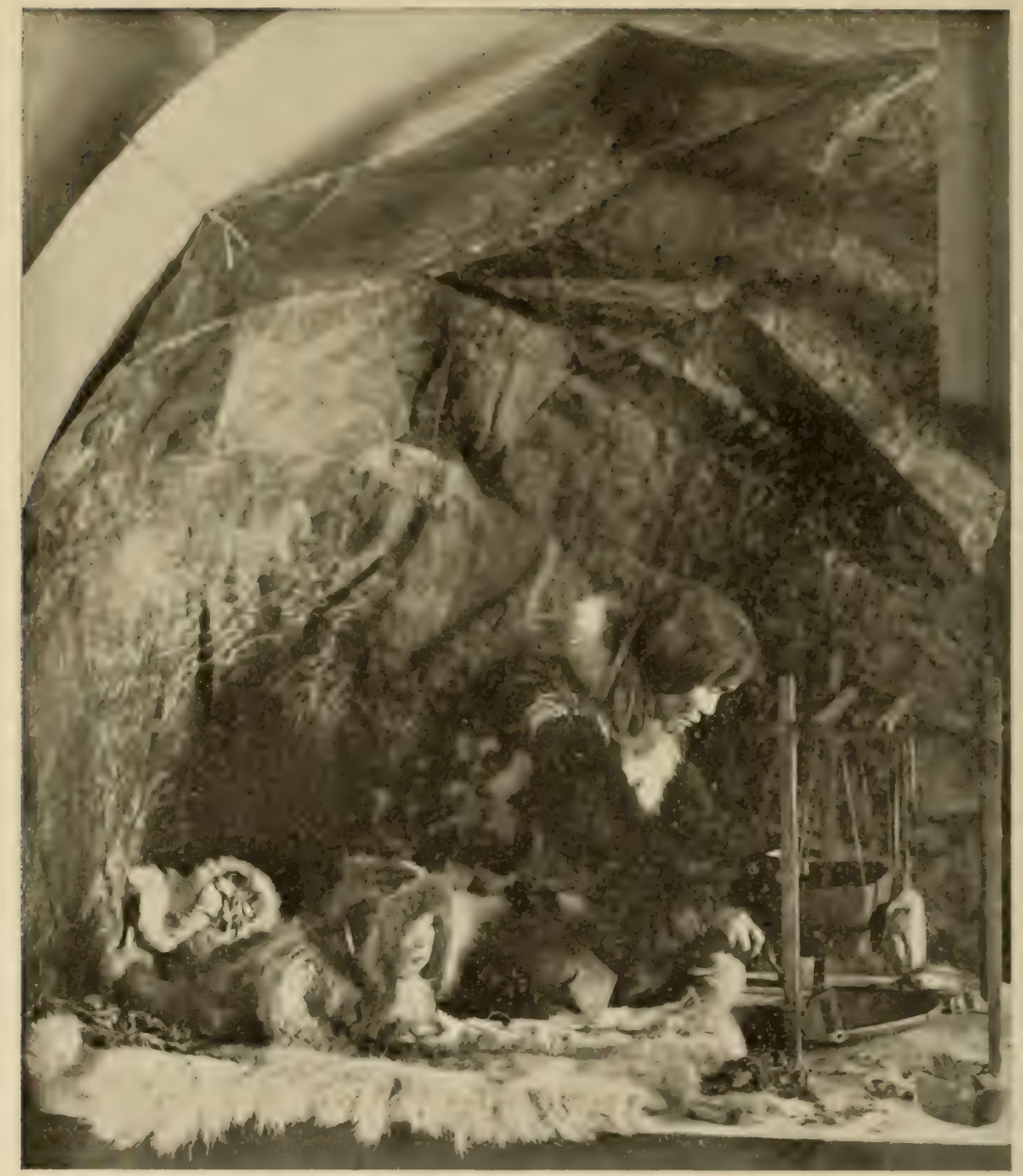

ESKIMO HOME SCENE

There are two notable groups near the entrance to the Auditorium and underneath the Stokes mural paintings of the Land of the Midnight Sun. In one, a home scene within a snow house or "igloo," an Eskimo woman is cooking blubber over the flame from a seal oil lamp. The Museum is rich in Eskimo collections

\section{SOUTH CENTRAL WING}

\section{Indians of the North Pacific Coast}

North of Memorial Hall, that is to the rear of the Jesup statue, is the

Indians of North P'acific II all where are displayed collections illustrating British the culture of the Indians of the Northwest Coast of America Columbia and also of the Eskimo. These collections are arranged and Alaska geographically so that in passing from south to north through the hall the visitor meets the tribes in the same sequence that he would in traveling up the west coast of North America. 
The most striking object is the great Haida Canoe in the center of the hall with its party of Chilkat Indians Haida Canoe celebrating the rite of the "potlatch." The potlatch is the great "giving ceremony," common to all the coast tribes, when individuals and families gladly impoverish themselves that the dead may be honored, the emblem of the clan exalted and social standing recognized or increased, while underlying the potlatch as a social function is a deep religious fervor in the worship of ancestry and communion with the dead. At the stern of the canoe, which is represented as approaching the beach, stands the chief or "medicine man," who directs the ceremony. The canoe is a huge dugout made from a single tree, is 64 feet long and 8 feet wide and capable of carrying 40 men.

Against the pillars and walls of the hall are many Totem Poles house posts and totem poles with their Totem Poles grotesque carvings; the latter may represent either the coat of arms or family tree, or they may illustrate some story or legend connected with the family. The Haida Indians together with the Tlingit are recognized as superior to the other Indian tribes along the Northwest Coast of North America. They are divided into a number of families with various crests for each family and grouped into two main divi-

\section{Chilkat \\ Blankets}

sions, the Ravens and the Eagles. The Tlingit are makers of the famous Chilkat blankets, of which the Museum possesses an exceptionally fine collection. Among some of the other tribes there is little wool weaving, the clothing consisting of shredded and softened inner tree bark braided and matted together. The Indians of this region are preëminently a woodworking people, as is manifest in the exhibit. Religious ceremonies and the

Religious Ceremonies wearing of masks generally supposed to aid the shaman or priest in curing disease, were customary among most of the tribes. The masks represented guardian spirits and by wearing them the shaman impersonated these spirits.

The north end of the hall is devoted to Eskimo collections. The cases on the right show the manner of dress, method of transportation, etc., also cooking

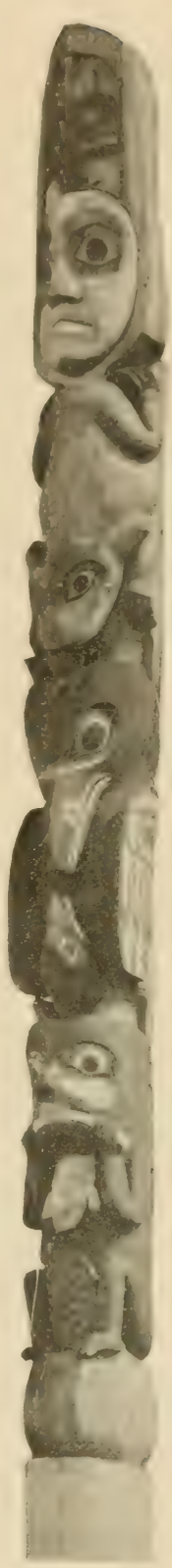

Modern totem pole at Wrangel, Alaska. Many totem poles are huge cedar carvings so old that the Indians themselves have forgotten their meaning 
utensils and bonework. Notice how many of the utensils, weapons and clothing are made from the skin or bone of the seal, walrus and other Arctic animals. The case marked "Eskimo Woman Cooking" shows a

\section{Eskimo}

Collections section of the interior of a snow hut or igloo lined with sealskin, the mother preparing the food in a primitive stone vessel, heated by flame from seal oil in the stone lamp below. The opposite case shows an Eskimo woman fishing through the ice. She has formed a windbreak with blocks of ice. The fish-rod and hook, and the long ladle are made of bone, and with this latter she keeps the water in the hole from freezing over while she is fishing.

The mural decorations of Aretic scenery are by Frank Wilbert Stokes,

Mural and the legend depicted on the main canvas over the door is

Decorations given in full in Guide Leaflet No. 30; the mural decorations illustrating the industries of British Columbia and Alaska are by Will S. Taylor.

The doorway at the north end of the hall leads to the Auditorium which has a seating capacity of 1400, and is equipped with two screens, 25 feet Auditorium square, for stereopticons. Free public lectures are given here Tuesday and Saturday evenings from October to May under the auspices of the Board of Education. There are also free lectures on public holidays, and special lectures for Members of the Museum as well as lectures for school children.

At the end of the corridor is the power room where may be seen demonPower Room strated the transformation of the potential energy of coal into heat, light and motion.

[Return to the Jesup Memorial Statue.]

\section{WEST CORRIDOR}

To the right or west of the Jesup statue are three halls devoted to Ward-Coonley Indian collections. To reach these the visitor passes Meteorites through the West Corridor containing the Ward-Coonley collection of meteorites which numbers 603 "falls" and is the most complete collection of meteorites in the world. 


\title{
SOUTHWEST WING
}

\author{
INDIANS OF THE WOOdLANDS
}

The first hall to the west contains the collections pertaining to the Indians of the Woodlands. Indians of These Indians include all tribes $\begin{array}{ll}\text { the Wood- } & \text { east of the Mississippi and are } \\ \text { lands }\end{array}$

therefore those connected with the very early history of the country. In the eastern section of this hall are the New York State Indians of whom the Iroquois are the most important because of their superiority in organization and power.

The League of the Iroquois, or the Five Iroquois Nations, comprised the Mo-

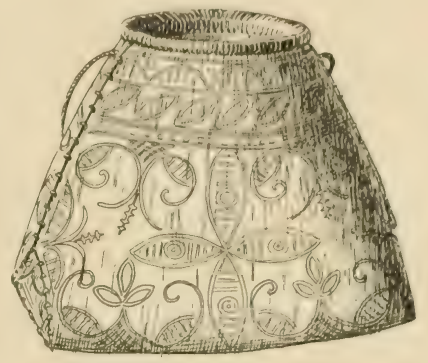

Carved birch bark kettle of the Penobscot Indians.

daga and Cayuga, later the Tuscarora, when it was styled the Six Nations.

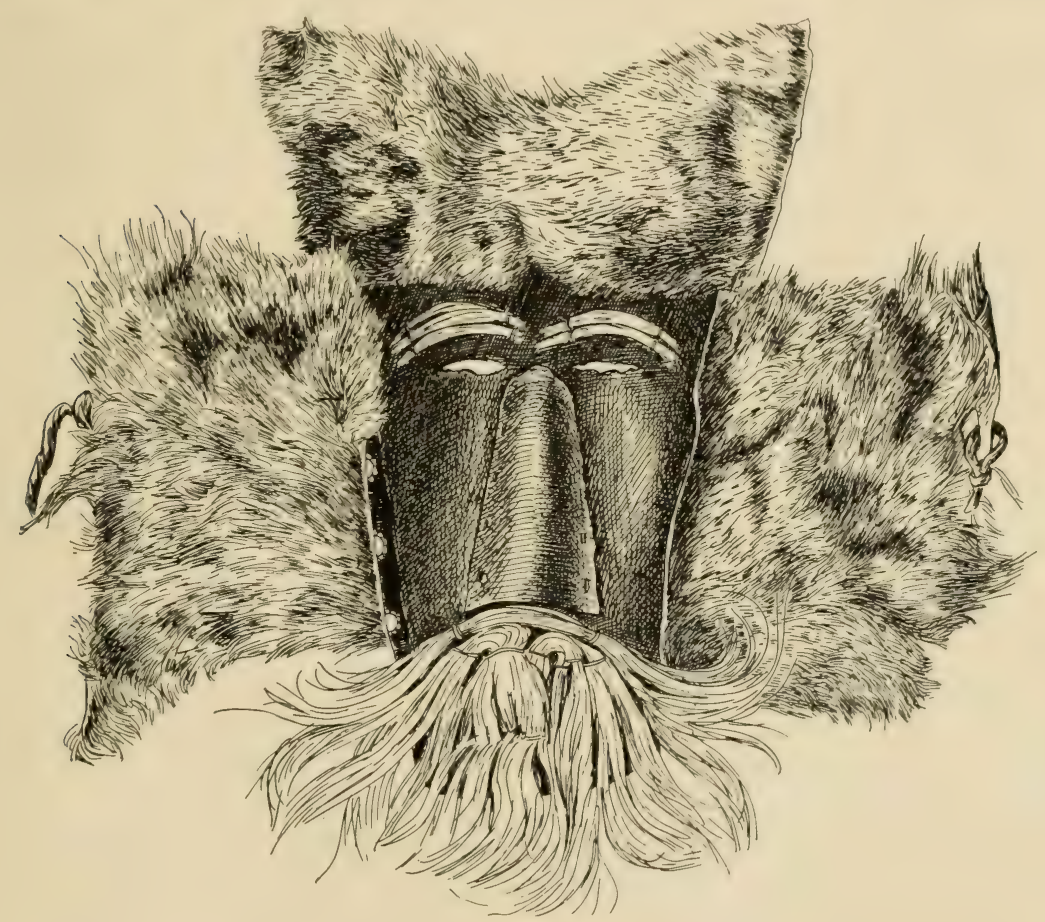

Cherokee mask, Indians of the Woodlands, North Carolina. Such masks were worn by members of "False Face" Societies supposed to be able to counteract the work of evil spirits and to heal sickness 
This league was formed probubly as early as 1.539 and with the purpose, as its founders boasted, of hringing peace and breaking up the spirit of perpetual warfare. It is interesting to note that the Indians recommended it as a model to the colonies. The Oneida Indians were the only members of this league who, as a tribe, adhered to the colonists in the war of the Revolution.

In the wall case on the right are shown the dress, occupations and dwellings of the Iroquois. A life-size model of an Iroquois representing a messenger is holding out a belt of wampum. This wampum, made chiefly Wampum of the shells of the "quahog" or common hard clam of our wampum markets, was utilized in various ways: It was greatly prized as an ornament and as trimming on garments; was an important feature in religious ceremonies and festivals, being the token by which the Indians confessed and took oaths; and was the object by which public: transactions were commemorated. Wampum was not used as currency however, the Indians having no standard of value until they found it in our currency, but it did come nearer currency than any other kind of property, and when sold to white settlers the strings were counted and reckoned at half a cent a bead. The woman in the right of the case is pounding corn in a primitive mortar. (Corn and tobacco are our legacies from the Indian.) The matrons of the Iroquois owned their own property in distinction from their husbands; they sat in council by themselves and had the right to terminate a war.

On the left is a collection of grotesque masks. These were worn by "False the False Face Societies. The Indians were very superstitious Faces" and believed in the existence of demons or evil spirits who were without bodies, legs or arms, and possessing hideous faces only, were characterized as "false faces." There eventually grew up a society calling itself the "False Face Band" whose members were supposed to have power to counteract the evil done by these demons and to possess the capacity to heal sickness. Pictures by De Cost Smith illustrating this society are on exhibition in this hall.

The earliest Indians of the vicinity of New York City are represented Local by the archæological collections in the first alcove on the left. New York Here will be seen remnants of their crude pottery, weapons, Indians cooking utensils, and various implements made of stone, wood or bone, collected chiefly from burial sites on Manhattan Island, Staten Island and Long Island. On the top of one of the cases is a portion of an original dugout canoe which was excavated in Oliver street in 1906 when a telephone eonduit was being laid. This canoe and a large earthern pot are among the very few good specimens that have ever been found representative of New York City Indians. 
The collections of the remaining tribes of the Woodland Indians are in process of installation and will be treated in the following order: On the right or northern side of the hall, the ( herokee, seminole, Menomini, siuk and Fox, and Winnebago tribes; on the left or southern side of the hall, the Delaware, Ojibwa and Cree tribes. The Seminoles have never been seminole entirely concuered. They moved into Florida and have taken up their abode in the Everglades, hostile to the white man whom they will not allow to enter their domain. This exhibit is one of the three existing collections from Seminole Indians.

Among the Menomini specimens there is an excellent collection of Menomini medicine bags, porcupine quillwork and a buffalo skin headdress worn by a noted chief Oshkosh. The Menomini have always been friendly to the Americans.

The Winnebago in Wisconsin claim to have built the mounds representWinnebago ing animals in the neighborhood. The Winnebago and the Delawares are linguistically related.

Examples of clothing are shown in the collections of the eastern Cree Cree who live in Labrador. Among these examples is a twisted rabbit skin, the Baby Bunting skin of fable. The garments of the eastern Cree are painted rather than worked with beads.

The Ojibwa made maple sugar. Examples of their picture writing on Ojibwa strips of birch bark, descriptions of ceremonies and songs, are on exhibition; also a number of birch bark baskets. Hiawatha was a member of this tribe.

Among the Delaware collections is a doll that was worshipped by this Delaware tribe as the guardian of health. Indians of the vicinity of New York City resemble this tribe more nearly than any other. The Indians of Manhattan and vicinity are described in Guide Leaflet No. 29.

\section{SOUTHWEST PAVILION}

\section{Indians of the Plains}

The collections of the Indians of the Plains will be found in the hall adjoining. These Indians comprised the tribes living west of the Mississippi and east of the Rocky Mountains as far south as the Valley of the Rio Grande and as far north as Saskatchewan. They include

Indians of the Plains the Plains Cree, Dakota, Crow and Blackfoot shown on the left of the hall, and the Mandan, Pawnee, Kiowa and Cheyenne on the right. All these tribes were dependent on the buffalo, so much so that they have sometimes been called the "Buffalo 


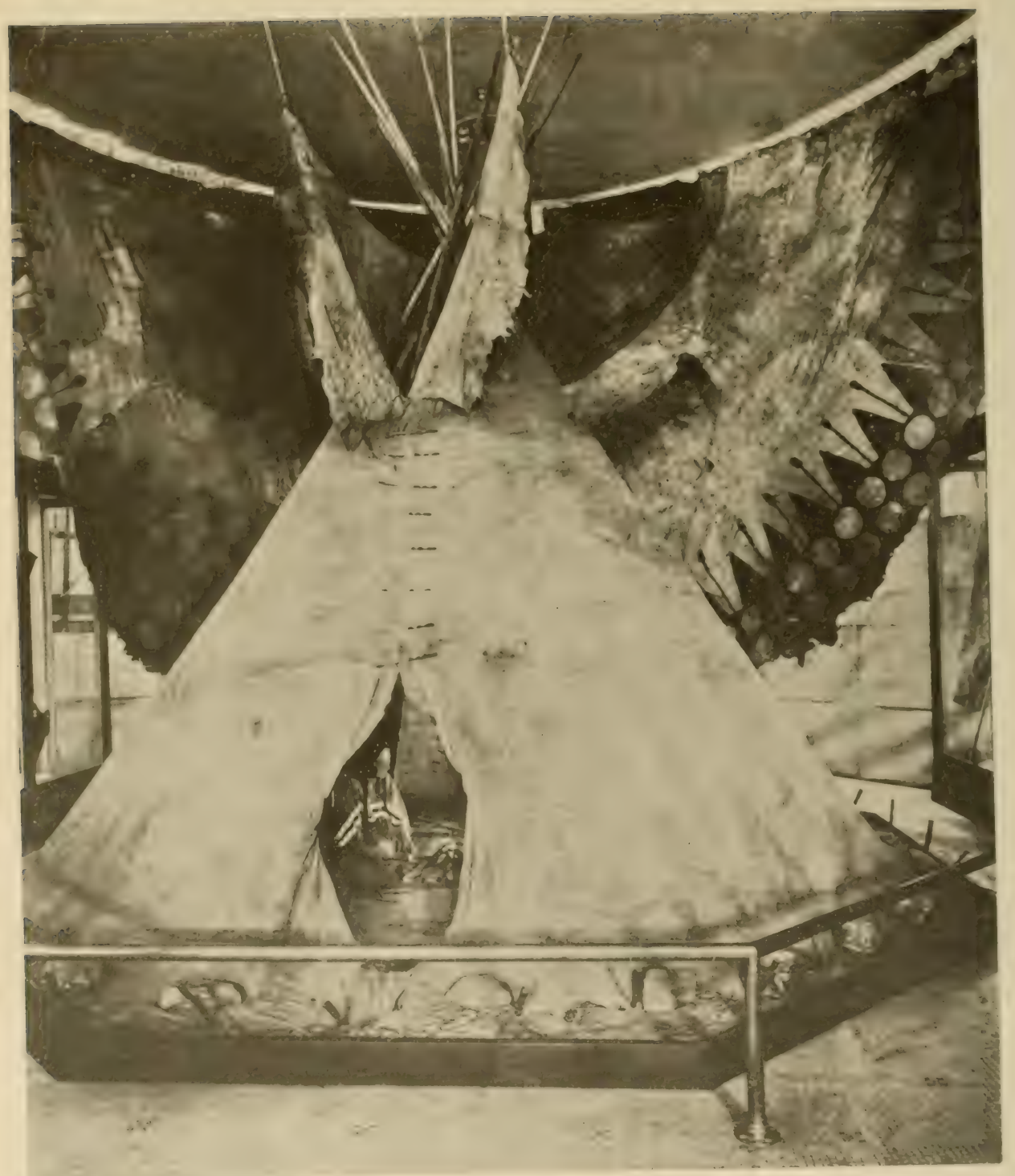

A MEDICINE MAN'S TIPI, OBTAINED IN MONTANA, 1903

The interion anged in household tasks, a tobacco board and pipe are in place for guests, the ashes of the family altar tell of many incense-sprinkled coals that have burned down there 
Indians." Buffalo flesh was their chief food, and buffialo skin they made into garments. A buffalo paunch was used for cooking and buffalo horns were made into various implements of industry and war. The spirit of the buffalo was considered a powerful ally and invoked to cure sickness, to ward off evil and to give aid in the hunt. Wherever the buffalo herds led the way, the Indians moved their tents and followed. With the extermination of the buffalo the entire life of the Plains Indians was revolutionized.

In the center of this hall is a genuine Blackfoot Indian tipi with a painting of an otter on

\section{Blackfoot}

Tipi

assistance from the otter.

There were numerous societies among the Plains Indians which included practically all

\section{Societies} grown Indians. A special dance these societies. The costumes worn on such occasions are shown in this hall. There were other dances connected with their religious

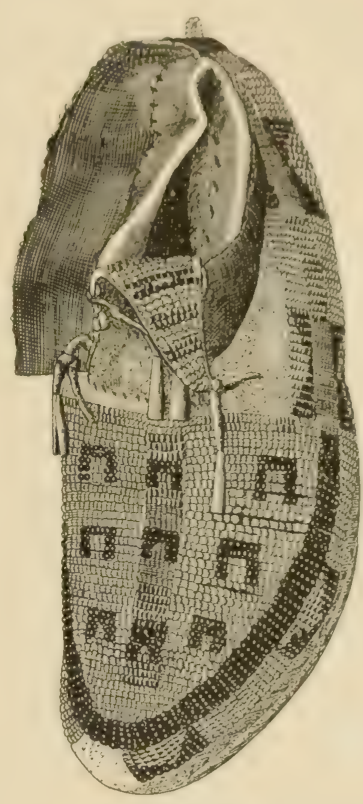

A beaded moccasin from the Indians of the Plains, (Gros Ventre) ceremonials, the best known and most important of which is the sun dance Sun Dance illustrated by a model at the left of the tipi. The sun dance was held annually in the early summer in fulfillment of a vow made during the preceding winter by some member of the tribe who wished a sick relative to recover. The dance involved great physical endurance and excruciating self-torture, lasting three days, during which time the dancers neither ate nor drank.

At the entrance to the tower room is a genuine medicine pipe, held in

\section{Medicine}

Pipe awe by the Indians and dearly parted with; also the contents of a medicine pipe bundle. The contents of another medicine bundle, belonging to a learned man of the tribe (medicine man), together with the headdress which he wore when visiting the sick, is in a case near.

The Plains Indians are noted for their picture writing on skins and for their quillwork which has now been superseded by beadwork. [See Guide Leaflet No. 15.] 


\section{WEST WING}

\section{INDiANS of THE Southwest}

$\mathrm{T}^{\mathrm{N}}$ 11: hall to the north is deroted to the Indians of the southwest, neighbors of the Plains Indians. They comprise those tribes west of the eastern border of the Rocky Mountains living in the southcrn part of Itah and colorado, in .rizona, in New Mexico and in Northern

Indians of the Southwest

Mexico. The hall is divided into two main sections: on the left are the sedentary Indians - the Rio Grande Pueblo, the prehistoric Pueblo Bonito, the Hopi, the prehistoric Cliff Dwellers and the Zuni; on the right are the nomadic Indians - the eastern Apache, Apache, Navajo, P'ima, and the Indians of Northern Mexico. The sedentary Indians were peaceful and agricultural, made pottery, dwelt in adobe houses and lived from age to age in one location. The nomadic tribes were warlike and hunters, made baskets, lived in tipis of buffalo skin and brush, and mored from place to place since they would not live in an adobe where death had occurred. At the entrance to this hall are models of Indian villages at Acoma and De Taos. In examination

Models of Pueblo of these will give the visitor a correct idea of the manner of Villages of living, the character of the houses, churches and kivas, Acoma and chanted Mesa" so surrounded by mystery. Material colDe Taos lected from the Acoma tribe is found farther on in the hall and is described on p 26.

On the left in a wall case are shown samples of pottery. This industry was foremost among the sedentary Indians because the question of transRio Grande portation did not have to be considered. Their food proPueblo ducts of corn, beans, squash, cornmeal, bread, etc., are in the next case; and examples of their ornaments, costumes and war implements are shown farther on.

The Hyde collection of very distinctive black and white pottery in the wall cases on the west is from the prehistoric Pueblo Bonitos. In an adjoinPrehistoric ing case is pottery from Rio Tuleroda, representing a preTribes historic and absolutely unknown tribe. Prehistoric inlaid work and remarkable work with turquoise in other cases near belong to the Pueblo Bonito tribe. Sandals, basketry, pottery, bags made of the yuca plant, examples of weaving, and two mummies are from the prehistoric Cliff Dwellers whose houses are represented by models along the wall. A most extraordinary fragment of a blanket remarkable for its texture and design is in a glass frame in one of the cases. 


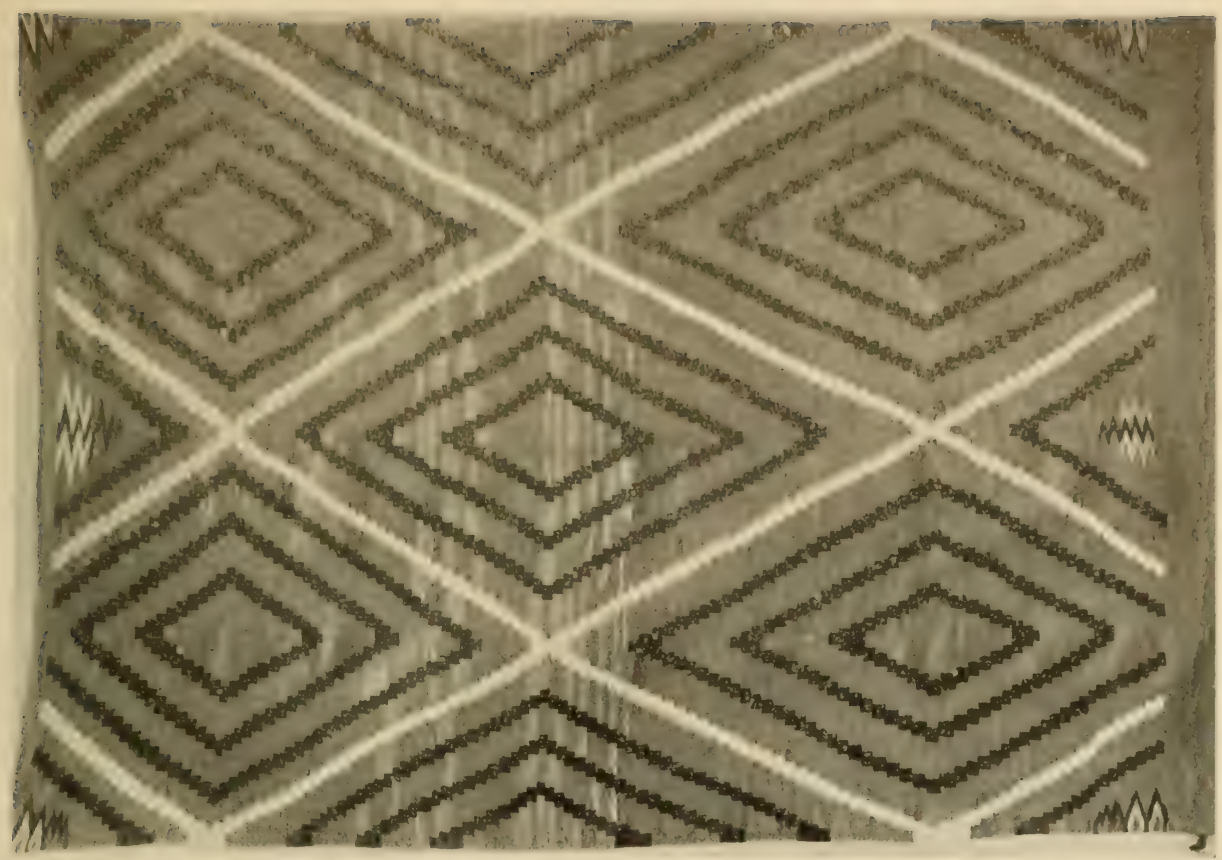

An attractive Navajo blanket from the Museum's valuable collection. The Navajo Indians of the Southwest are a wealthy pastoral people and the only Indian blanket-makers of North America.

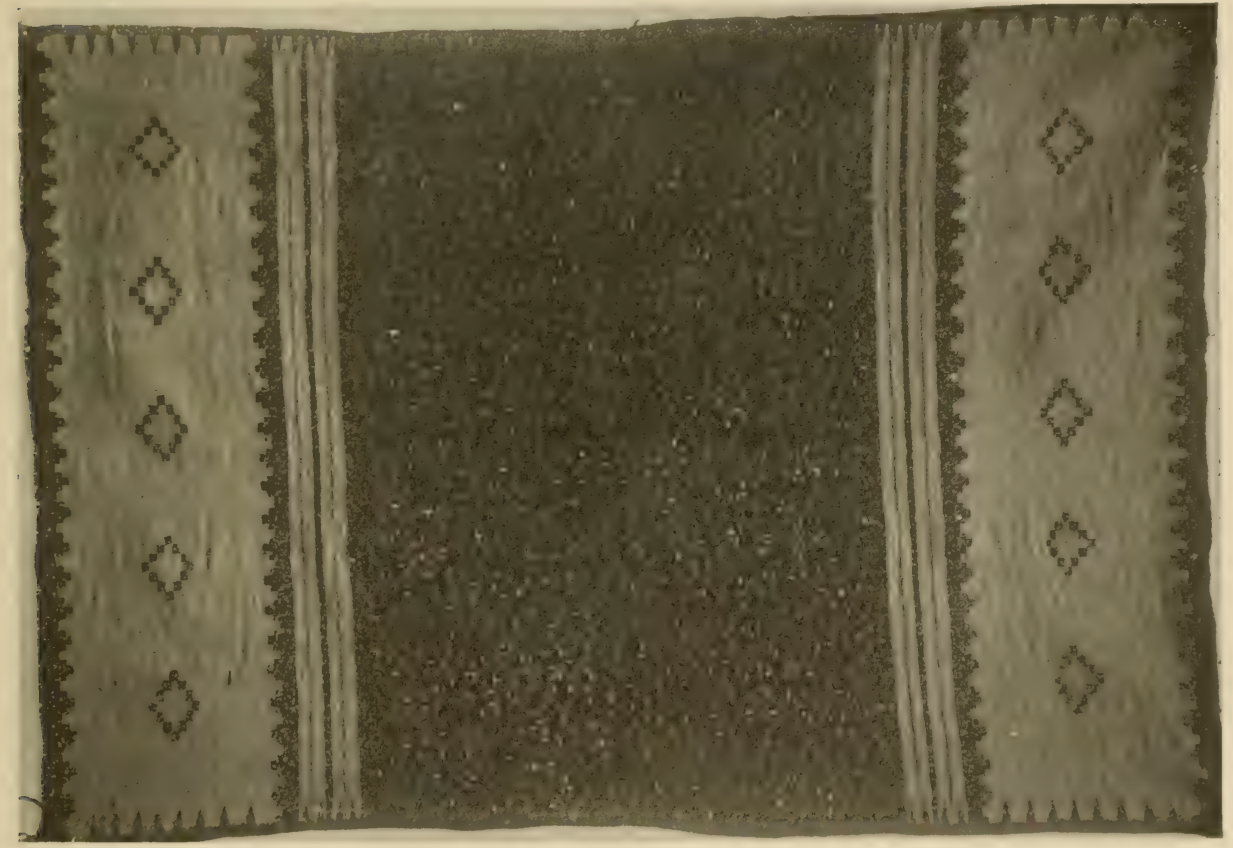

Navajo woman's blanket of black and bayeta red. The woman's dress is made lby sewing together two blankets along the sides and one end, leaving openings for head and arms. Bayeta blankets, not made since 1875, are the oldest and most valuable of Navajo weaving; each contains some amount, small or large, of red yarn ravelled from Spanish military uniforms 
The Hopi are the people of the snake dance. One case contains the Hopi costume and insignia used in the dance, and another ceremonial placques.

The Zuni were first visited and described by the Spanish in 1540. For Zuni three hundred years and over they have resisted the inroads of ('hristianity and in spite of missionaries and churches, they still maintain their own religious ceremonies. Some of their ceremonial masks and idols are in a near case. The wearing apparel and pottery of the Acoma and /uni are in the northern part of the room. In one case a collection of saddles, plows and various implements is evidence of Spanish influence on the Indian.

Continuing around the hall, the visitor comes to the case containing Mexican the serapes, blankets of wonderful design and texture made Indian by the Mexican Indians, particularly near Saltillo. 'They were made for the wealthy Spaniards and were worn as ponchos or simply thrown over the shoulder. A serape is made at the present day, but it is quite different from the old-time serape. One case holds a model of a Mexican Indian woman weaving a serape and a man mending an arrow.

The Pima race, next in order in the hall, extends into Mexico. These Pima are desert people, using the giant cactus, century plant and juniper berries for food.

To the Navajo Indian is justly acceded superiority in the field of weaving. Narajo blankets are of unusual beauty and design and are Navajo made from the wool obtained from their own sheep (introduced into the region by the Spaniards) which they herd in great numbers. To-day the blankets they weave are almost all sold, while they buy machinemade blankets for their own use. One case contains valuable bayeta blankets, named such because the red in them was obtained from ravelled "bayeta" or flannel from Spanish military uniforms. The silversmith industry was introduced among these Indians by the Mexicans, and the buckles, bracelets and other ornaments exhibited are made from the Mexican silver dollar. In an adjoining case are displayed the tools used in this work.

The Apache of the Southwest were not as warlike as the eastern Apache, Apache but lived on their own land and wove and made baskets. The eastern Apache raided the country belonging to the Plains Indians for buflato, swooped down, captured their prey and returned before they were overtaken by their furious pursuers. The dress, ornaments and implements of the eastern Apache are similar to those of the Plains Indians. Their tipis also correspond in being made of buffalo skin. The case against the south wall contains examples of basketry, the pastime 


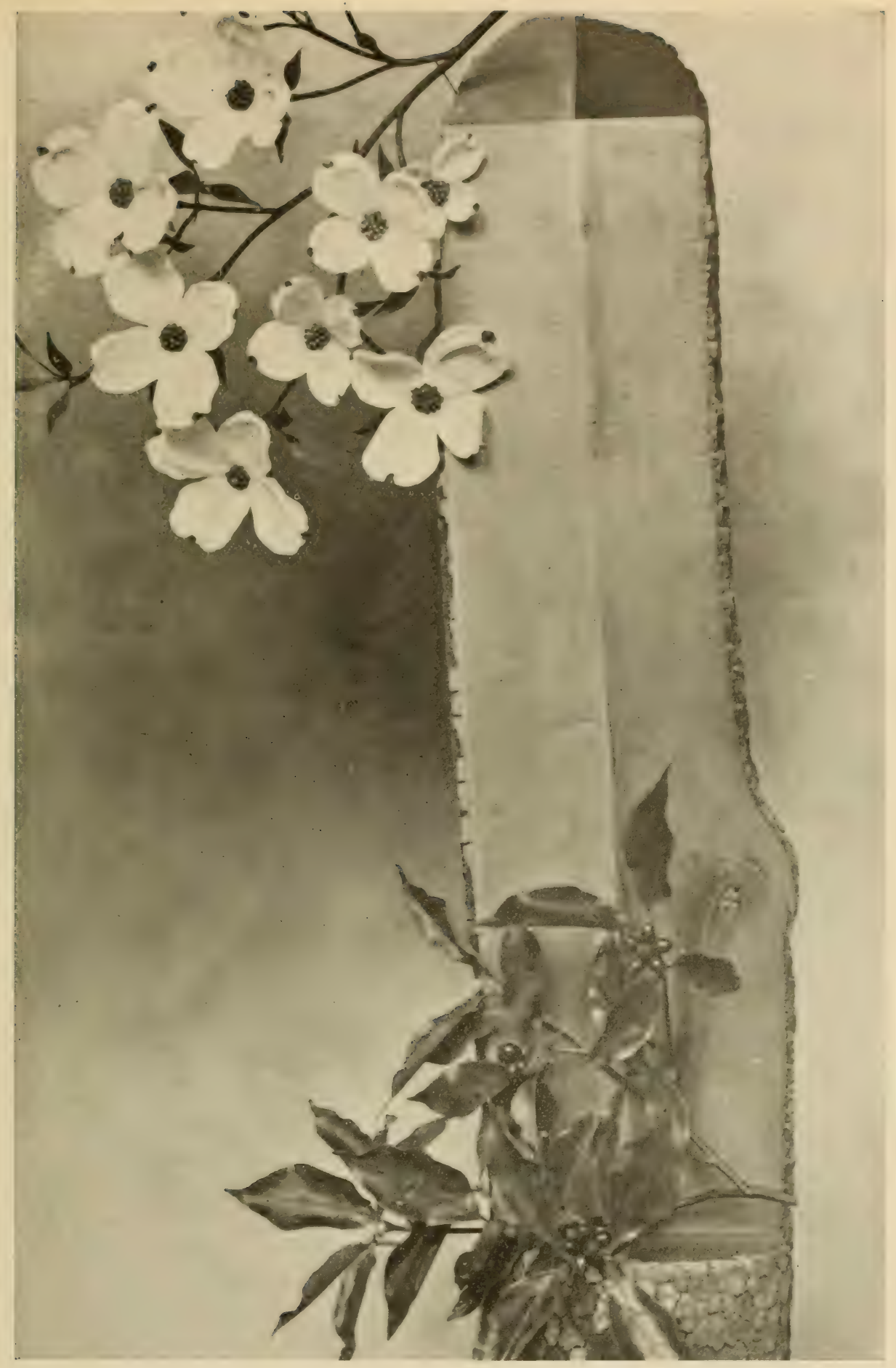

FLOWERING DOGWOOD IN THE FORESTRY HALL

Each of the five hundred species of trees in North America is represented by a section of trunk five feet long, some of a diameter not found in the country's forests to-day. Many of the specimens are accompanied by wax models of leaves, flowers and fruits accurately reproduced from life 
and industry of these moving peoples. FFor data on the Basket Makers of Southeastern Utah see Guide Leaflet No. 6.]

[Return to the Jesup Statue.]

\section{EAST CORRIDOR}

\section{Polar MaPs}

Leaving the statue on the left and "Willamette" meteorite on the right and going east the visitor enters the corridor where the elevators are located (East Corridor). Here will be found maps of the north and south Polar Expe- polar regions showing the routes of explorers. On the wall ditions by the north polar map are the sledges used by Admiral Peary in his last three expeditions in search of the North Pole. The Morris K. Jesup sledge which the Admiral used in his success-

Peary

Sledges ful polar expedition is the one nearest the entrance. The various sledges in their differences of style show the persistent effort made by Admiral Peary to bring the sledge up to its greatest possible usefulness. That he was successful on his last trip was in part due to the final modification. [A history of the south polar expeditions is given in Guide Leaflet No. 31.]

\section{SOUTHEAST WING}

\section{Jesup Collection of North American Woods}

To the east of the elevators is the Hall of North American Forestry containing the Jesup Collection of North American Woods, a nearly complete collection of the native trees north of Mexico, presented to the Museum by Morris K. Jesup. The specimens show cross, longitudinal and oblique sections of the wood finished and unfinished, and the labels on the

Jesup Collection of North American Woods specimens give the distribution of the species, the characteristics of the wood and its economic uses. The trees are grouped hy families and the location of each family will be found on the floor plan at the entrance of the hall. The reproductions of the flowers, leaves and fruits in natural size are instructive. This work is done in the Museum laboratories. Note the character of forests as shown hy the transparencies. [For fuller information in regard to this hall see Guide Leaflet No. 32.] 


\title{
SOUTHEAST PAVILION
}

\author{
INVERTEBRATES
}

At the extreme east is Darwin IIall, devoted chiefly to the invertebrate animals (those which do not possess a backbone). The installation in the alcove cases is designed to give a synopsis of the Animal Kingdom and the Synoptic relationships existing between the various groups. Passing Series around the hall from left to right, the progression is from the lowest forms of animal life, the one-celled Protozoa, to the highest and most complex forms of animal life, the Primates, including man. The distinctive characteristics of each group are fully described on the alcove and case labels. Many of the invertebrates, particularly among the lowest forms, are so small and their structures are so minute, that they can be seen only by the aid of a magnifying glass. In such instances the specimens are represented by skilfully prepared models in glass and wax showing the animal many times enlarged. Thus the visitor may obtain an idea of the form and structure of these animals which in spite of their small size have in so many instances such a vital influence on the life of man.

This alcove contains the lowest forms of animal life. All are singlecelled individuals. They are found in stagnant water, and the ocean bottom

\section{Alcove 1 in many \\ Protozoa localities is covered}

with them. The specimens exhibited in this alcove are models, some of which are enlarged more than a thousand diameters.

Sponges are of two kinds. Those with skeletons or supporting structures of silica (i. e.

\section{Alcove 2 flint) and Sponges those with skeletons} of horn. The sponges

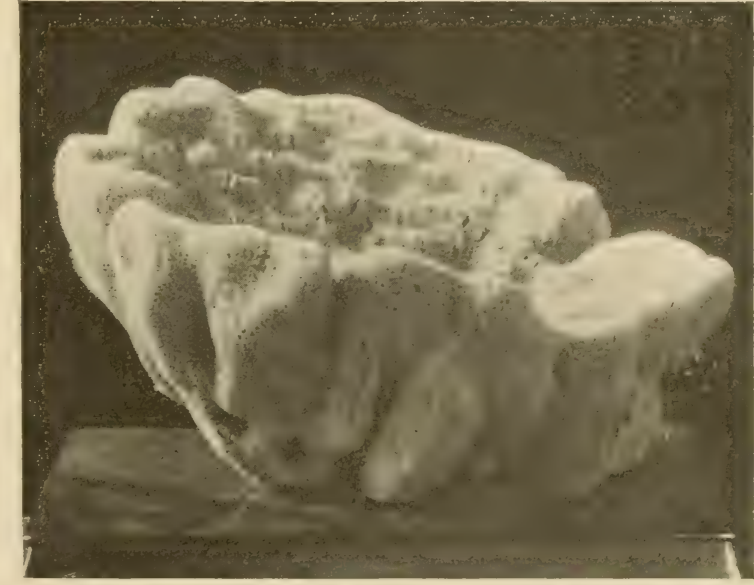

European commercial sponge comparable with the Florida yellow sponge or "Hardhead." The sponge industry in both the Mediterranean and the Bahama region is almost destroyed by careless methods, and conservation must be practiced here as in other of the world's resources 


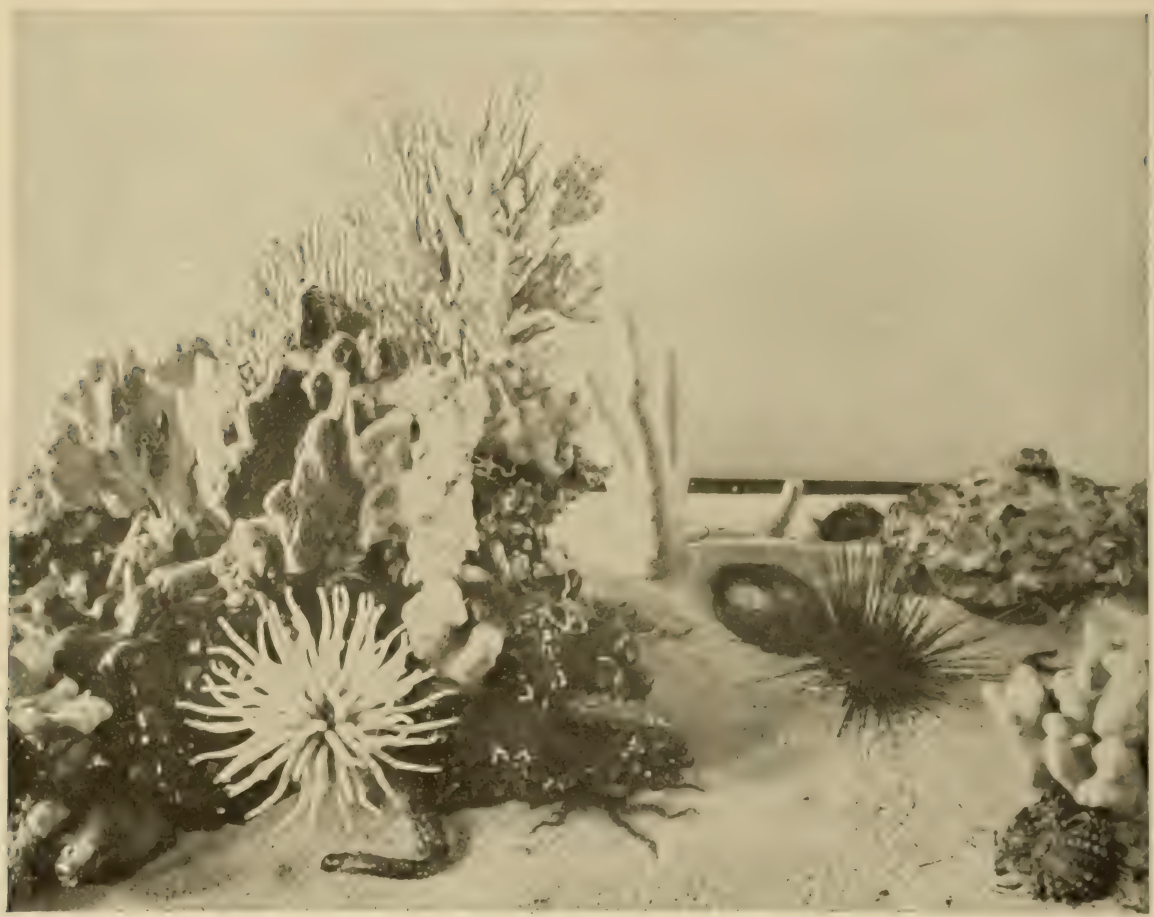

Marine Habitat Group. A community of starfishes, sea anemones, sea urchins, corals and sponges as seen below the edge of a coral reef in the Bahamas

of commerce belong to the latter class. In the specimens exhibited the skeleton only can be seen, the living tissue having been removed. Many of the glass sponges are very beautiful in design. Sponges range in size from the tiny Grantia of the New England coast to the gigantic “Neptune's goblets" found in the eastern seas. This alcove contains certain specimens whose tissue is represented in wax artificially colored to show the natural coloring of sponges, which varies from the bleached yellowish color commonly seen to deep brown or black, or yellow and red, in varying shades.

In Alcove 3 are shown coral animals and their relatives: plant-like Alcove 3 hydroids which often are mistaken for sea moss, but which Polyps really are a series of polyps living in a colony; jellyfishes with their umbrella-shaped bodies and long streaming tentacles; brilliant colored sea anemones, sea fans and sea plumes; the magenta colored organ-pipe coral, and the precious coral of commerce. Coral polyps are the animals that build up the coral reefs (there is no coral "insect").

The best known species in this group is the tapeworm, whose develop-

Alcove 4 Flatworms ment and structure are accurately shown by the models in the central case. As will be seen, its structure is more complex than that of preceding forms. 


\begin{abstract}
Alcove 5 These are for the most part parasitic, living in the digestive Round- canals of mammals. The most familiar is the common worms roundworm or stomach worm, Ascaris, of which an enlarged
\end{abstract} model is exhibited.

The wheel animalcules comprise many exquisite and grotesque forms, Alcove 6 some of which construct tubes of gelatinous substance, sandRotifers grains, etc. A few of the species are parasites, but most of them live a free, active life. They are aquatic, more abundant in fresh water.

The sea-mats in Alcove 7 are plant animals which lead the colonial Alcove 7 Sea-mats form of life. The majority of the species are marine, although alcove superficially resemble
closely related to the worms and starfishes a few occur in fresh water. The lamp shells shown in this alcove superficially resemble clams, but by structure are more

Alcove 8 is occupied by the starfishes, the sea urchins, sea cucumbers Alcove 8
Starfish and sea lilies. The starfish is the pest of the oyster beds as it feeds on oysters and destroys them in large numbers. Starfish have the power of self-mutilation, i. e. when handled or attacked they are able to drop off an arm and later regenerate another. Sea urchins are an important article of food in Europe and the West Indies.

The annelids are worms whose bodies are made up of rings or segments.

\title{
Alcove 9 Annelids
} They are inhabitants of both fresh and salt water, many kinds living in the mud and sand of the shore while others bore into wood and shells. The "houses" that these annelids build are often very beautiful and interesting. The common earthworm is perhaps the most familiar of this group. In the window is a group showing a section of a mud flat on the New England coast with the variety of worm life found in what to the casual observer seems to be an uninhabited area.

Arthropods include the familiar crabs, lobsters, insects and their relatives.

\section{Alcove 10 Arthropods} The number of existing species in this group is greater than that of all the rest of the animal and vegetable kingdoms together. No other group comprises so many species useful or harmful to man. In the case in the center of the alcove is a model Crustaceans showing the anatomy of the common lobster, also enlarged and

Insects models showing heads of various species of insects. On the wall are two of the largest specimens of lobsters that have ever been taken. They weighed when alive thirty-one and thirty-four pounds respectively. The largest of the arthropods is the giant crab of Japan a specimen of which is placed on the wall.

This group is second only to the arthropods in the vast number and 
diversity of forms which it embraces, including marine, fresh water and

Alcove 11

Mollusks

Model of Clam and Oyster land animals. 111 mollusks have soft boxlies, but nearly all of them secrete a shell which in many species is of pearly material (mother-of-pearl). Well-known examples of this group are the common clam and oyster and enlarged models in the center case show the anatomy of these species. The largest species is the huge "bear's paw" or furbelowed dem of the eastern seas.

Vertebrates include the largest, most powerful and most intelligent of animals. The group culminates in man who still bears

Alcove 12 witness to his chordate ancestry in the retention of a chorda Vertebrates and gill clefts during embryonic life. The models in the central case show the development of the egg of typical vertebrates.

An exceptionally large specimen of beautiful madrepore coral is in the case near the entrance, and the associations of marine life that may be found Coral among the coral reefs of the Bahamas are represented by several smaller groups in the center of the hall. Certain of the groups in this section of the hall illustrate various biological principles associated with the name of Darwin. The variation in form, size and color of the snail and the variation of the shell of the common scallop are graphically shown.

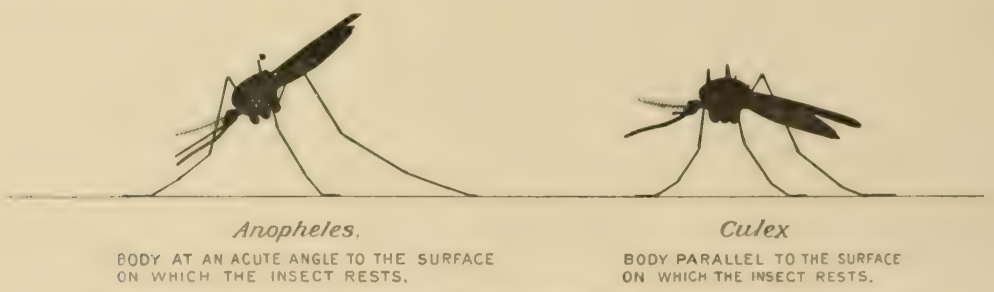

Characteristic resting positions of malarial and common mosquitoes

Four large models in the center of the hall show the mosquito which is the cause of the spread of malaria. These models represent Models of the insect enlarged seventy-five diameters or in volume four the Malarial hundrerl thousand times the natural size. The mosquite in Mosquito its development undergoes a metamorphosis. The model at the left shows the aquatic larval stage; the larve are the "wrigglers" of our rain water barrels. The next model is the pupal stage, also aquatic. The third model is of the adult male mosquito which is harmless since it never bites man. The fourth model shows the adult female mosquito in the attitude of biting. In another case is a series of models showing the life cycle of the malarial germ in the blood of man and in the mosquito.

[Return to the elecators.] 


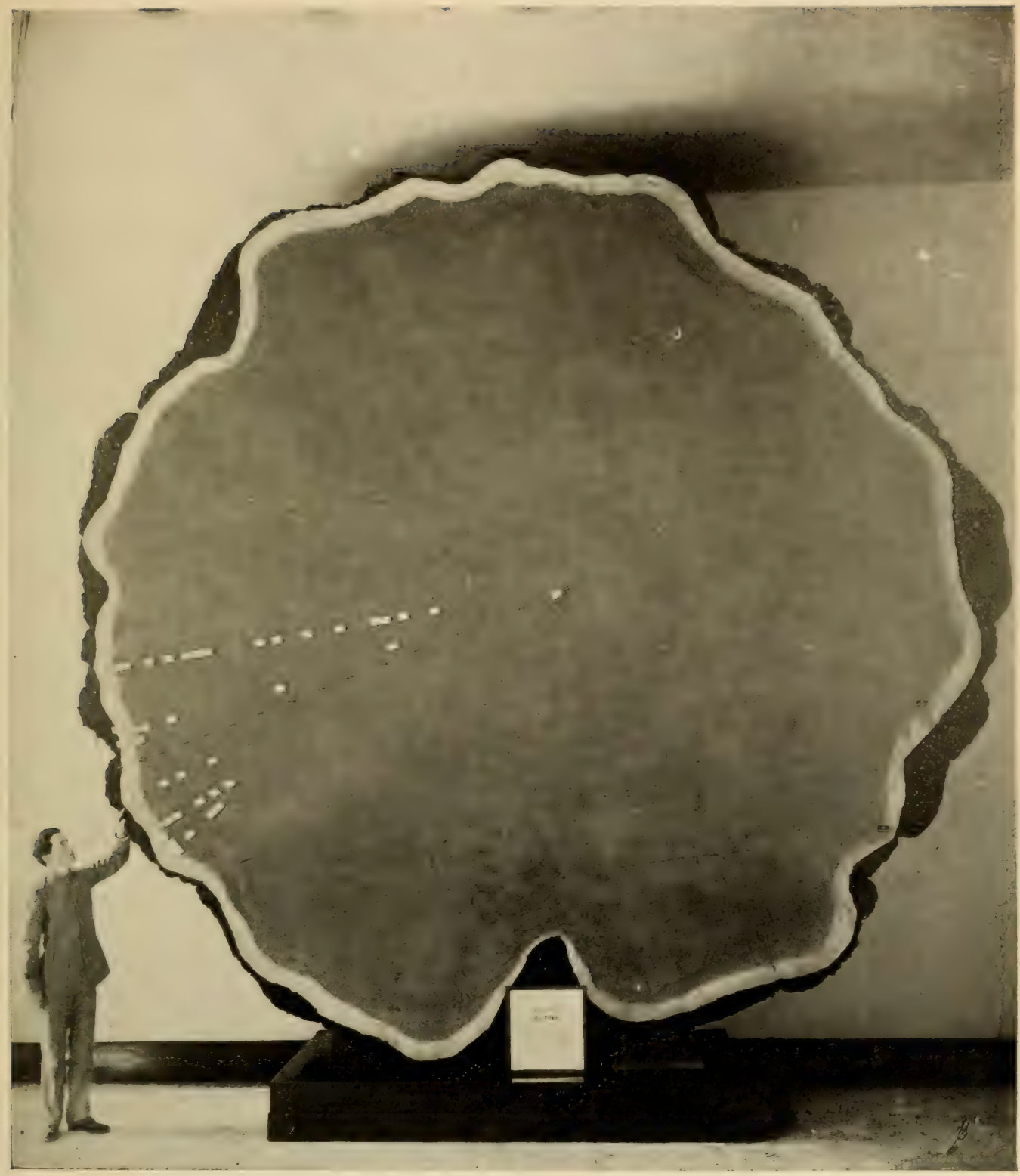

the "Big tree" of california

On the west wall of Darwin Hall are sections of the coast redwood and Big Tree of California. The tags on the latter indicate historical events that occurred during the life of the tree. [See Guide Leaflet No. 8]

This individual Big Tree which was 300 feet high grew for 1341 years, from 550 to 1891 , when it was cut and brought to the Museum. It was nearly a thousand years old when Columbus came to America and more than a thousand when Harvey discovered the circulation of the blood

This largest, oldest, most majestic tree in the world exists only in ten small forests - groves they should almost be called - on the western slope of the Sierras. The trees are in large part under government control, so may continue to live through several generations of men 


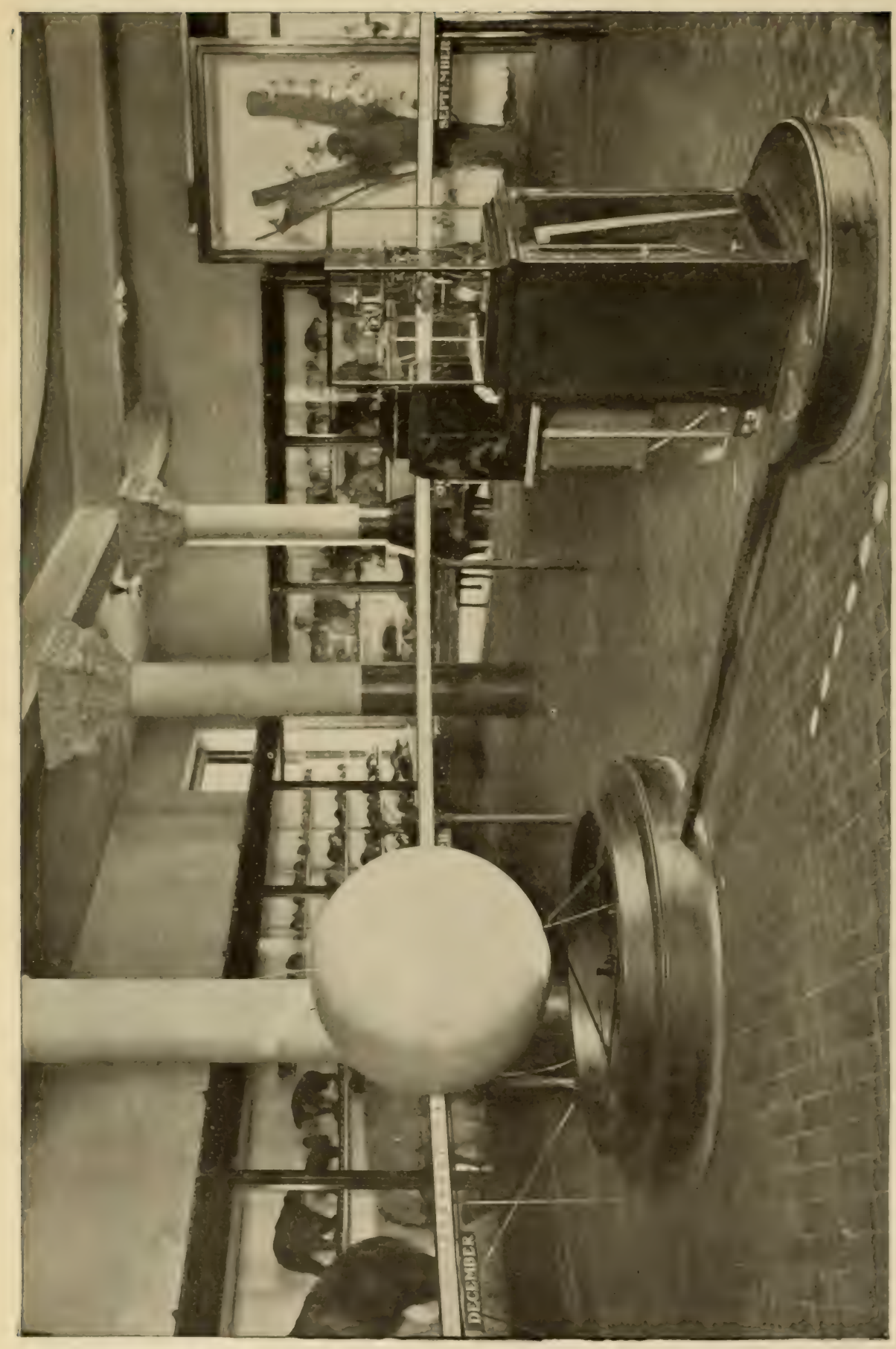

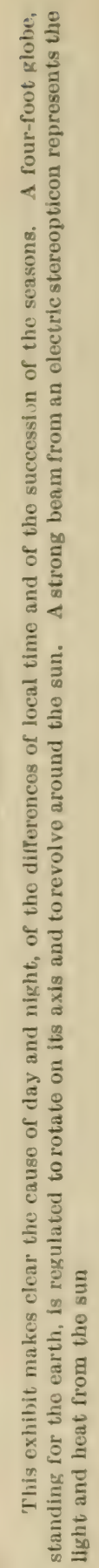




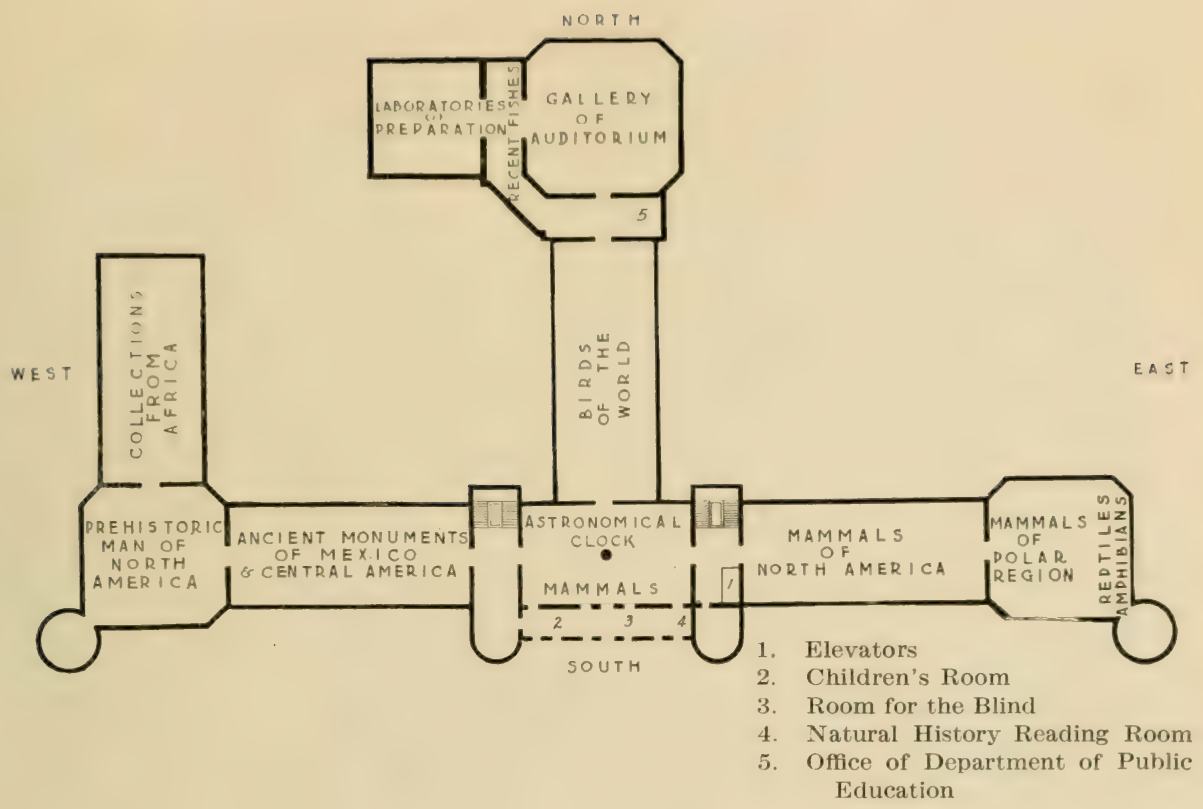

SECOND FLOOR

SOUTH PAVILION

Mammals

Passing to the left from the elevator we enter the South Pavilion includAstronomi- ing the Mammals, and also in the center an astronomical cal Clock clock. This is a model illustrating the movements of the earth and designed to tell the time of day. Full explanation is found on the label.

The various breeds of domesticated dogs are shown in the case on the east wall. This collection illustrates the variations which a species may

Dogs undergo in domestication. The dog has been the companion of man from the very earliest time, but he is believed to have been derived from several wild species. [His remains are found in the shell heaps of primitive man.] The case contains such divergent types as the tiny toy spaniel, which can easily lie in one's hand, and the powerful St. Bernard which has rescued many travelers in the Alps; the hairless dog of Mexico and the shaggy collie useful in tending sheep.

From this case passing to the right around the hall, we find the small carnivores including the weasels, ferrets, ermine, and the foxes and bears. The next case contains the members of the cat family - the lions, tigers, 
leopards and wild cats. The specimen of the Barbary lion was presented Barbary Lion alive to the New York Zoölogical Society by the daughter of "Barbary Lion Mr. Indrew (armegie, and after its death was sent to the Museum. It is a good example of what can be done in mounting an animal by modern methods of taxidermy.

In the cases on the north wall are mounted specimens of the American bison with skeletons near for comparison. The Asiatic elephant is the

\section{Elephant} "Tip" famous "Tip" which was brought to this country in 1881, and for seven years was one of the attractions of Forepaugh's circus. He was given to the City of New York by Mr. Forepaugh and lived in the Central Park Menagerie until 1894, when because of his treacherous disposition it was found necessary to kill him. He is said to have caused the death of several of his keepers, and was twentythree years old when killed.

In a corridor to the left of the astronomical clock as we approach from the elevator are the Natural History Reading Room, the Children's Room and the Room for the Blind.

In the Natural History Reading Room are placed popular books on natural history and especially books deseriptive of the colNatural His- lections in the exhibition halls. The visitor is invited to tory Reading make use of these books. The main library consisting of more than 70,000 volumes on natural science, is on the fifth floor, open free to the public from 9 A. M. to 5 P. M. daily, except Sundays and holidays.

\section{Children's} Room

The Children's Room is designed to arouse interest in natural history and outdoor life. The room is open regularly on Wednesday and Saturday.

The Room for the Blind contains specimens of animals and of

\section{Room for} the Blind Indian implements which can easily be handled and thereYork point. fore are suitable for examination by the blind. The labels are printed in raised type in both Braille and New 


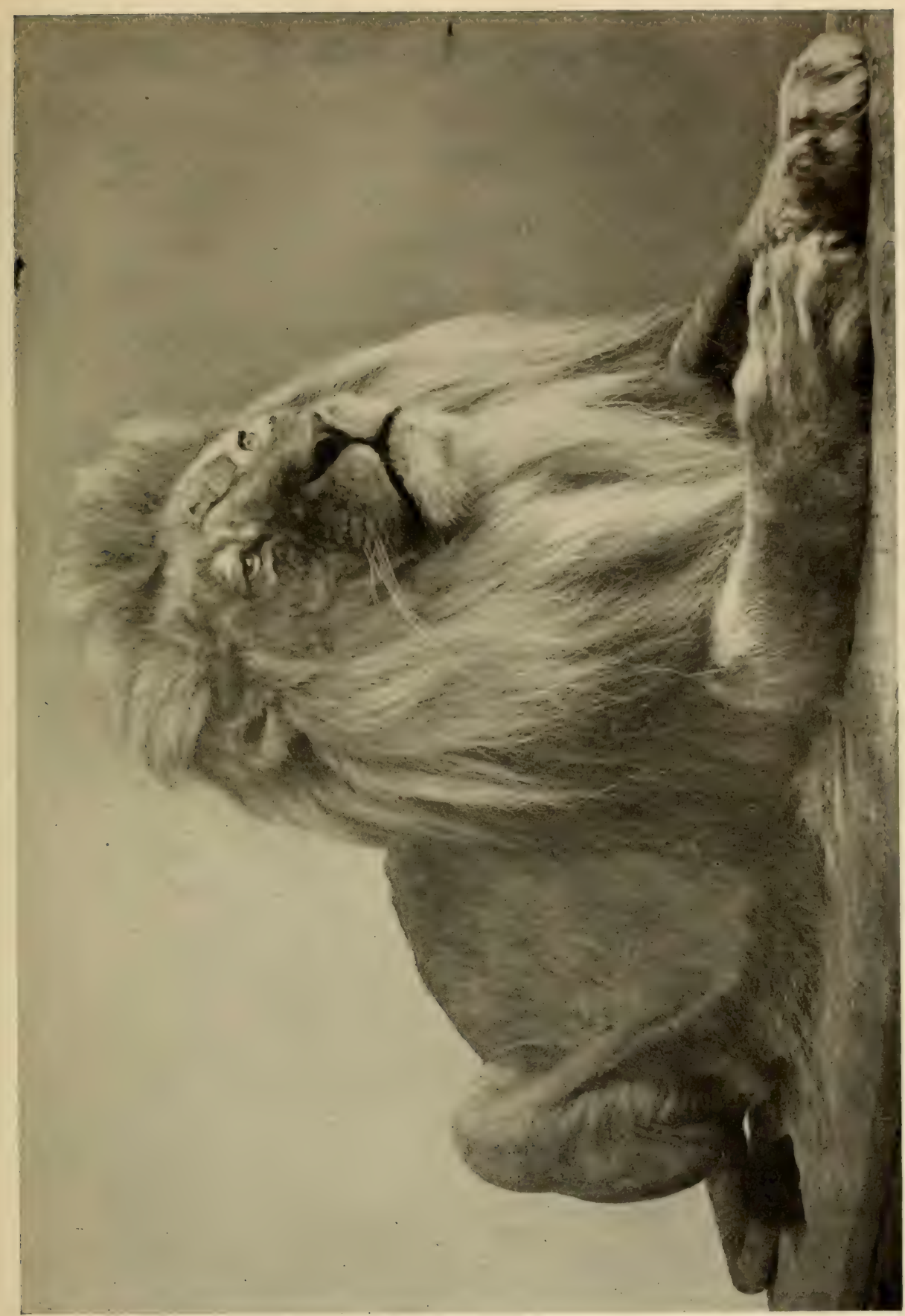




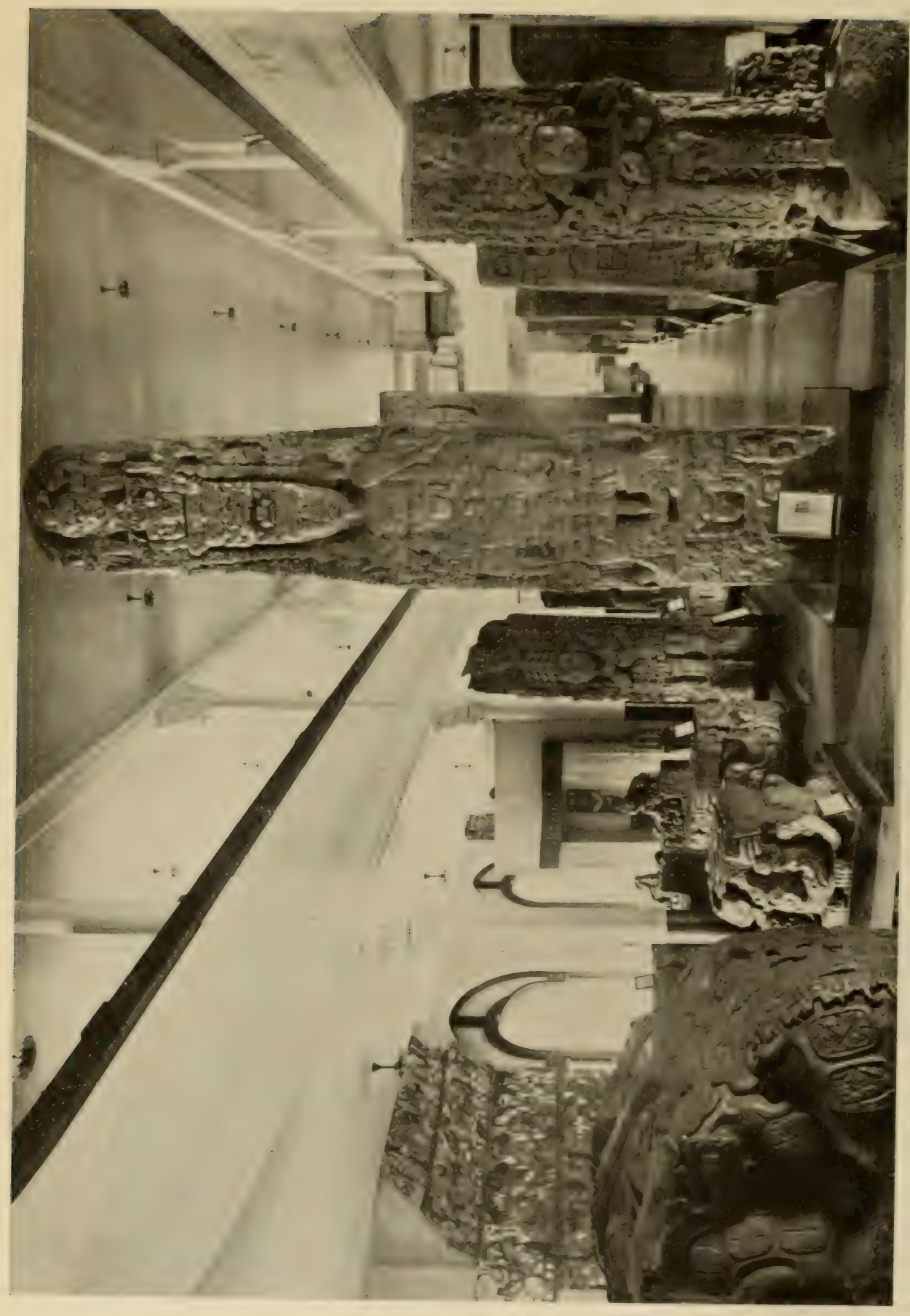

ב

플

छ

¿ है

:

呟

区

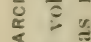

z

क

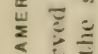

व

点

U⿺辶

文跣

z

赔

ए

등

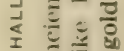

ह

$\bar{\Xi}$

.

달

$-\frac{t}{0}$

츨

을

焉

音

气

플

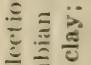

言

$-\frac{1}{5}$

党 


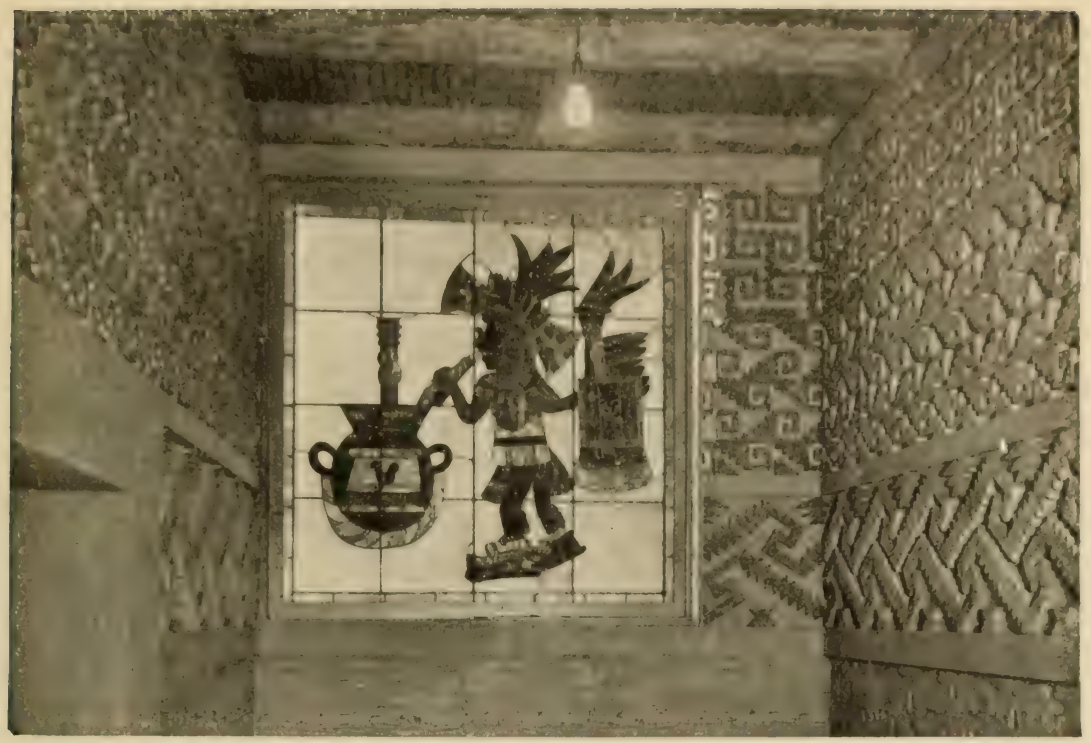

\section{SOUTHWEST WING}

\section{Ancient Monuments of Mexico and Central America}

Continuing west from the South Pavilion containing the astronomical clock, we pass through the West Corridor which is reserved for the exhibits of the Department of Anatomy and Physiology and the Department of Public Health and enter the Southucst Wing devoted chiefly to ancient monuments from Mexico and Central America.

From the entrance to the middle of the hall are collections from South America and Yucatan. The rear of the hall contains material from Mexico. The reproductions illustrate chiefly the sculpture of Mayan and Nahuatl cultures and are the gift of the Duke of Loubat. The material of the Mayan culture comprises plaster casts of the ancient stone monuments, or stelæ and altar stones, the stone and obsidian tools used to carve them, stone sculptures found in excavations and ruined buildings of the ancient city of Copan, and pottery of various designs. At the left of the entrance are two cases of pottery, jade and stone work from Costa Rica and Panama, evidently marking a lower type of civilization.

The casts of the large stone pillars are taken from the ancient stelæ, and which probably were erected as monuments and some of which are Stelæ standing even to-day. Returning to the center of the hall and going back to the east entrance, we see reproductions of stelæ from Copan arranged in order from the oldest and crudest form to a 
higher and finer type of carving, covering a space of time of two or three hundred years. This arrangement applies only to the row of casts on either side, not to the two large central models, nor to the side exhibits. The early stela of about $100 \mathrm{~A}$. I). have hieroglyphs carved in very low relief and with sharp corners, while the hieroglyphs of the later period are cut deeper and in more rounded relief. In the earlier stela human figures are carved in a crude blocklike manner, with protruding eyes and angular limbs. Students of this subject have been able to decipher a large part of these hieroglyphs and figures which give dates and reckonings.

The monolithic monuments mark the first period of Mayan culture. Altar Stone The large altar stone to the left of the entrance is also of the first period and is perhaps the finest and most perfectly preserved specimen of which we have a reproduction. It represents a double-headed monster which had religious significance.

The second period of Mayan culture was more architectural in style and the art was a higher type, as is evidenced by the profile work in the reproductions of the carvings from the temples at Palenque shown on the north side of the hall. On the south wall another example of the art of this period is the copy of the painted sculpture from the "Temple of the Jaguars" at Chichen-Itza, Yucatan. It shows warriors in procession going to worship some god and their prayers are represented as coming from their lips. This sculpture shows strong evidence of Mexican influence in certain of its details.

Next in order is the Nahuatl culture, which is represented in the alcove rases by ancient pottery, musical instruments, copper objects, and ornaments made of obsidian and jade. The Nahua language was spoken by many of the tribes of Mexico and of these the Aztecs inhabited only the City of Mexico. One case contains facsimile reproductions of ancient Codices books called codices which were made of deerskin, paper or cloth. These were historical, religious or civil records and the Spanish burned hundreds of them in their efforts to destroy the native religion. The so-called sacrificial stone or the "Stone of Tizoc" has carved Calendar around it records of Aztec conquests of various cities. The Stone "Calendar Stone" on the south wall, was found in the City of Mexico and the original is now in the museum of that city.

Other culture areas in Mexico are shown by the names Tarascan, Zapotecan, etc. The Tarascan is situated mostly in the states of Michoacan Funeral Urns and Jalisco. The most interesting objects from this area are funeral urns which represent men and women in their everyday dress. The modeling is very peculiar. The Zapotecan culture area is situated in Southern Mexico and the most famous ruins are 
Mitla and Monte Alban. A cruciform tomb at Guiaroo, near the ruins of Mitla, is shown by a model at this end of the room. The collection of goldwork in an adjoining case is very fine.

\section{SOUTHWEST PAVILION}

\section{Prehistoric Man of North America}

Continuing west we pass into the Southuest Pacilion likewise given over to archeology, in this instance that of North America. Here are examples of ancient pottery, arrow-heads, stone axes and other implements of stone and bone, mostly from burial mounds. Notice that the arrangement from left to right around the hall is by states. Read the label at the entrance of this hall. For more complete description read case labels and various books of information on the exhibits in this room. [See Guide Leaflet No. 2].

\section{WEST WING}

\section{Collections from Africa}

Opening to the north from this hall of North American Archæology is the hall devoted chiefly to African ethnology although temporarily African mammals also are installed here. The installation is geographical, i. e., as the visitor proceeds through the hall from south to north he meets the tribes that would be found in passing from south to north of Africa, and the west coast is represented along the west wall, the east coast along the east wall.

The hippopotamus is the famous "Caliph," who lived for twenty years "Caliph" in the Central Park Zoo and died when he was forty years old. He was the largest hippopotamus ever recorded.

The central portion of the hall is given over to the anthropology of the

\section{Congo}

Collections Congo, the collections being largely the gift of Leopold II of Belgium. The decorative frieze is designed to give an idea of the character of the country and again the arrangement of the panels is geographical. The window transparencies show scenes of the daily life of the people, the thatched houses in which they live, the games they play and the clothes they wear. The South African negro is essentially an agriculturist; both men and women plant and hoe. Maize, millet, rice, beans, sweet potatoes and pumpkins are among the products.

Hunting is no longer common, although among some of the tribes they set traps for leopards and lions and hunt the hippopotamus. In one tribe 
fishing is accomplished by putting poison into the water to stupify the fish which are then gathered in the hands by hundreds.

These primitive people of the Congo display remarkable skill in working iron, as an examination of their weapons of war and of the chase will show. Wood-carving, weaving, and spinning are done by the men; pottery is made by the women. Musical instruments are numerous. An exhibition of bronze and brass castings, a craft among the Benin and unheard of before 1897 , is in the north end of the hall. Many of these bronzes portray cultural traits. This method of casting was employed in Europe in the Renaissance period. How old the art may be and how much of it is really native is a question.

Bark cloth, shown in some of the cases, is used for bed mats and clothing. In the case at the south end of the Congo collections are a number of so-

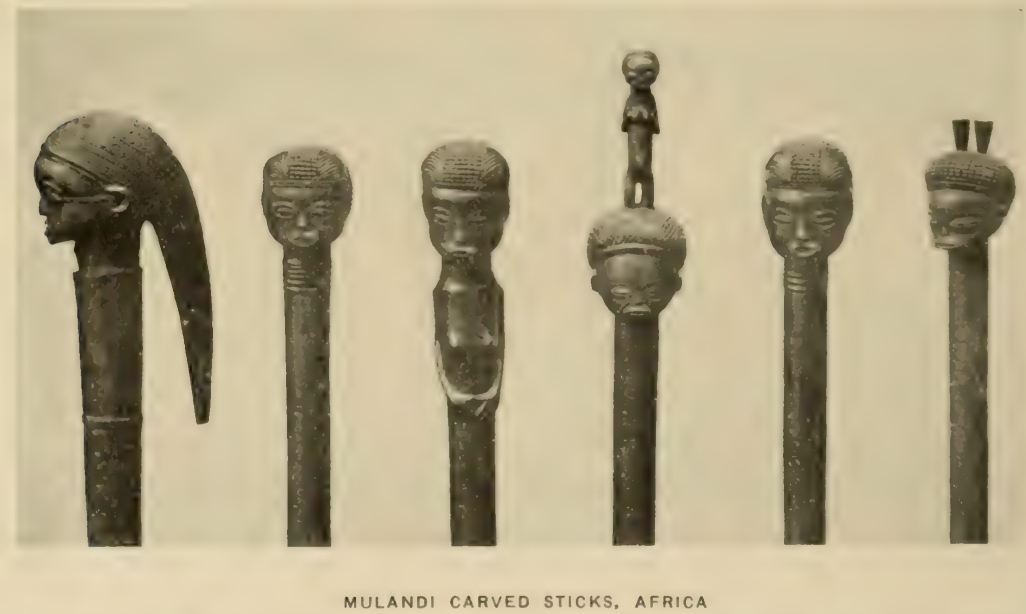

Wood carving is a highly developed art in South-central Africa and the Congo.

The carving on these knob-sticks represents great power of finish and execution

called "pile blankets" which the men weave and the women decorate.

The countless number of knives, spears and warlike implements is suggestive of the manner in which these people live; they are never certain of not being attacked. They make few permanent things and store up little food in time of plenty.

Fetish worship is common. Some of these fetishes are supposed to give security in battle or to ward off ills. The ceremonial masks of which a great number are on exhibition, are owned and worn mostly by the shamans or priests. Ancestor worship is found among some tribes.

[Return to the astronomical clock.] 


\section{SOUTH CENTRAL WING}

\section{BIRDS OF TIIE WORLD}

Going north from the hall of mammals past the case containing the lion "Hannibal," we enter the hall containing the general collection of birds of the world. In the first four cases on the right the 13,000 known species of birds are represented by typical examples of the principal Birds of the groups arranged according to what is believed to be their World natural relationship. The remaining cases on the right wall and all of those on the left show the geographical distribution of the bird fauna of the world. The specimens are grouped according to the great faunal regions - namely, the South American Temperate realm, American Tropical, North American Temperate, African, Indo-Malay and Australian realms. These cases in connection with the accompanying maps give opportunity for a comparative study of the birds of these regions.

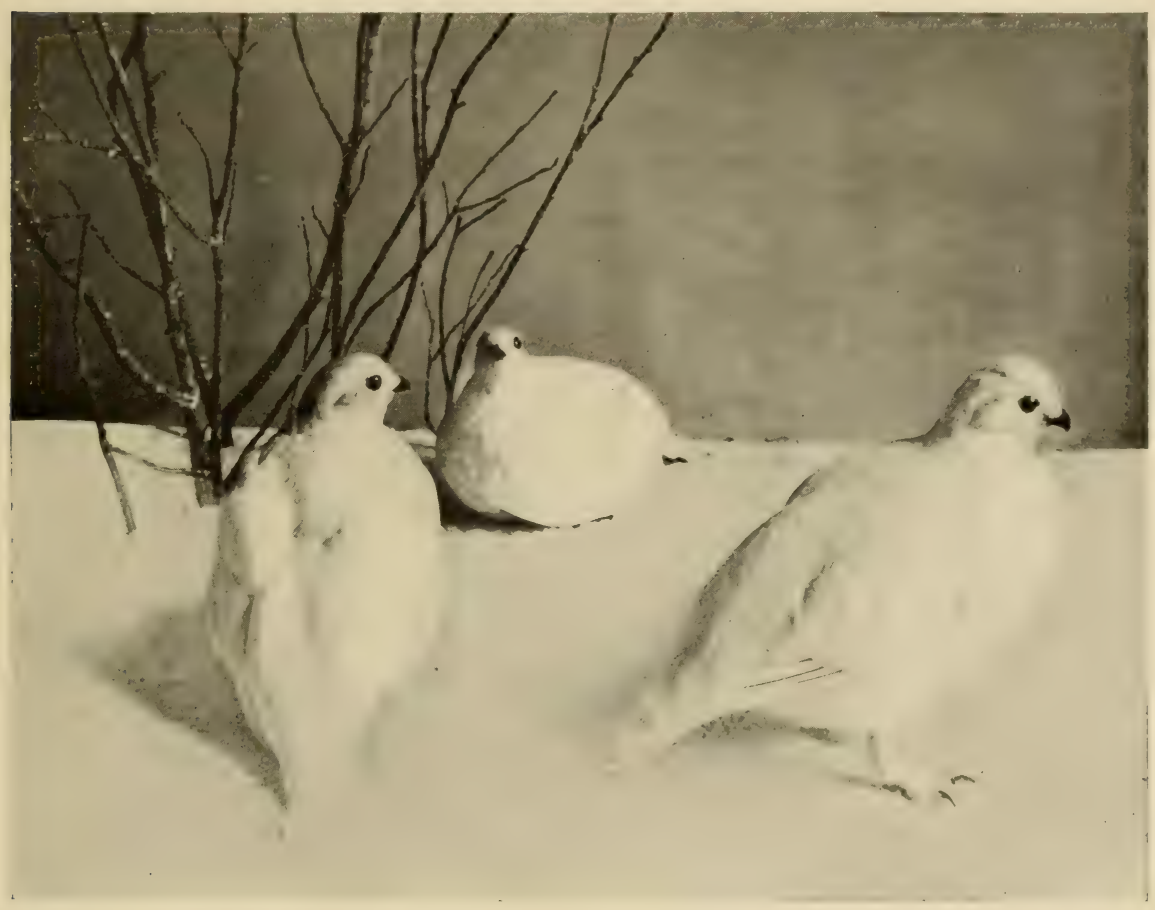

THE PTARMIGAN IN WINTER

One of a series of four small groups showing this bird's seasonal changes of color as brought about by molting and feather growth 
In the middle of the hall are various cases showing characteristic scenes Ptarmigan of bird life. A group of ptarmigan in seasonal plumage is at the entrance. Unlike most birds the ptarmigan has three distinct molts a year: From the pure white of winter it passes in the spring into the dark gray-brown plumage of summer. It again sheds its feathers in the fall, acepuiring a plumage of lighter brown which harmonizes more nearly with its surroundings. Then later it passes into its Great Auk winter plumage of white. Beyond the ptarmigan group is the great auk case and the Labrador duck group; both of

Labrador Duck these birds are now extinct, and there are only four mounted specimens of the former in this country.

In a case near the center of the hall is an exhibit illustrating the differences in structure of the beaks and claws of birds, and some of the habits of various species of North American woodpeckers.

At the north end of the hall is a nearly complete collection of the birds of paradise of the world, presented by Mrs. Frank K. Sturgis. Birds of

Birds of paradise are confined exclusively to New Guinea and a few Paradise adjacent islands. This collection illustrates the remarkable modifications that the feathers of a single group of birds may undergo in nature.

Finback Whale
Suspended from the ceiling of this hall is the skeleton of a finback whale, sixty-two feet in length.

\section{CORRIDOR OF CENTRAL PAVILION}

\section{Recent Fishes}

The doorway at the north end of the hall of the birds of the world leading to the rear of the bird of paradise case opens into the gallery of the Auditorium and to the corridor devoted to the general collection of recent fishes. This hall contains representatives of the marine and fresh-water fishes of the world. The exhibit includes typical examples of the various groups of vertebrates popularly comprised in the term "fishes" and is arranged to show first the most primitive fishes, the sharks, then successively various groups leading up to the teleosts or bony fishes, which were the last to appear in the course of evolution. These groups are as follows: lampreys and hagfishes, eel-like creatures with round sucking mouths and no jaws, hence not really fishes in the strict sense of the word; sharks and rays, the most primitive, that is the most ancient type of fishes; chimeroids or rat-fishes, a group of highly modified sharks living mostly in the deep sea; lungfishes, an ancient group represented at the present time by three kinds or genera, living respectively in the rivers of Australia, 
Afriea and South America; ganoids, including the sturgeon, gar pike, paddlefish, bowfin and the African bichirs. In earlier geological ages ganoids were more numerous than other fishes, but at present they are few and relatively unimportant.

The teleosts or bony fishes comprise about 10,500 species, or nearly nine-tenths of all existing forms, including the majority of food and game fishes, such as the bass, carp, cod, eel and herring.

An exhibit of fossil fishes is to be found on the fourth floor.

[Return to the astronomical clock and the corridor of the elevators.]

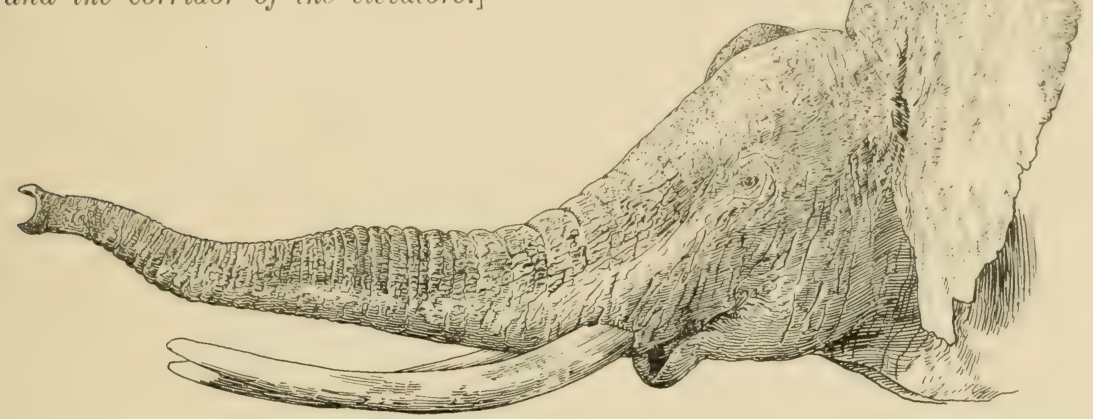

SOUTHEAST WING

\section{Mammals of North America}

Continuing east beyond the elevator corridor, we enter the hall containing specimens of North American mammals. In the cases on the west wall are several groups illustrating the mammals found within fifty miles of New York City. The first of these groups shows the opossum, the sole repreOpossum sentative in the United States of the marsupial or pouched mammal. With what appear to be the head and ears of a pig and the prehensile tail of a monkey, with a strange pouch for the transportation of the young, and with proverbial cunning and remarkable tenacity of life, the opossum is one of the quaintest and most interesting of North American mammals. This is the animal so famous in the negro songs of the South.

Raccoon

Foxes

sly cunning.

Next in order is the raccoon, more commonly known as the "coon." It is nocturnal in habit and makes its nest in hollow trees. Two species of fox are shown, the red fox and the gray fox, both of which are justly famous for their 
The common skunk is a very useful although greatly abused animal. Skunk

While it oceasionally destroys poultry and other birds, its principal food consists of injurious insects and field mice. Its defensive weapon is an excessively fetid fluid secreted by a pair of glands situated near the batse of the tail. It has the ability to e.ject this fluid to a

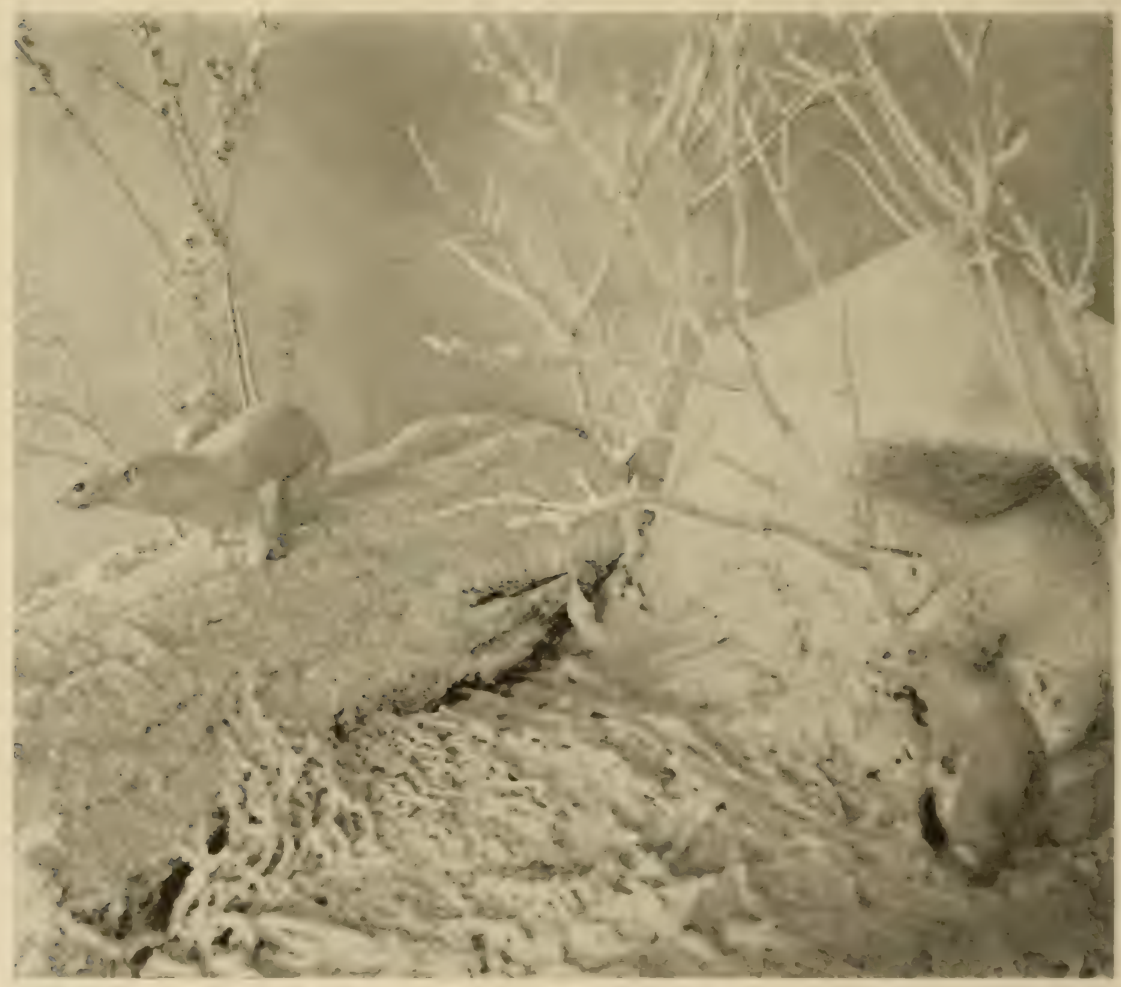

THE WEASEL GROUP

One of the groups representing the small mammals found within fifty miles of New York City. The others of the series show opossum, raccoon, red and gray foxes, skunk, mink, muskrat, woodchuck, rabbits and squirrels. The list includes some "fur-bearing" species; weasel fur is of ten used instead of ermine.

considerable distance. Its skin makes a valuable fur known as "Alaskan sable."

Mink and Weasel

Two other fur-bearing animals shown are the mink and the weasel, the latter in hoth its summer dress of dull brown and its winter coat of white. Weasel fur is often used in place of ermine. 


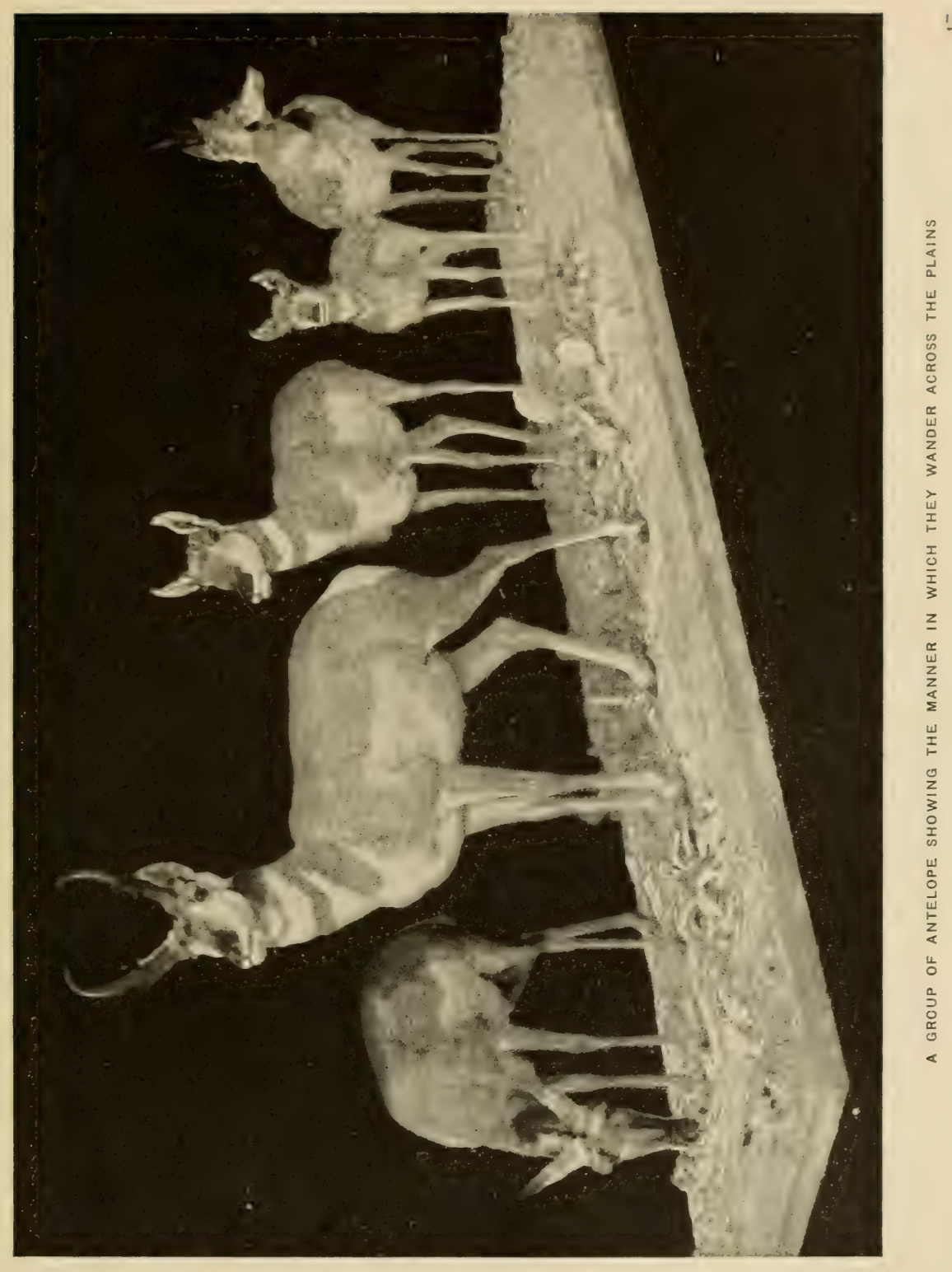




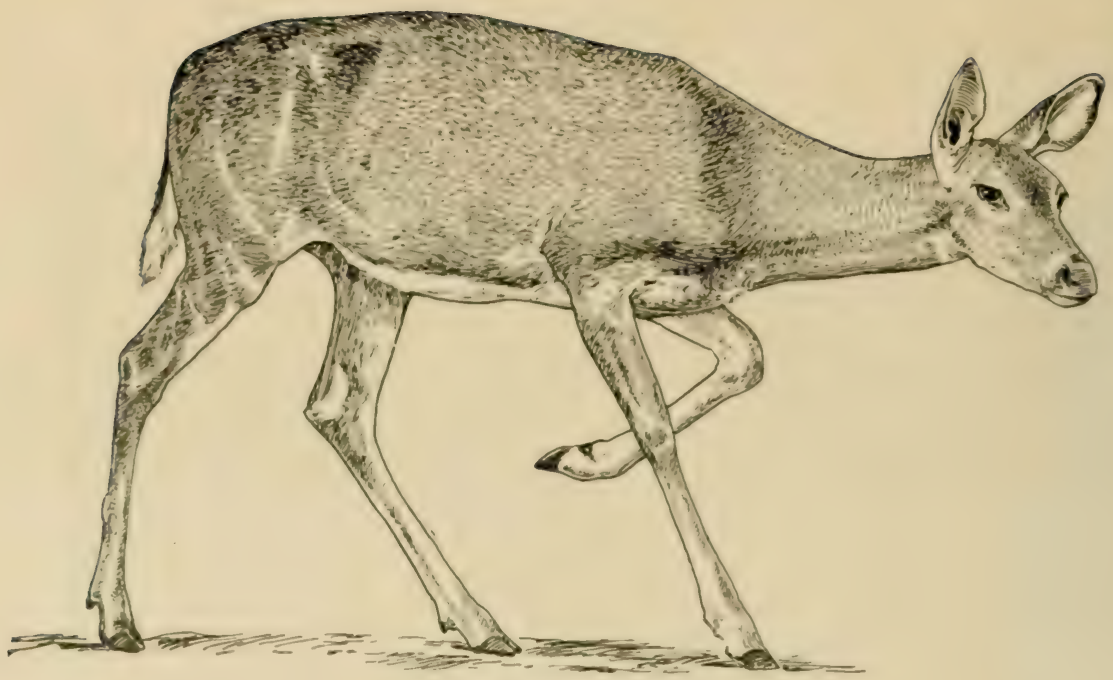

THE VIRGINIA DEER

Line drawing from the mounted specimen. This Viryinia doe stands as the first example in the Museum of the new methods of animal sculpture as opposed to the old taxidermy

Another fur-bearing animal shown is the muskrat. In the group are Muskrat seen its summer home, usually a burrow in the bank of a , stream or pond, and its winter mound, constructed of swamp grass and roots mixed with mud. Muskrats are extensively trapped for their fur.

The woodchuck or ground hog is a vegetable feeder but does very little Woodchuck harm to crops. It hibernates for a large part of the year usually from September to April. The old legend says that the ground hog comes out of his hole on the second of February and if it

Hares and bright and he sees his shadow, he goes back into his hole for Squirrels six weeks longer and we may expect more cold weather. Other groups represent the varying hare and the common species of squirrels.

In the central section of the hall is a group of moose. It represents an early autumn scene in a secondgrowth forest in New Brunswick, and illusMoose trates one of the favorite feeding grounds of the moose. Group Beyond the moose exhibit are species of mammals found within fifty miles of New York City, namely Virginia deer, the otter and the wild cat or lynx. The buffalo group gives a typical bit of the prairie traversed by buffalo trails, while the members of the herd Bison Group represent different stages of growth of the buffalo. This is the animal which formerly roamed in countless numbers over the western plains but which is now reduced to a few insignificant herds. 48 
On the south side of the hall are displayed the cloven-hoofed animals Antelope Group of North America. These include sheep, musk ox, caribou, collared peccary and various species of deer. At the extreme end of the hall is a group of antelope showing the manner in which they wander across the plains. This animal possesses the power to raise or lower at will the long hairs on the rump in such a manner that the light is reflected as from a mirror, and by this flashing the animal is said to signal approaching danger. On the north side of the hall are shown the rodents and carnivores. [See Guide Leaflet No. 5.]

\section{SOUTHEAST PAVILION}

\section{Mammals of the Polar Region}

\section{Reptiles and Amphibians}

Proceeding eastward beyond the antelope group we enter the Southeast Pavilion containing the boreal

Fur Seal Group animals of North America and at the extreme east of the hall the exhibit of reptiles and amphibians. At the entrance is shown a family of fur seals as it appears in one of the seal rookeries in the Pribilof Islands. During the breeding: season the fur seals, from which is obtained the sealskin of commerce, congregate in their island rookeries in great numbers and have been so hunted by man that they are threatened with extinction.

Grant's Grant's caribou inhabit the barren ground of the extreme Caribou western end of the Alaskan peninsula. The type specimen of Group this species is in the Museum.

The mountain sheep inhabit the more inaccessible mountain regions

\section{Mountain} Sheep Group of the West from the northern part of Mexico to the shores of the Arctic ocean. It is probable that they originated in the mountains of Central Asia and spread through Siberia into the American continent. The geographic variation of the mountain sheep of North America is shown on the section of a globe near the group. [See Guide Leaflet No. 5.] 


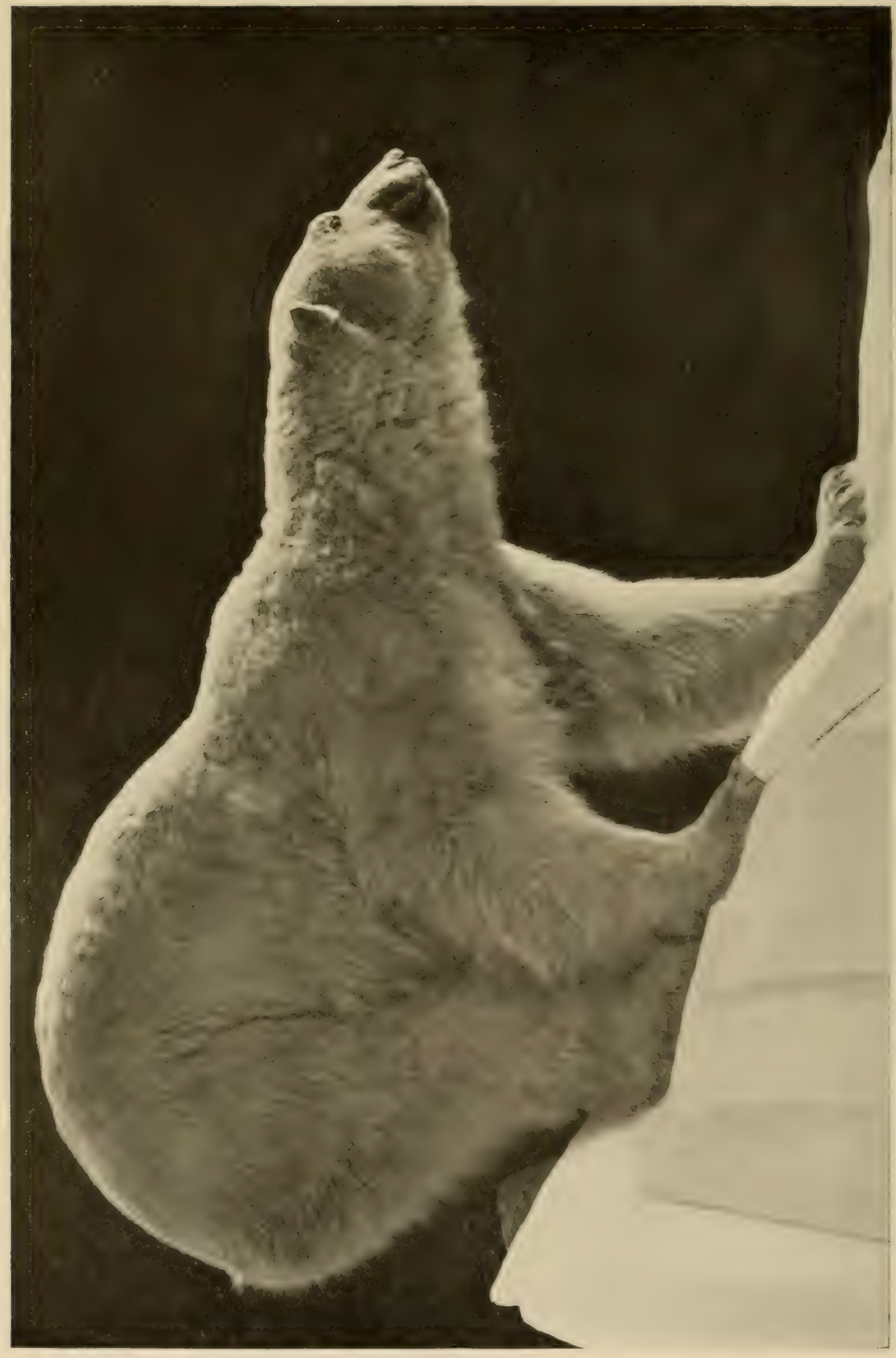

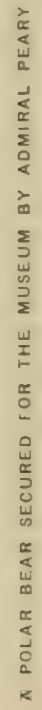


At the right is a large wall case group of the Atlantic walrus. These Walrus huge mammals are relatives of the seals, inhabit the waters Group of the far north and are still fairly abundant along the shores of Greenland. The seal and walrus are the animals which play such an important part in the life of the Eskimo. From these animals come the principal food supply, skins for clothing, for fishing and hunting gear, boat covers, and harnesses for dog teams; from bones and tusks are made knives. Polar Bear bows, harpoons, and other hunting and cooking utensils. The polar bear and cubs were secured for the Museum by Admiral Peary.

The Roosevelt elk or wapiti inhabits the Coast Range of mountains from Roosevelt Elk British Columbia to northern California. These animals are although formerly very abundant.

The specimens in the musk ox group were collected for the Museum Peary by Admiral Peary in 1896. Musk oxen inhabit the snowMusk ox covered wastes of the Arctic barrens, living upon willow Group leaves, lichen and bark dug up from under the snow.

The collection of reptiles and amphibians is exhibited at the east side Reptiles and of this hall and in the adjoining tower room. Because of Amphibians the difficulty of preserving the natural covering of many of these animals they are usually exhibited in jars of alcohol. In the specimens on exhibition here the perishable parts have been cast in wax from life; for example in the star tortoise the original "shells" of the specimens are used, while the head, neck and legs are restored in wax.

The classification of these animals is shown in the tall cases along the west side of the alcove, the case to the right of the entrance being devoted to the amphibians; the others to lizards, snakes, turtles and crocodiles. The mounting not only brings out the principal features of the species exhibited, but in many instances illustrates also some distinctive habit of the animals; for instance the common newt, one of the salamanders, is represented by a series of five life-size casts showing the process of shedding the skin; Pickering's hyla or the "spring peeper" is shown with vocal sacs inflated; the poisonous bushmaster is represented with its eggs, and so on.

The groups in the center of the hall represent various reptiles as they appear in their natural haunts. They include the tuberculated iguana, the water moccasin, the diamond-backed rattlesnake, the Texas rattlesnake, the copperhead, the Gila monster, the pine snake, the box tortoise and the common painted turtle.

One of the most interesting of the groups is a jungle scene in India show- 


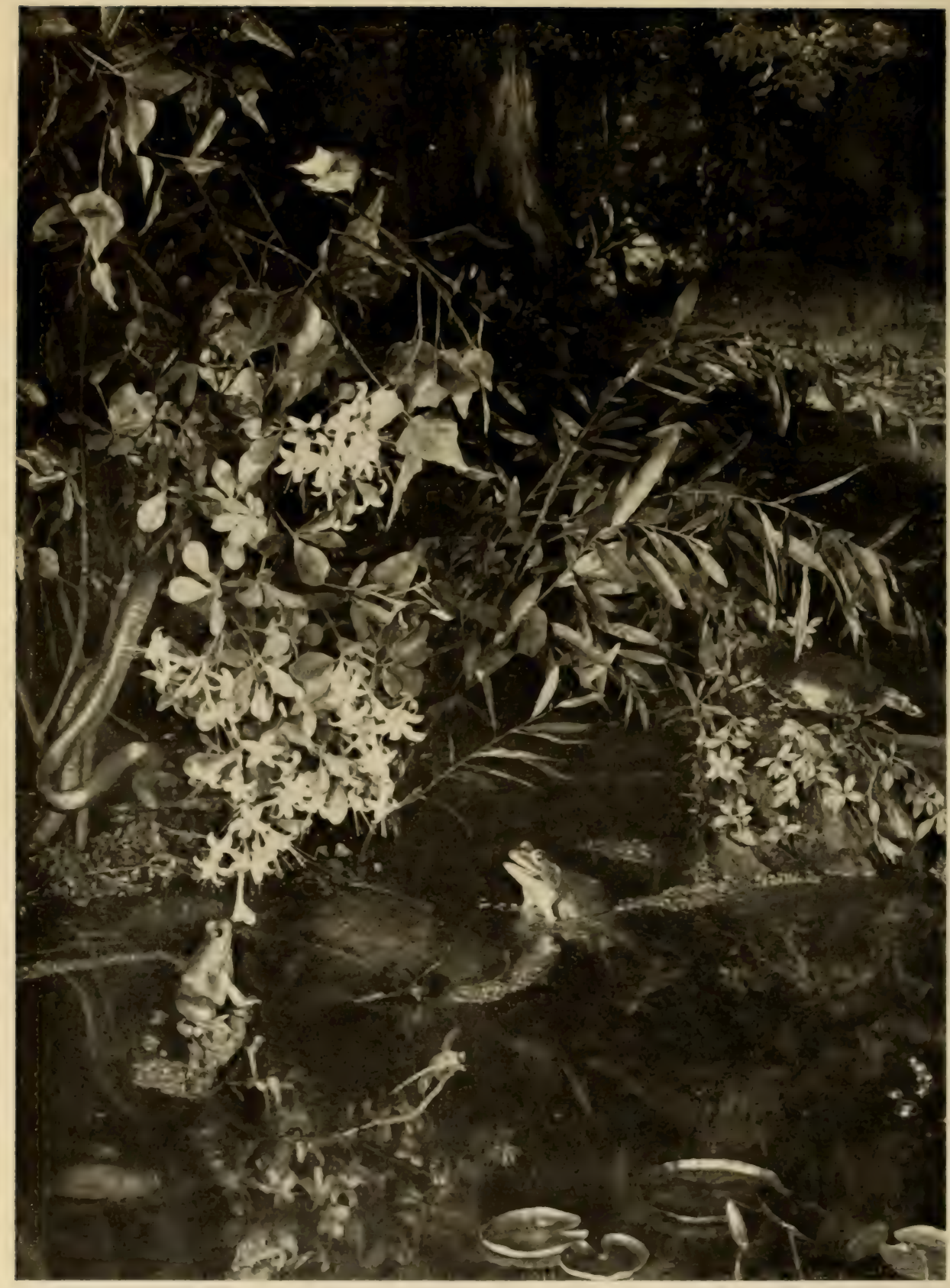

A PORTION OF THE BULLFROG GROUP

Two frogs are engrossed in a chickadee on the birch branch above. The smaller frog seems likely to fall a prey to a black snake ready to strike from the white azalea near

The scene is typical of southern New England in July. The frogs and the reptiles are wax casts from life. The various activities of bullfrog life are set forth. with the relations to birds and small mammals. fish. snakes. turtles, insects and snails. The metamorphosis from the tadpole is also shown 52 
ing a water monitor, which is the largest of living lizards, the poisonous Cobra Group Russell's viper and the deadly spectacled cobra, the last with hood distended and poised ready to strike. The cobra is said to be the cause of a great majority of the 20,000 deaths which annually occur in India from snake bite. Examine carefully the group of the copperCopperhead head snake or "red-eye," one of the two species of poisonous Snake Group snakes to be found in the vicinity of New York and also the group contrasting the harmless water snake with the poisonous water moceasin of southern cypress swamps. Two groups are devoted to rattlesnakes, which are easily recognized by the string of rattles at the end of the tail, by means of which they give warning before they strike. There are comparatively few species of poisonous snakes in the United States, about sixteen in all, comprising rattlesnakes, the moccasin, copperhead and two kinds of coral snake. All other species are harmless and in spite of the almost universal prejudice against them are a very useful ally of man since they live chiefly on rats, mice and insects injurious to crops.

Entering the darkened $\begin{array}{ll}\text { Bullfrog } & \text { tower room we } \\ \text { Group } & \text { find a group of } \\ & \text { unusual inter- }\end{array}$ est, showing the common bullfrog of North America.

This group is a study of the

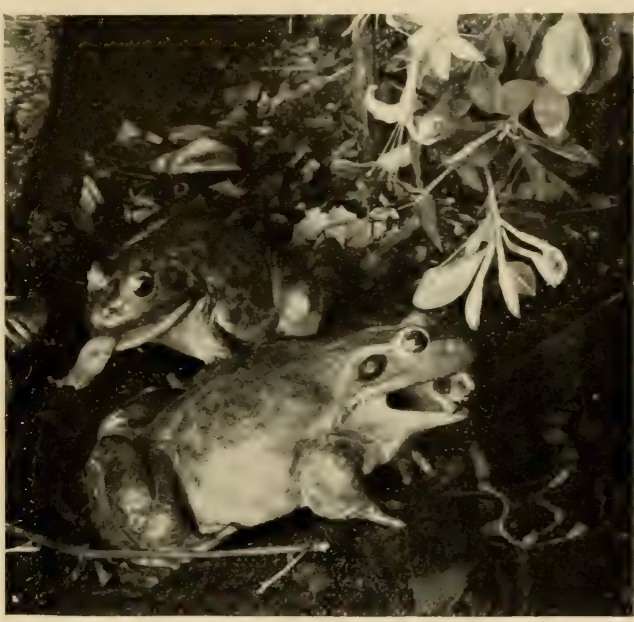

The bullfrog's tongue is fastened in front and the free hinder end can be thrown far out of the mouth to capture insects bullfrog undisturbed in its typical haunt. It illustrates the changes from the tadpole to the"adult frog and shows many of the activities of the frog - its molting, swimming, breathing under water and in air, croaking, and "lying low" before an enemy; also its food habits in relation to small mammals, to birds, snakes, insects, snails, to small fish and turtles.

[Return to the elevators.] 


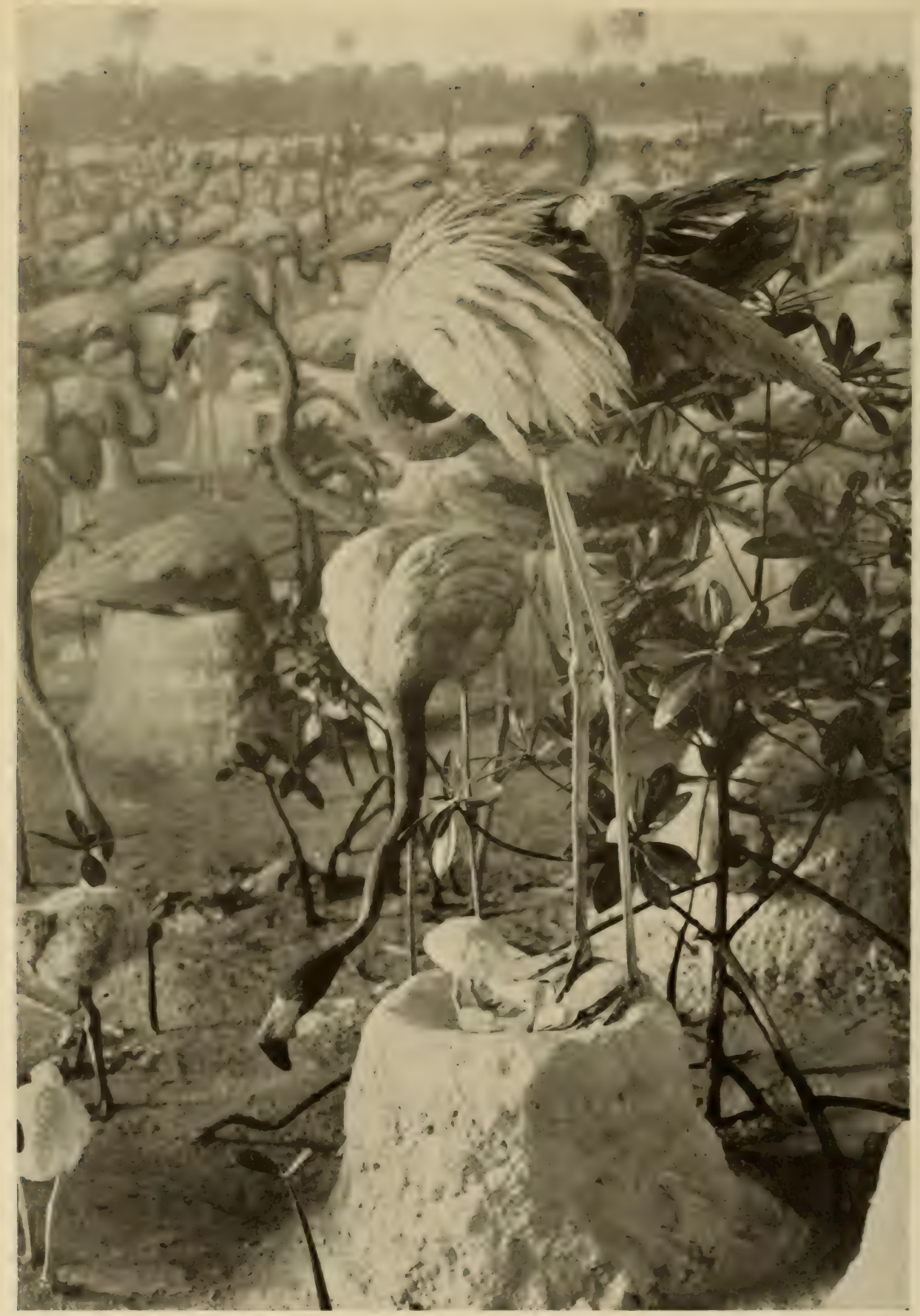

A DETAIL OF THE FLAMINGO GROUP

Neither "protective coloration" nor "cover" ean be said to help in the preservation of this species, for the flaming creatures live on bare islands in colonies thousands strong. Their protection lies in their isolation, their shyness and the open character of the haunt which allows them to see long distances 


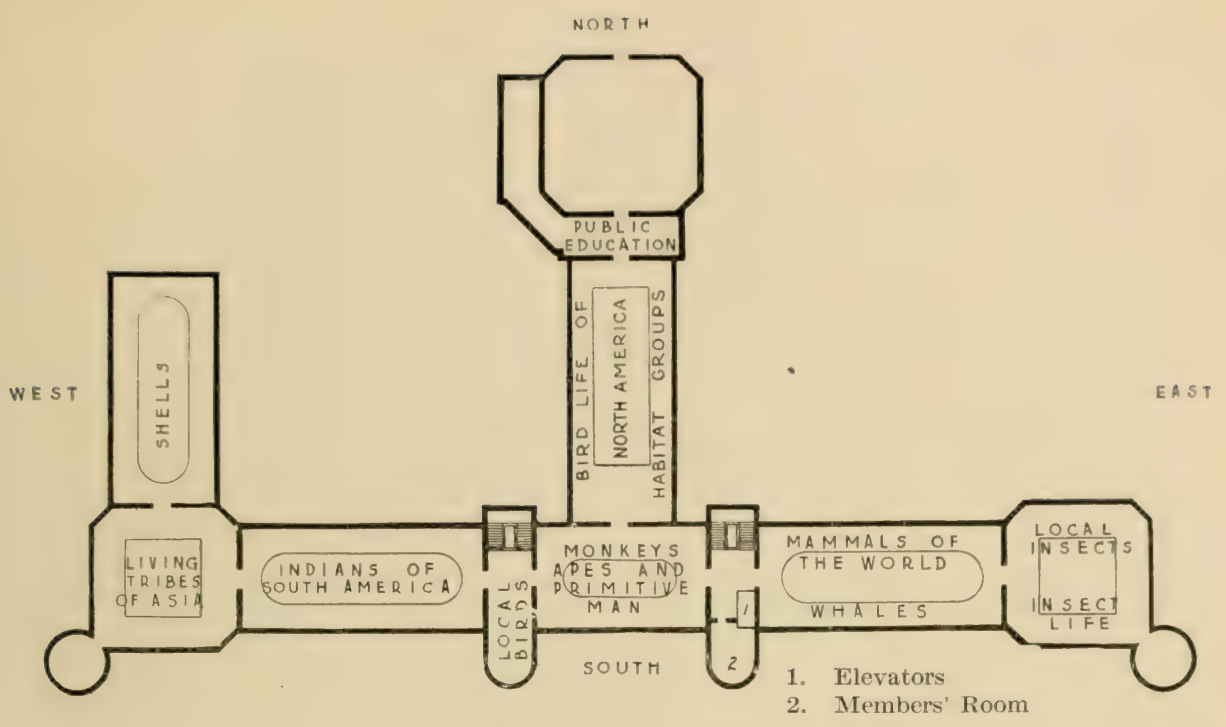

\section{THIRD FLOOR}

\section{SOUTH PAVILION}

1. Monkeys, Apes and Primitive Man

\section{Rodents}

The primates, the monkeys and apes of the world, occupy the South Pacilion of the third floor, the first hall at the left as one Monkeys and Apes turns from the elevators. These animals in structure and brain capacity resemble man more closely than do any other of the mammals, but while man and the apes have sprung from a common ancestor, in no sense has man descended from the existing apes. Orang-utan A family of orang-utans, the most powerful and most ferocious Group of the apes, is shown in a case on the south side of the hall. In another case the skeleton of a chimpanzee, "Mr. Crowley," and of a gorilla are placed beside a skeleton of a man to allow a study of the similarities in structure.

On the other side of the hall will be found the bats, the only mammals Rodents that really fly, and the hares and other rodents, among which the rat, mice and squirrels are familiar examples. The rodents are the most numerous and the most widely distributed of the mammals.

Suspended from the ceiling in the center of the hall is a skeleton of a North Atlantic right whale which is more than forty feet in length. The 


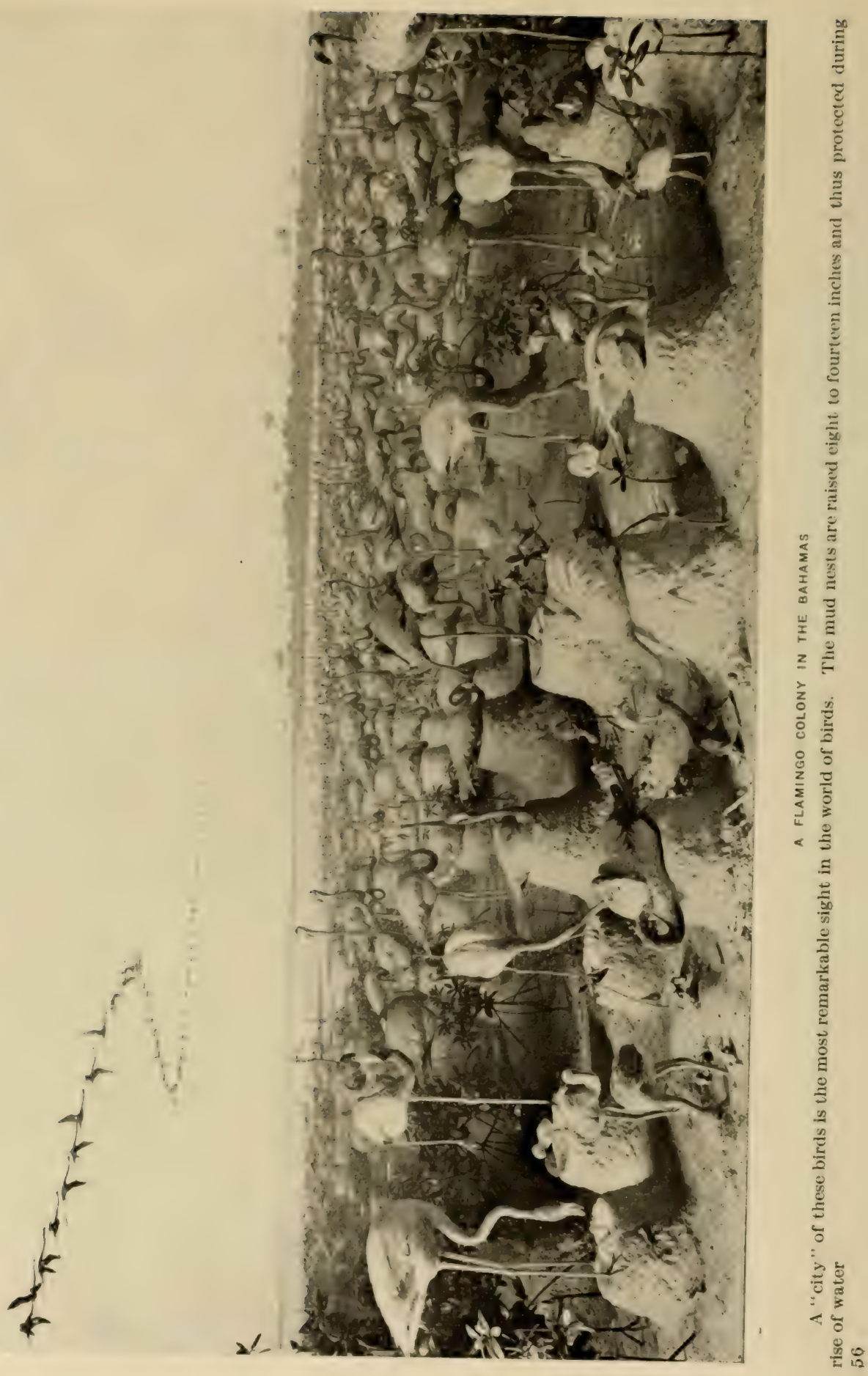




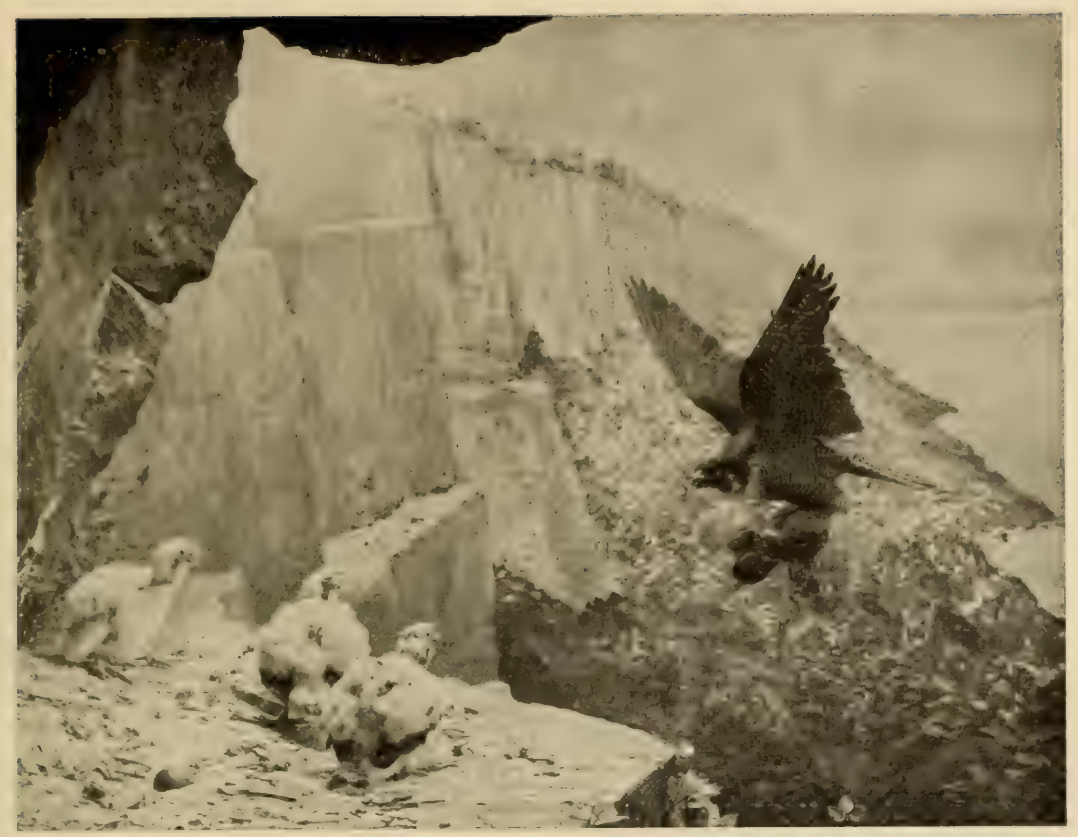

DUCK HAWK ON PALISADES OF THE HUDSON

Realism and artistic effect have been achieved in the "Habitat Bird Groups," and they present vividly many stories of adaptation to environment

hall also contains small groups showing the nesting habits of a number of our common birds, among them the phalarope, oriole, flycatcher, robin, tanager, vireo and quail.

\section{SOUTH CENTRAL WING}

\section{Bird Groups}

Here are the "Habitat Groups" of North American Birds. This unique series of groups shows the habits of some typical American birds in their natural haunts. The groups have been prepared under the immediate direction of Frank M. Chapman, Curator of Ornithology, who collected most of the specimens and made practically all of the field studies necessary for their reproduction. In the course of this collecting, he traveled more than 60,000 miles. The backgrounds are reproductions of specific localities, painted from sketches made by the artist who usually accompanied the naturalist when the field studies for the groups were made. Practically all sections of the country are represented, thus the series not only depicts characteristic bird life of North America but characteristic American 
scenery as well. The backgrounds of the groups were painted by Bruce Horsfall, Charles J. Hittell, J. Hobart Nichols, Carl Rungius, W. B. Cox and Louis A. Fuertes. The artificial foliage and flowers were made in the Museum laboratories from material collected in the localities represented. Each group is fully described in the label attached to the case. See also Guide Leaflets No. 28, No. 1 and No. 22. Beginning with the case at the right of the entrance and passing on to the right around the hall, we find the groups arranged in the following sequence:

The distribution of birds, notwithstanding their powers of flight, is limited in great measure by climate. Thus in traveling from Panama

Orizaba

Group

north to Greenland there are zones of bird life corresponding to the zones of temperature. This condition is illustrated in the mountain of Orizaba in Mexico, where in traveling from the tropical jungle at its base to its snow clad peak the naturalist finds

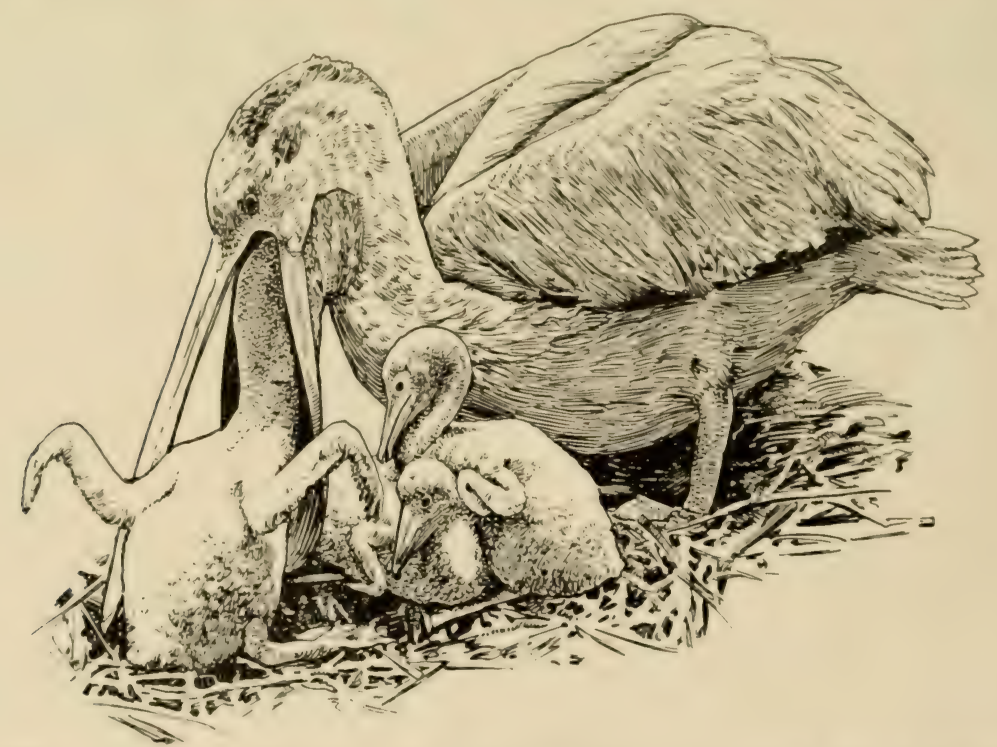

White pelican from Klamath Lake Group, Oregon. One young bird is illustrating its amusing method of procuring food from its parent's throat

zones of life comparable with those to be found in traveling north on the continent. Thus the Orizaba group so far as the distribution of life is concerned is an epitome of all the groups in the hall.

Among our most beautiful and graceful shore birds are the terns and Cobb's Island gulls, which (because of their plumage) have been so ceaseGroup lessly hunted and slaughtered for millinery purposes that now in their breeding places there are only hundreds where formerly there were thousands. The group represents a section of an island 
off the Virginia coast where the birds are now protected by law.

The duck hawk may be found nesting on the Palisades of the Hudson almost within the limits of New York City. It builds Duck Hawk Group nests on the ledges of the towering cliffs. This hawk is a near

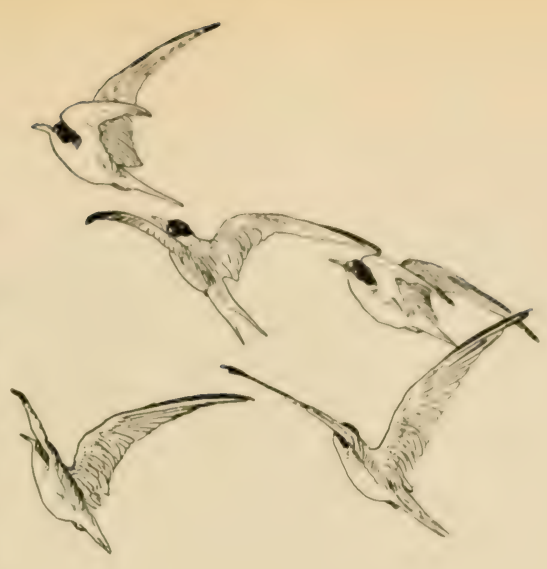

relative of the falcon which was so much used for hunting in the Middle Ages.

In August and September the meadows and marshlands in the vicinity of Hackensack, New Jersey, are teeming with bird life. In

Hackensack
Meadow Group the group showing these Hackensack meadows are swallows preparing to migrate southward, bobolinks or rice birds infall plumage, red-winged blackbirds, rails and the wood duck.

The wild turkey is a native of America and was once abundant in the wooded regions of the eastern portion of the United States, but is now very rare. It differs in color from Wild Turkey Mexican bird, the ancestor of our com
Group barnyard turkey, which was introduced from Mexico into Europe about 1530 and was

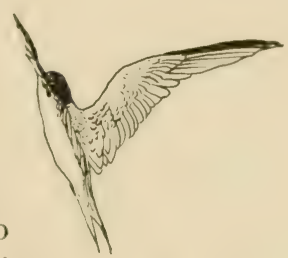
brought by the colonists to America. (Reproduced from studies near Slaty Forks, West Virginia.)

The great blue heron usually nests in trees. The bird flies with its neck curved back on its body and because of this habit can Blue Heron readily be distinguished from the crane with which it is Group frequently confounded. (Reproduced from studies near St. Lucie, Florida.)

In the "bonnets" or yellow pond lily swamps with cypresses and Water cabbage palmettoes, the shy water turkey builds its nest. Turkey or It receives the name "turkey" from its turkey-like tail and "Snake-bird" the title "snake-bird" from its habit of swimming with only Group near St. Lucie, Florida.)

The sandhill crane builds its nest of reeds in the water. Unlike the

Sandhill herons in this respect, it differs also in its manner of flight, Crane Group always stretching its neck well out when on the wing. (Reproduced from studies on the Kissimmee Prairies of Florida.) 


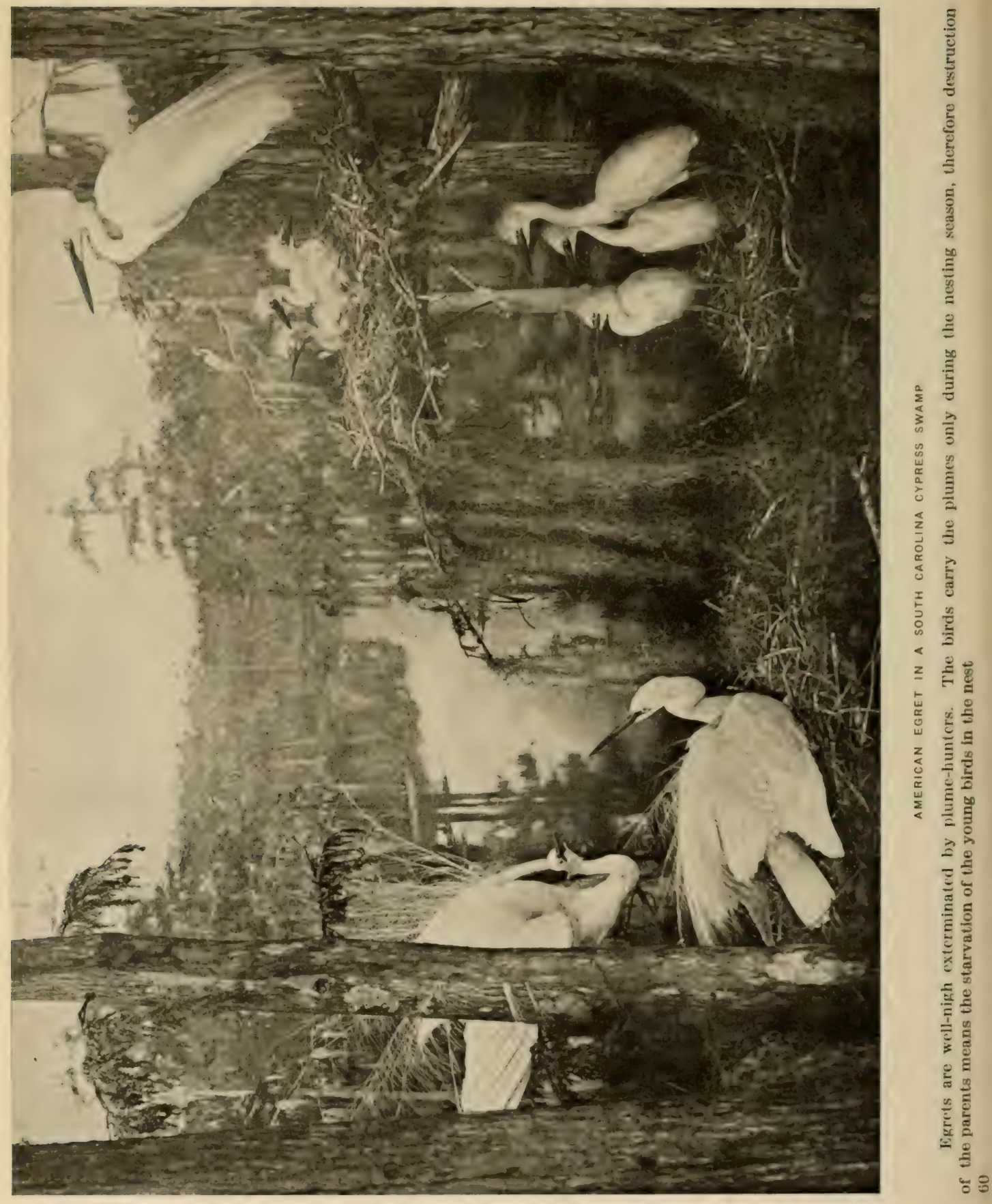


Pelican Island on the Indian River of Florida has been made a reservation by the United States Government, and these grotesque

Brown Pelibirds may now breed there undisturbed. The view shows a section of the island at the height of the nesting season. Notwithstanding the hundreds of young birds that are clamoring for food, observation has shown that the parent bird can pick out its own offspring with unfailing accuracy. (Reproduced from studies at Pelican Island, Florida.)

This beautiful bird has been brought to the verge of extinction in this country through the use of its "aigrette plumes " for millinery

Snowy Heron purposes, and is now confined to a few protected rookeries of or Egret Group the South. The birds have these plumes only during the nesting season, at which time the death of the parent means the starvation of the young. (Reproduced from studies in a rookery of South Carolina.)

The turkey vulture or buzzard is one of the best known birds of the Turkey VulSouth where it performs a valuable service in acting as the ture Group scavenger of the streets. On this account it is protected by law and by public sentiment and has become both abundant and tame. (Reproduced from studies at Plummer Island in the Potomac River, near Washington.

The California condor is the largest and one of the rarest of North American birds. It is not so heavy as the condor of the Andes

California Condor Group but has a slightly greater spread of wing, eight and one-half to eleven feet. In the group the visitor is supposed to be standing in the interior of the cave where the bird has its nest and is looking down on the river of the cañon which is more than five thousand feet below. (Reproduced from studies in Piru Cañon, California.)

The foreground of the group shows a detail of the island that is painted in the background. The young birds are feeding and

Brandt's

Cormorant Group it will be noticed that one fledgeling is reaching well down the mother's throat after the predigested food. (Reproduced from studies at Monterey, California.)

Formerly this area was an arid place with a characteristic desert bird

\section{San Joaquin} Valley Group fauna. Now the ranchmen have irrigated the land and aquatic bird life abounds. This group is a good illustration of the influence of man on the bird life of a region.

In the breeding season the flamingos congregate in great numbers in their rookeries. There were estimated to be two thousand nests in this colony. The flamingos construct their nests by scooping up mud with 


\section{Flamingo}

Group

their bills and packing it down by means of bills and feet. The nests are raised to a height of twelve or fourteen inches; this protects eggs and young from disasters due to high water. Only one egg is laid in the nest, and the young is born covered with down like a young duck and is fed by the mother on predigested food. The brilliant plumage of the adult is not acquired until the fifth or sixth month. (Reproduced from studies in the Bahama Islands.)

In this group is shown a portion of a coral islet on which

Booby and Man-of-War Group three thousand boobies and four hundred man-of-war birds were nesting, the former on the ground, the latter in the sea grape bushes. (Reproduced from studies in the Bahama Islands.)

The abundance of bird life in one of these rookeries is quite astounding. In this group are roseate spoonbills, snowy egrets, Ameri-

Florida

Rookery Group can egrets, little blue herons, Louisiana herons, ibises, cormorants and water turkeys. Because of the great inaccessibility of this island it has been one of the last places to escape the depredations of the plume-hunter. (Reproduced from studies in the Everglades of Florida.)

The golden eagle is one of the most widely distributed of birds. In North America it is now most common in the region from the Rockies Golden Eagle to the Pacific coast, although it is found as far east as Maine. Stories to the contrary notwithstanding, the eagle never attacks man even though the nest is approached. Its food consists of rabbits, squirrels, woodchucks and occasionally sheep. (Reproduced from studies near Bates Hole, Wyoming.)

The abundance of bird life in this western lake beneath Mt. Shasta, which is seen in the center of the background, is astonishing. Here is an

Klamath Lake Group example of how the normal nesting habits of a bird may be changed by its being driven into a different locality. In the group are white pelicans which usually make a nest of pebbles, Caspian terns which commonly build their nests on sand, and cormorants that nest on rocks, all nesting together here on the tule or rush islets of the lake. (Reproduced from studies at Klamath Lake, Oregon.)

The scene represented in this group is above timber line on the crest of the Canadian Rockies - 8,000 feet above the sea. AlArctic-Alpine though these mountains are in the temperate region the Group altitude gives climatic conditions that would be found in the far north, and the bird life is arctic in character. Here are nesting the white-tailed ptarmigan, rosy snow finches and pipits. (Reproduced from studies in the Canadian Rockies.) 


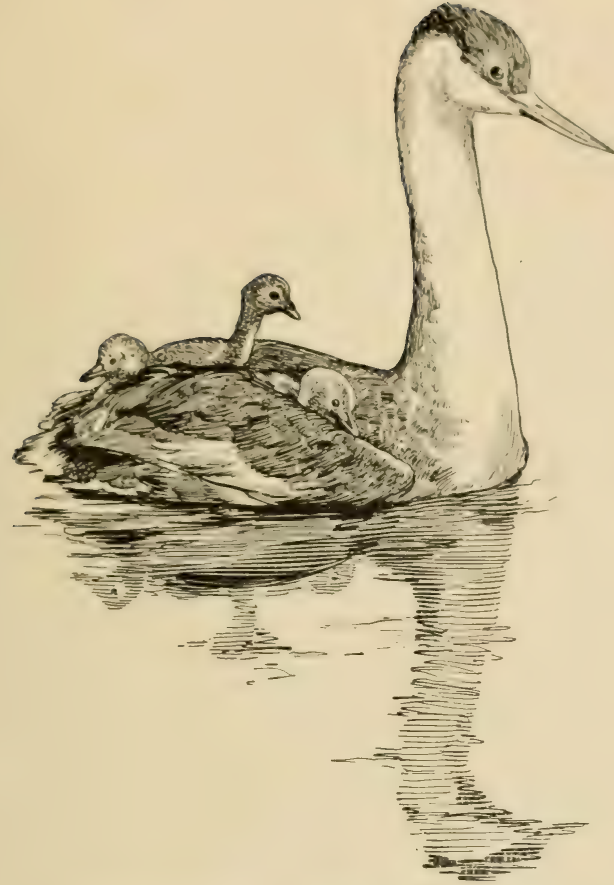

A grebe swims in stately fashion, while, peeping from the warm cradle of her back, eager, contented young birds take a sail with her

even before the ice is melted. To secure the young birds for this group it was necessary to hatch the eggs of the wild goose under a hen, so difficult is it to find the young in nature. (Reproduced from studies made at Crane Lake, Saskatchewan, Canada.)

The grebe is another of our aquatic Grebe Group birds which builds its During the incubation period the parent bird usually covers the eggs with grass and reeds when leaving the nest. Nesting at the same lake with the grebe was the red-head duck, which lays from fifteen to twenty eggs. (Reproduced from studies made at Crane Lake, Saskatchewan, Canada.)

The loon is justly famed for its Loon Group $\begin{aligned} & \text { skill as a diver, and can } \\ & \text { swim with great speed }\end{aligned}$ under water. Its weird call is a

This group shows a stretch of western plateau covered with sage bush. In this Sage Grouse Group bush is seen the male sage grouse strutting and wooing a mate. (Reproduced from studies at Medicine Bow, Wyoming.)

The prairie chickens are akin to the common grouse.

The group represents a typical scene during the mating season. The

Prairie Chicken Group male birds go through most surprising antics in their efforts to attract the females. They inflate the orangecolored sacs on the sides of their necks, dancing and strutting about and uttering a loud resonant booming note. (Reproduced from studies near Halsey, Nebraska.)

The wild goose is one of the first birds to migrate north in the spring. It nests in the lakes of Canada

Wild Goose Group

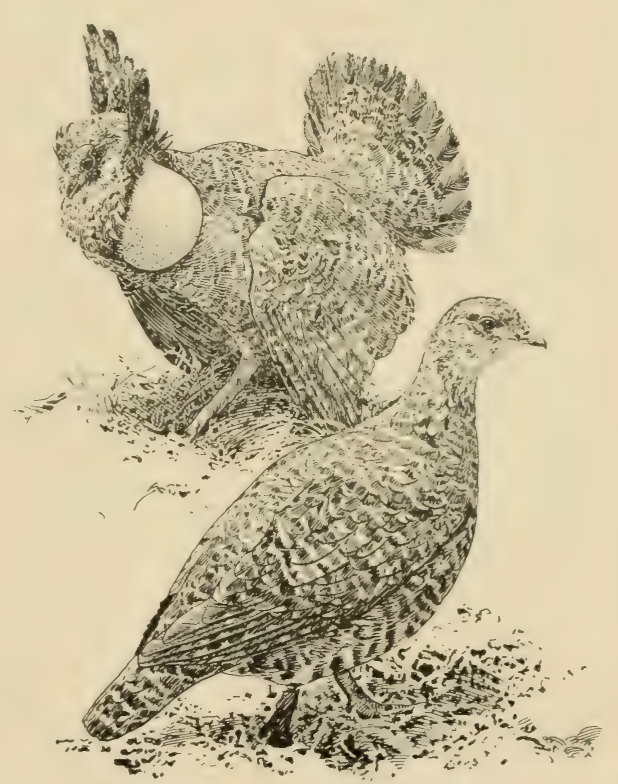

Love making of the prairie chicken. In this position and with orange-like air sacks inflated, he produces a booming sound which may carry a distance of two miles 
familiar sound on the northern New England lakes. Many loons pass the winter at sea fifty miles or more from land. (Reproduced from studies at Lake Umbagog, New Hampshire.)

This rocky island thirty miles from shore in the Gulf of St. Lawrence

Bird Rock Group affords some protection to the sea birds which still nest in great numbers on and in its cliffs, although the colony is a mere shadow of what it was even fifty years ago. Seven species are shown nesting in the group. Namely the razor-billed auk, petrel, gannet, puffin, Kittiwake gull, common murre and Brünnich's murre. (Reproduced from studies at Bird Rock, Gulf of St. Lawrence.) [A description of the Bird Rock Group is given in Guide Leaflet No. 1.]

[Return to the South Pavilion containing the apes and monkeys.]

\section{WEST CORRIDOR}

\section{LOCAL BiRDS}

Returning to the South Pavilion where the monkeys are and passing to

Seasonal

Collection of Birds

the right, we enter the West Corridor containing the collection of local birds. At the south end of the corridor are several cases in which the birds are changed each month to represent the bird life of the parks of the city. This exhibit is particularly useful for teachers and to those desiring to identify the birds which they see out of doors. Other exhibits which will appeal to the bird student are those showing types of feet, bill, wings and feathers. Variation of a species, that all important factor of evolution, is here illustrated in the geographical variation in size and color of the song sparrow. [See Guide Leaflet No. 22.]

The group near the stairway showing the feeding habits of birds, emphaBird Feeding
Group sizes the remarkable manner in which the bill of the bird is adapted to secure food. For instance the humming bird which feeds to a considerable extent on the nectar of flowers, has a long, slender bill; the birds of prey like the owl or hawk, have short, curved bills for tearing flesh; the seed-eating birds like the parrot, have thick, heary bills, while the water-feeding birds like the duck, have broad, spoon-shaped bills.

The collection of Auduboniana, or objects relating to the life and work Auduboniana of John J. Audubon, occupies the stairway wall. It comprises original sketches and drawings of Audubon and his sons and was presented to the Museum by his granddaughters. 


\section{SOUTHWEST WING}

\section{Indians of South America}

Passing through the west corridor of local birds and on into the adjoining hall to the west, we find the collections relating to the Indians of South America. The greater part of the hall is filled with South Amer- material from Peru, Bolivia, Ecuador and Chile, illustrating ica $\quad$ the various forms of culture that prevailed in the empire of the Incas. These Indians, together with the Mexican Indians,

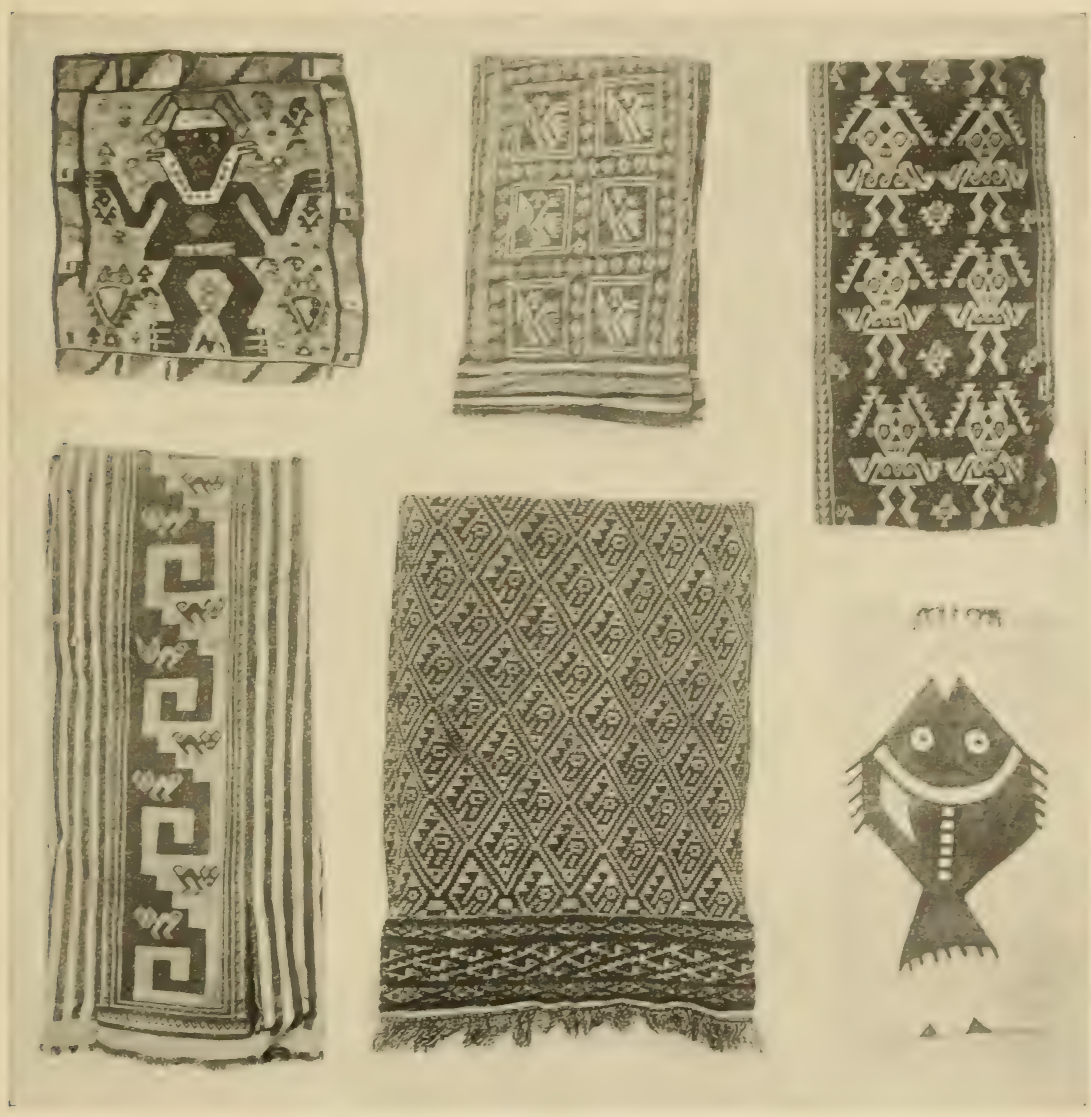

PIECES OF CLOTH FOUND WITH PERUVIAN MUMMIES

The only sources of knowledge of prehistoric Peruvians come from their graves. They were familiar with most modern weaves including the finest gobelins and produced highly decorative effects by harmonized colors and a repetition of woven-in designs. The Museum's collection of mummy cloths is perhaps the largest in the world, and is not fully known, for a large number of the mummy bundles have never been opened 


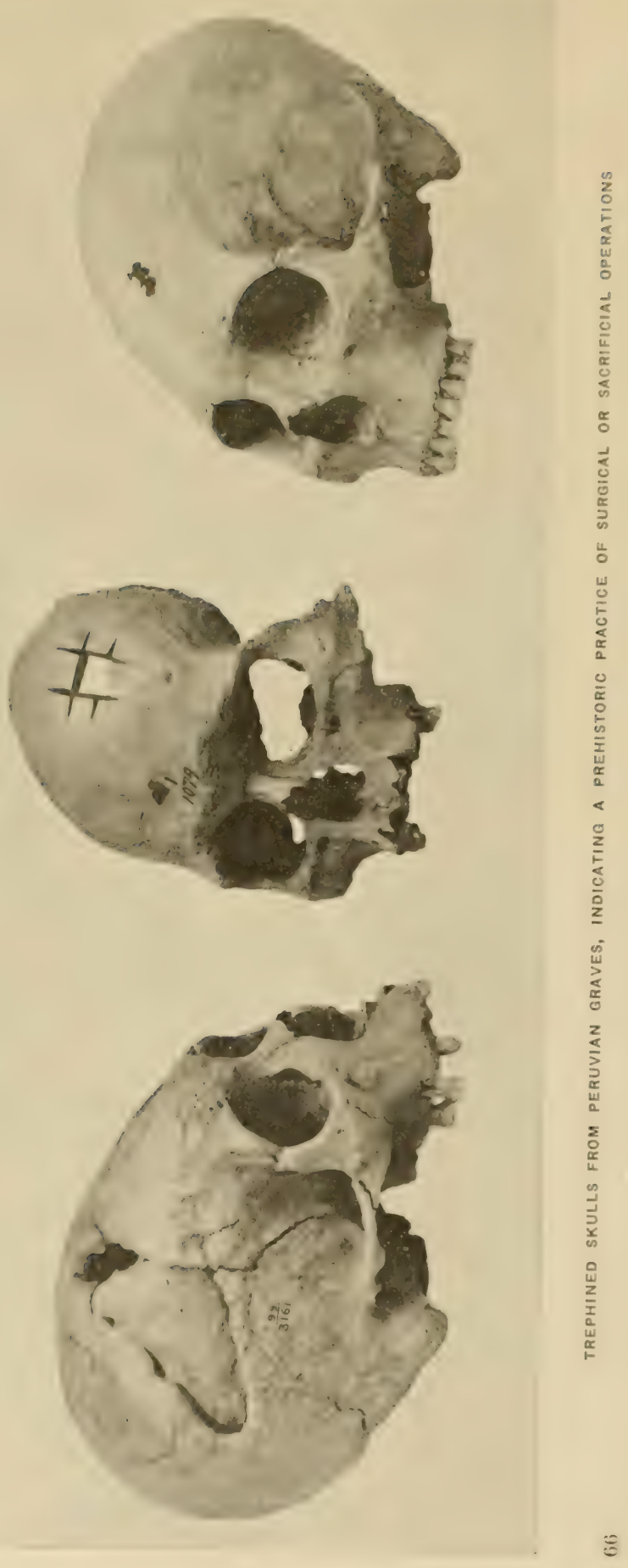


attained the highest type of civilization on this continent in prehistoric times. Unlike the Mexicans however, they had no written language. They were tillers of the soil and raised maize, potatoes, beans, coca and cotton. The Incas domesticated the llama, which was used as a beast of burden. They excelled in the manufacture and decoration of pottery vessels, in metalwork, and in textile fabries. In the case directly in

Gold and

Silver front of the entrance are displayed gold and silver objects such as beads, cups, pins and earrings which show the skill of the Incas in the beating, soldering and casting of metals.

In weaving they were perhaps preëminent among prehistoric peoples, many

Textiles of their specimens exhibiterl here being unsurpasserl at the present day. The materials used were cotton and the wool of the llama, alpaca and vicuña. In the first cases on the right are examples of these textiles with looms and shuttles. [The musical instruments of ancient Peru are discussed in Guide Leaflet No. 11.]

The alcove cases are geographically arranged, showing exhibits from the north toward the south of South America, then up into the interior of the continent. The two-spouted drinking cups, copperwork, slings such as are still in use, portrait jars, vessels upon which the decorations represent fruit and vegetables and scenes from daily life, and black pottery, are all prehistoric and a number of the specimens are of rare beauty as well as raluable from an archæological standpoint.

The collections in the gallery rail cases include quipos used to keep accounts, various kinds of corn which with the lima bean and potato have been introduced into our country from Peru; charms and medicines, coca which was chewed, and maize which was used to make the national drink chicha. A number of the chicha jars are on exhibition on top of the wall cases at the east end of the room.

The mummy in the case at the west end of the room was found at Chilean
Mummy Chuquicamata, Chile, and is the body of an Indian which has been remarkably preserved by nature. This Indian may have met his death by the caving in of some mine, and in the dry climate of the region the tissues of the body have been so thoroughly impregnated with copper salts that the original form of the man is retained.

On the north side of the wall are the ethnological collections from Brazil, British Guiana, Paraguay and Colombia. War implements, basketry, featherwork and musical instruments are arranged in these cases. One case contains skulls which evidence most extraordinary skill in trephining.

Trephined Skulls
For ritualistic purposes or for cures or for some other unknown reason, this supposedly modern surgical operation was successfully performed. Many of the tribes deformed their 
skulls, this undoubtedly being considered a mark of beauty. It necessitated the binding of the head in infancy.

The wall case at the left of the entrance contains mummy bundles, showing the burial customs of the Peruvians. In no part of America are

Mummy Bundles found so many and so extensive burial places as in the coast region of Peru. Here were interred countless thousands of the ancient dead. In the huacos or graves, with the bodies, were placed such articles as had been most useful and highly prized during life, and such it was considered would be most serviceable in a future life.

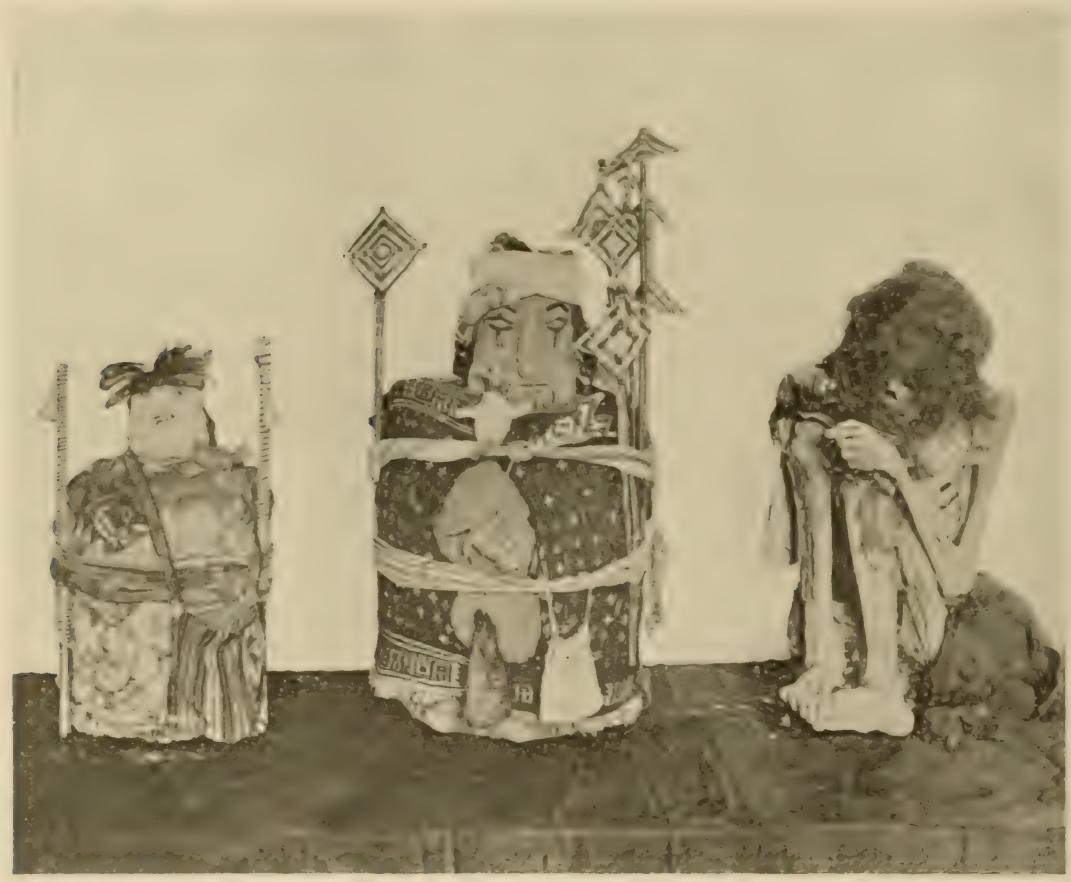

PERUVIAN MUMMY BUNDLES AND MUMMY

The ancient Peruvians wrapped their dead in fabrics of fine linen and wool, then covering with a sack of strong cloth. The mummy "bundle" thus produced was often given a "false head" of cloth filled with vegetable fibre. Climatic conditions in Peru have preserved these mummies and their wrappings during many centuries

To this custom we are indebted for no small part of our knowledge of the daily life of the ancient Peruvians. From the mummy bundles and graves all the olojects in the extensive collections in this hall, illustrating the civilization of the Incas, have been obtained. The wonderful state of 
preservation shown in the textile fabrics and other perishable materials from the coast regions is due to the extreme dryness of the climate and the nitrous character of the soil. [See Guide Leaflet No. 24.]

\section{SOUTHWEST PAVILION}

\section{Chinese and Siberian Collections}

If we pass on into the hall at the extreme west end of the building, we Collections find specimens showing collections from Asia. The arrangefrom Asia ment is geographical. Read carefully the label at the entrance to the hall. Specimens illustrating the culture, industries, religion and manufactures of China are on the left; others showing the mode of living, the costumes and the war implements of Siberia are on the right. Bamboo, porcelain, basketry, inlaid work, cloisonne enamel, agricultural implements, carvings in wood, ivory and stone, and embroidery are shown to advantage. The furwork, costumes and rugs of the people of East Siberia reveal remarkable skill in workmanship. Two models show respectively summer and winter scenes in Siberia. A small model in one of the cases to the left shows the manner of making pottery. A series of frames in the rear contain pieces of various kinds of fabrics and patterns illustrating weaving and woodwork ornaments.

\section{WEST WING}

\section{SHELls}

The collection of shells is being installed in the West Wing and is not yet open to exhibition. It contains altogether about 100,000 specimens representatives of nearly 15,000 species. These show extraordinary range of color and ornamentation. The arrangement of the collection is still incomplete but the installation will be as follows: first, in the south wall cases will be placed a series showing briefly the classification of mollusks; second, in the eight table cases at the north and south ends of the hall the collections of land shells; third, in the upright railing cases the bivalves or mollusks which have two shells like the common clam; fourth, in the metallic cases the univalves, mollusks which have only one valve or shell like the snails; fifth, special exhibits of shells in the north wall cases. Other cases will contain exhibits illustrating the anatomy and habits of mollusks; colored transparencies will show them in their habitats.

[Return to the South Pavilion containing the apes and monlieys.] 


\section{SOUTHEAST WING}

\section{Mamals of the WURLD}

Continuing east from the hall where are the apes and monkeys, we pass the elevators, to enter the hall of the Southerast II ing, devoted mainly to mammals of the world. The exhibits read like the pages of a book

Mammals of the World from left to right, being arranged to bring out the phylogeny or past history and development of the chief divisions of mammals. The specimens are arranged not on shelves but close against the background of the case on small projecting supports and from each a cord has been stretched down along the background to a diagrammatic representation of the geological periods. In this way are indicated the relationships of the various animals to one another as well as the geological age in which each animal probably originated. Circling the hall above the cases is a mural frieze representing marine scenes, which serves as a background for groups of porpoises, dolphins and other small members of the whale family. The most striking object in the hall is the life-size model of a sulphur-bottom whale, seventy-nine feet in length. The

Model of original of this specimen was captured in Newfoundland and Sulphur- the model is accurately reproduced from careful measurements. bottom As can be seen by examining the models of a whale's head Whale attached to the pillar, the whalebone which takes the place of teeth hangs in great plates from the inside of the upper jaw. This whalebone acts as a strainer in the mouth of the whale and extracts the small animals from the sea water which the whale takes into his mouth when feeding. The food consists mostly of tiny crustaceans less than an inch in length. Although whales and porpoises live in the water they are not fishes, but are warm-blooded and breathe by means of lungs, not gills. The whale must come to the surface to breathe and the so-called "spouting" is merely the result of the warm air being expelled from the lungs when he breathes. A whale does not spout water as is commonly supposed. Models to scale of the other whalebone whales, and the toothed sperm whale, and skeletons of the smaller whales are hung near for comparison.

The case along the gallery rail contains insects of many kinds which are placed here temporarily - butterflies, moths, beetles, spiders, locusts, katydids, etc., in infinite variety. Protective coloration and mimicry are well exemplified.

\section{SOUTHEAST PAVILION}

HALL OF INSECT LifE

Proceeding east, we enter the Insect Hall. The installations in this hall point out the relationships, through origin and mode of life, of insects to 70 
each other and to the other members of the Animal Kingdom, especially to Insect Life man. The exhibits are arranged in a continuous series, and are numbered so that we can easily follow the plan beginning at the pillar farthest to the left.

First is an introductory section illustrating by diagrams the importance Importance of insects as shown (a) by the large number of species comof Insects pared with other animals [there are more species of insects than of all other animals put together] and (b) by their great influence on human interests. In the Lnited States, the economic loss by insects is more than five times as great as by fire and there are more than twelve times as many deaths from insect-borne diseases as from railroad accidents. On the other hand, many of our crops and all beautiful flowers are largely dependent upon pollination by insects.

Next in order is given an outline of the development of insects as a race, Evolution as their geological history, anatomy, physiology and embryology. Illustrated Then begins a graphic discussion of the principles underlying by Insects evolution as illustrated by insects.

Turning to the table cases at the northeast corner of the room, we find photographs of prominent American entomologists; also short biographies and bibliographies which form an introduction to the more detailed study of insects. One case is devoted to collecting apparatus and one to the classifieation of insects and their allies with typical specimens to illustrate each Insect Habits group. Another case treats of insect architecture. Others show how insects pass the winter, how they lay their eggs, catch their prey, etc. Collections of insects from particular environments and at special seasons hint at the interesting studies to be made along these lines.

Then come a series of exhibits concerned with the enemies of insects

\section{Insects}

and Man ending with man and showing how insect pests are combated. Another side of the question is then taken up; the carrying of disease by insects. Household insects, aquatic insects and insects which live underground in plants and on their leaves (including some fine models of plant galls produced by insects) are also shown. Beneficial insects such as the silk worm and honey bee are treated in some detail, and in connection with the latter are taken up social insects in general.

Visitors desirous of studying specimens of local insects more in detail are

Local Collection cordially invited to do so by consulting the nearly complete collection to be found in this hall under the custody of the New York Entomological Society.

[Return to the elevators and ascend to the Fourth Floor.] 


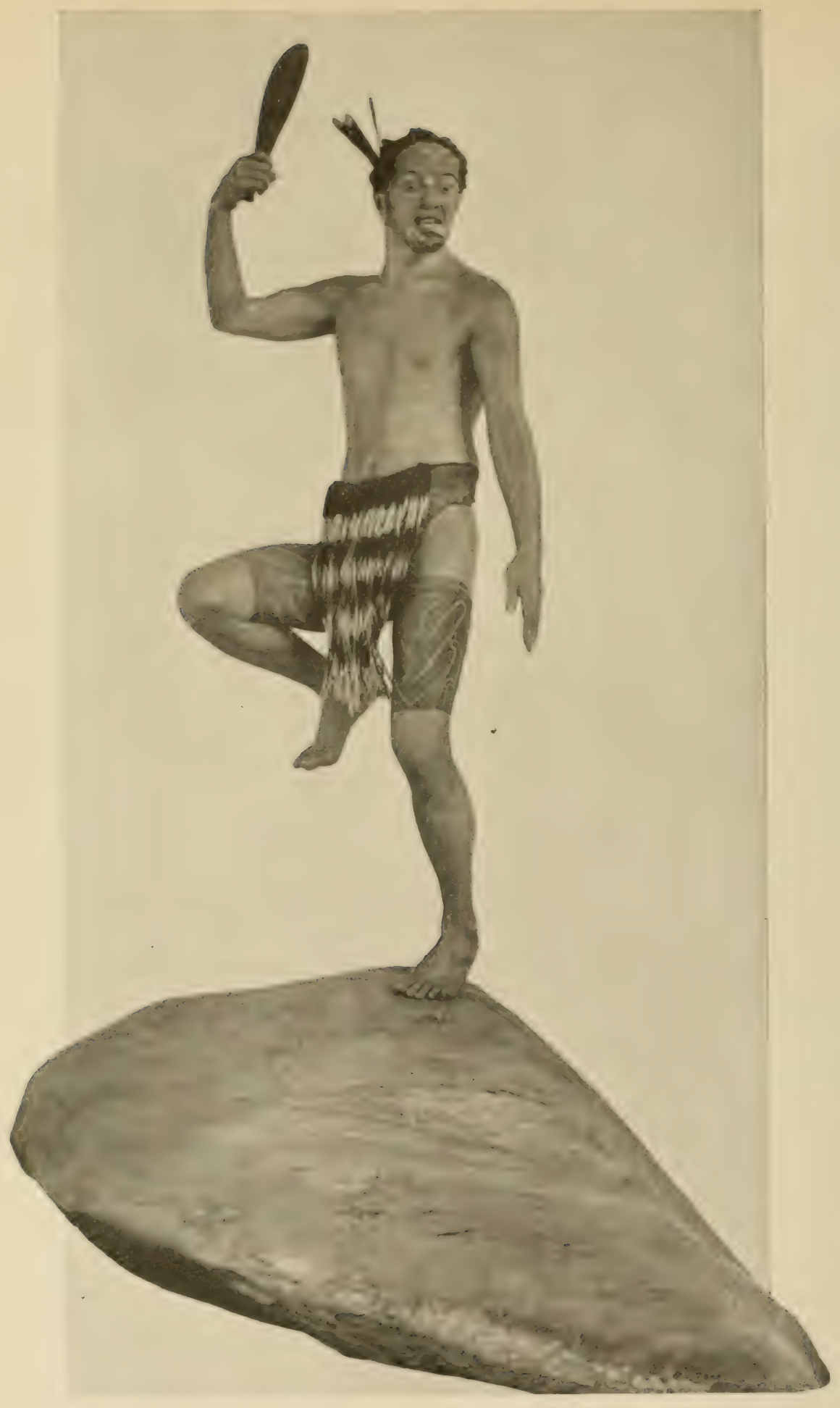

THE MAORI WARRIOR

Cast from a living Maori in the pose of a deflant warrior. The boulder of jade on which the figure stands is the largest that has ever been brought from New Zealand 72 


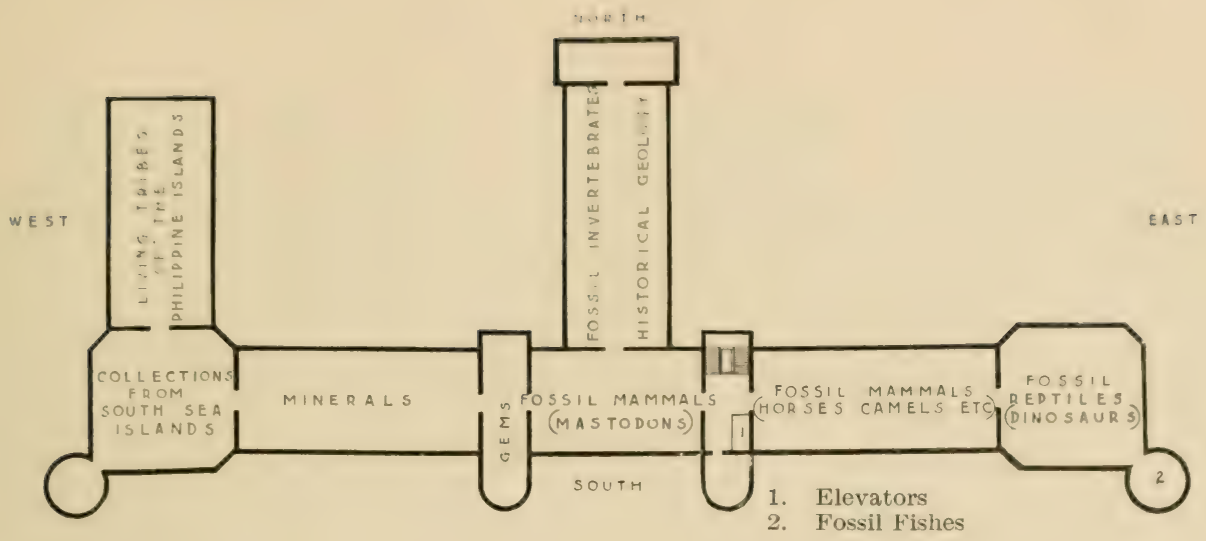

FOLRTH FLOOR

Foremord on Fossil Tertebrates

In the East Corridor, and the South Pavilion at the left, as well as in the East Wing and Southeast Pavilion at the right are displayed the fossil mammals, reptiles and fishes.

In a general way, fossils are the petrified remains of plants or animals that lived at some past period of the earth's history. In many instances we have not the objects themselves but only their casts or impressions in the rocks. This is particularly the case with shells. Sometimes, as with the bones of the great Irish elk the objects have been buried in swamps or bogs, and in a few rare instances as with the mammoth and woolly rhinoceros, entire animals have been preserved for thousands of years in ice or frozen mud. Fossils are found in localities where the dead animals or plants have gradually been buried under layers of sediment to such a depth that they come in contact with the mineral waters of the earth and finally become petrified. Later through subsequent upheaval and erosion they are again brought to or near the surface of the earth. Petrifaction is the slow replacement of animal or vegetable material by such minerals as carbonate of lime or silicate. The process is very slow and for this reason flesh is never petrified. Fossil beds are found in every continent. In our own country, Texas, Montana, Wyoming, and the Bad Lands of South Dakota are famous for their large fossil beds, and many of the finest and rarest fossils in the Museum were obtained in these localities.

As it takes thousands of years for the various layers of earth to accumulate over the bones, and for the latter to become petrified, the study of fossils and the strata in which they are found is an important aid in determining the age of the earth and the succession of life thereon. Nearly 
all of the skeletons exhibited in these halls are of animals which lived from 30,000 to $20,000,000$ years ago. To prepare a specinen for exhibition the matrix in which the bones are imbedded is carefully chipped away and the missing parts restored in cement and plaster. The bones are then assembled as in life. In the specimens on exhibition the restored parts differ in color from the original parts of the skeleton and can readily be distinguished.

As a whole, the Museum collections of fossil vertebrates are believed to be the finest in the world, if we take into consideration not merely numbers, but also variety, quality and perfected methods of preparation and exhibition. The collections illustrating the evolution of the horse are probably equal to those of all other institutions combined. The collections of Permian reptiles, of Jurassic and Cretaceous dinosaurs, of turtles, of North American Tertiary mammals, and of extinct mammals of South America, are likewise of the first rank. There are more than seventy complete skeletons on exhibition, several hundred skulls and nearly two thousand jaws or other parts of various species. About ten times this number are in storage, reserved for study and research, or not yet prepared for exhibition.

\section{WEST CORRIDOR}

\section{Fossil Fishlike Lizards}

Directly in front of the elevator is a wall case in which the most recently acquired specimens are placed. The cases attached to the wall near the stairway contain specimens of huge marine fishlike lizards, which show the tremendous pressure to which fossils are often subjected and the fragmentary condition in which they are found.

\section{SOUTH PAVILION}

\section{Mastodons and Mammoths}

The visitor should first enter the South Parilion in which are shown the skeletons of mammoths and mastodons, the prehistoric relatives of the modern elephants, and of the curious and extraordinary extinct animals which inhabited south .meriea in prehistoric times, 30,000 to 100,000 years ago. On the left is a series of modern skeletons illustrating the evolution of the horse under the hand of man. Here are such extremes as the Shetland pony, 


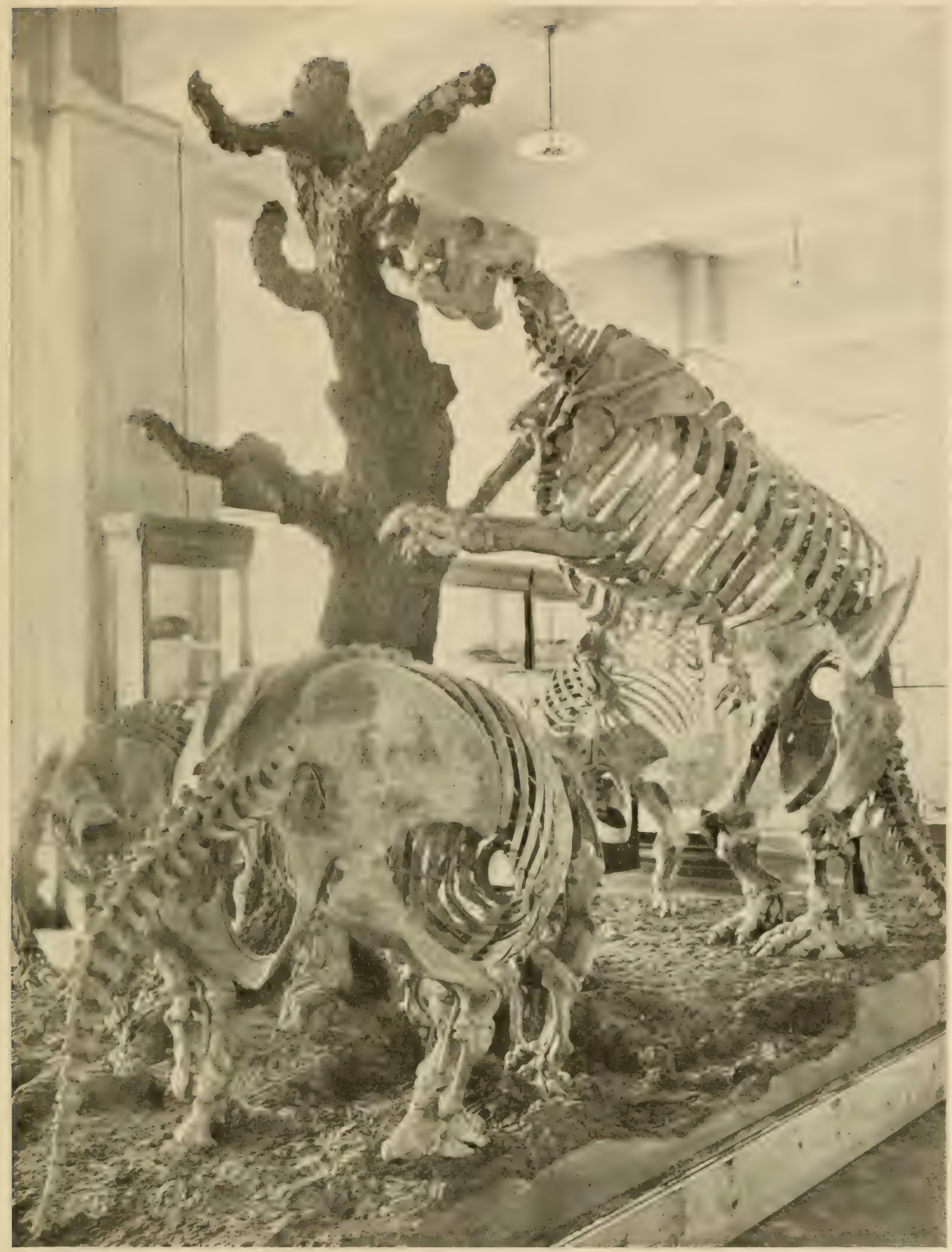

THE GROUP OF GIANT GROUND SLOTHS

Fossil mammals from South America adapted for digging about the roots of trees for the purpose of pulling them down to feed on the leaves and twigs 
only two feet ten inches high, and the rough-boned draught horse, which stands six feet one inch in height. Contrast these with the slender-limbed "Sysonby" the famous race horse, and the Arabian stallion "Nimr." Man by his intelligence has modified the form of the horse to meet

Skeletons of Modern Horses his needs and hats accomplished in at small degree hut rapidl!?, what nature has done in an extensive way during long ages - as will be seen from the fossil horses in the next hall. The similarity in structure of the skeletons of horse and man is brought out in the exhibit of a rearing horse being controlled by man. A comparison of these two skeletons will show that with some modification the bones of the one correspond with the bones of the other. The horse lover will also be interested in the osteological collections in the wall cases which show how to tell the age of horses through the growth and development of the teeth.

Beyond the horse exhibit on the left are fossils from South America, the most striking of which is the group of giant ground sloths. There are also good examples of the Glyptodon, a sort of gigantic armadillo with its

Fossil

Mammals of South America peculiar shell-like covering, the saber-toothed tiger and other singular extinct animals peculiar to South America. Although these animals were contemporaneous with the North American mammals of this period, they are so different in structure from any other known mammals, that it is practically certain that during their evolution South America was an island continent without land connection with North America.

The principal exhibits on the north side of the hall are the mammoths and mastodons and the series of skulls showing the evolution of the elephants. The "Warren Mastodon" is a classic specimen. It was found

Warren Mastodon near Newburg, N. Y. in 1846, and is the finest specimen of its kind that has ever been discovered. While to the lay mind mastodon and mammoth are one, note that there are as great differences between them as there are between a deer and a moose. The mammoth and the mastodon were almost world-wide in their distribution, their remains being found on every northern continent, those of the mastodon in South America also. The modern elephants are confined to a limited area in India and Africa. While modern elephants are not direct descendants of the American elephants, they have originated from species in Asia which were contemporaneous with the mammoth and mastodon. Without any doubt prehistoric man hunted these animals. 


\section{SOUTHEAST WING}

\section{Fossil Mamals of the Tertaky Period}

Return to the East Corridor and continue into the Southeast II"ing or Tertiary Hall which contains the Fossil Mammals of the Tertiary Period.

The geological age to which all the fossils shown in this hall belong, covers a period of from 100,000 to $3,000,000$ years. At each side of the entrance are charts indicating the successive periods of time from the Triassic to the Tertiary, and the animal life which pertained to each. Careful guides and exhaustive cards of explanation, photographs, and window transparencies combine to make the entire exhibit illuminative and interesting.

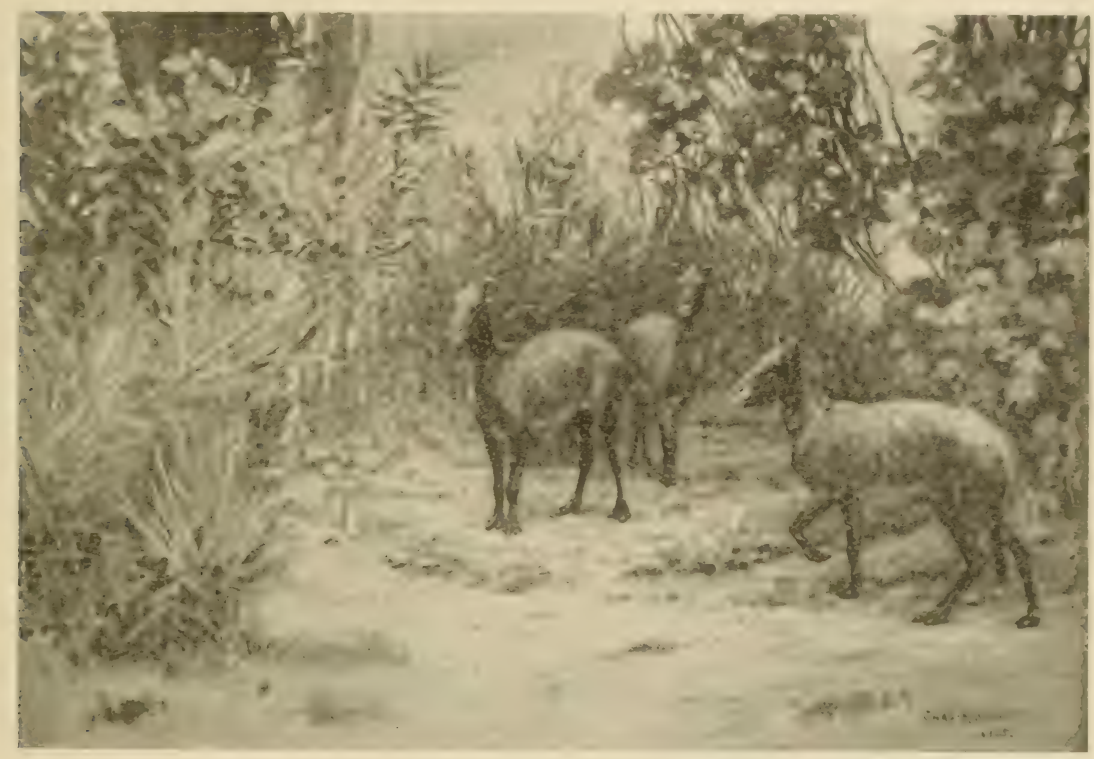

Restoration of Eohippus, the four-toed horse. This ancestor of the modern horse, scarcely larger than the red fox, lived some three millions of years ago. It comes from the Lower Eocene of Wyoming and New Mexico

The particular gem of this hall is the wonderful series in the cases by the entrance and in the first alcoves on the right showing the evolution of

Evolution of the Horse the horse in nature. The Museum is justly proud of this collection. Not only is it the largest and finest series of fossil horse skeletons in the world, but it is larger than the combined collections of all other institutions, and it contains the earliest known ancestors of the horse, the little four-toed Eohippus, 


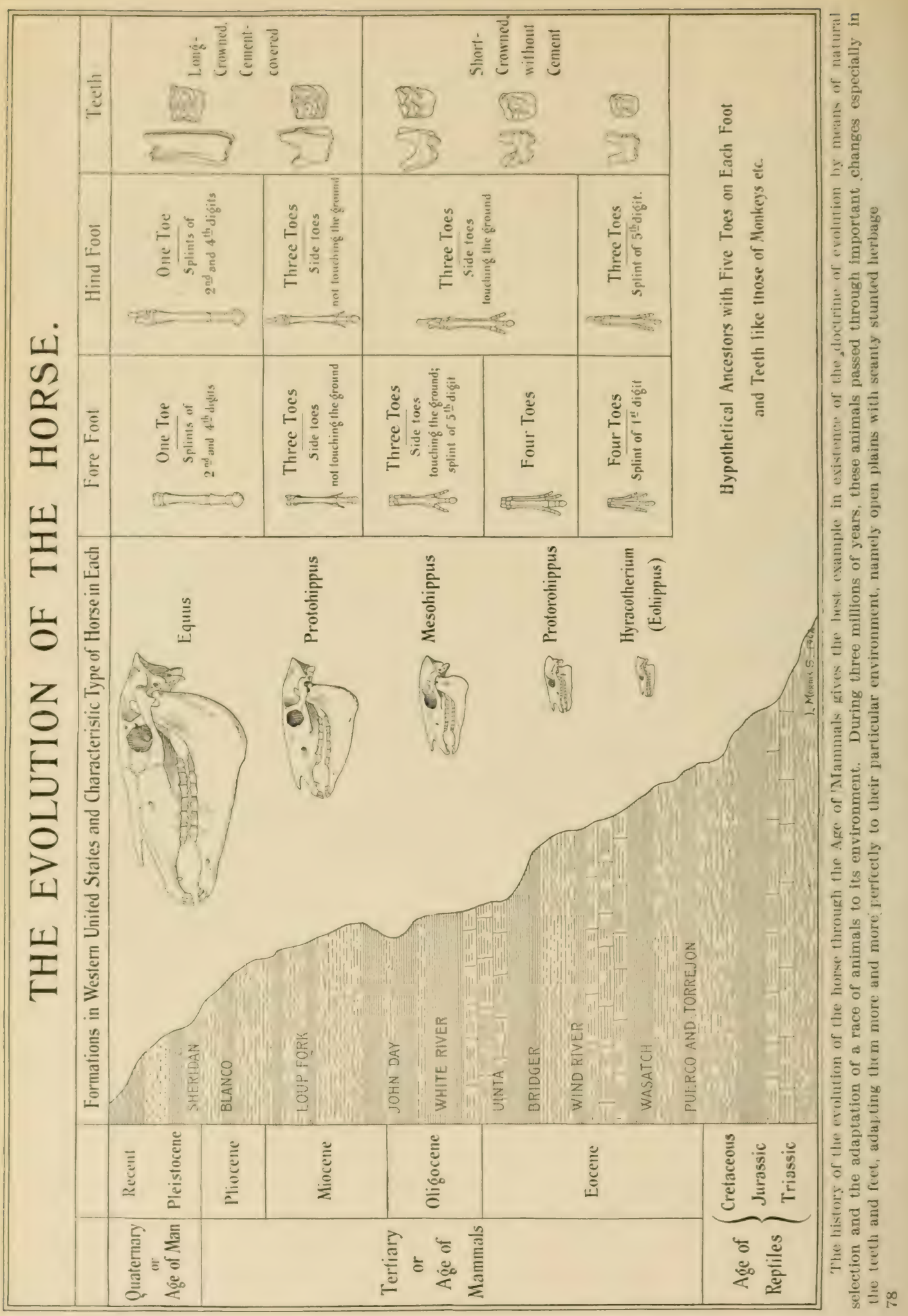




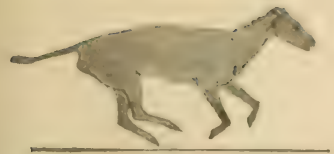

Eohippus

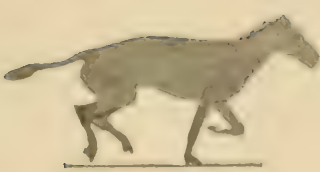

Orohippus

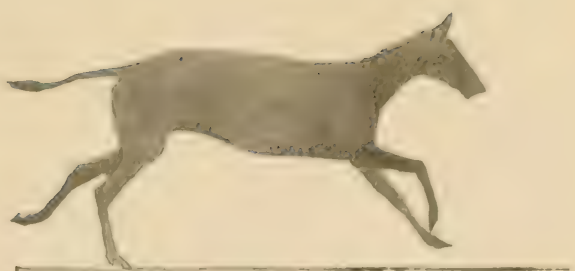

Mesohippus

which was no bigger than a fox and on four toes scampered over Tertiary rocks. As will be seen by an examination of the skeletons of the horse and man in the Quaternary Hall, the modern horse walks on the tip of his middle finger and toe. The front hoof bone corresponds to the last joint of the third finger in the human hand, and the other bones of the leg correspond bone for bone with the structure of the finger, wrist and arm of man. In the modern horse the remaining fingers or toes of the fore and hind foot have entirely disappeared, or remain only as vestiges, the so-called "splint bones." The structure of the modern horse shows that it developed from a five-toed ancestor. This ancestry has been traced back to the four-toed stage.

In the wall case at the right of the entrance is given a synopsis of the evolution of the foot and skull of the horse and the geological age in which each stage is found. Across the alcove the visitor will find the skeleton of Eohippus, the four-toed stage of the horse and the earliest form that has been discovered. This specimen is from the Wind River beds of Wyoming and may have lived $3,000,000$ years ago. It is interesting to note that while there were no horses found in this country by the white settlers, America is the original home of the horse.

Passing from skeleton to skeleton the changes that have taken place in the development of the horse are easily distinguished. The exhibit is made more lifelike by plaster restorations of the animals and by water-color sketches showing primitive horses in their environment. These paintings and models are by Charles R. Knight. In the later types of the three-toed stage the two lateral toes have lost their original function of support and are gradually become vestiges. The three-toed horse in the center of the alcove is one of the most complete and finest examples that has ever been unearthed.

Opposite the horse exhibit on the other side of the hall, are series of specimens illustrating the evolution of the camel, deer and the other clovenhoofed animals. These animals like the cow of to-day walked on the tips of the third and fourth fingers, and the gradual disappearance or reduction to useless vestiges of the other fingers and toes can be traced as in the horse series. 
A curious and rematriable instance of parallel evolution is furnished by Giraffe Camel the eases of the giraffe camel and the giraffe. The former and Giraffe wats descended from the primitive camel which lived in North Giant Pigs Imerical, while the giraffe had for its ancestor the primitive and Pygmy antelope of the (Old World; thus each species evolved indeHippopot- pendently of the other. The griant pigs, or elotheres and the amus pygmy hippopotamus will repay examination.

The primitive rhinoceros-like animals are shown near the center of the hall on the right. It seems hard to believe that our vast western country Rhinoceros and indeed all North America, was once the home of the

\section{re} rhinoceros. As here indicated vast herds roamed over the fields in the 'Tertiary Period and their fossil remains are found imbedded in the Plains of South Dakota. Opposite these are shown the ancestors of the dogs, cats and other carnivores, among which is the giant saber-toothed tiger.

On the south side on the right are skeletons of titanotheres, on the left of uintatheres, huge extinct, horned animals peculiar to North America.

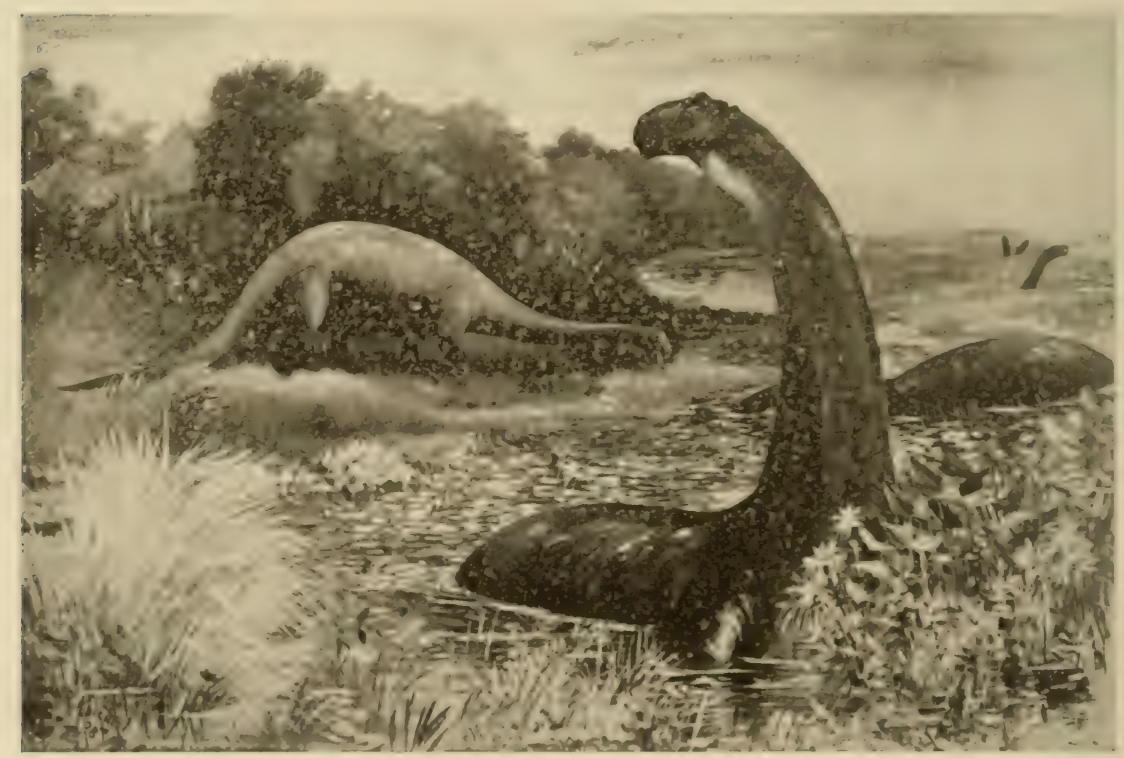

Restoration of Brontosaurus. One of the largest of the amphibious dinosaurs, coldblooded, slow-moving, unintelligent creatures that grew to large size (65 $\mathrm{ft}$. in length) in the rich vegetation of the Reptilian era 


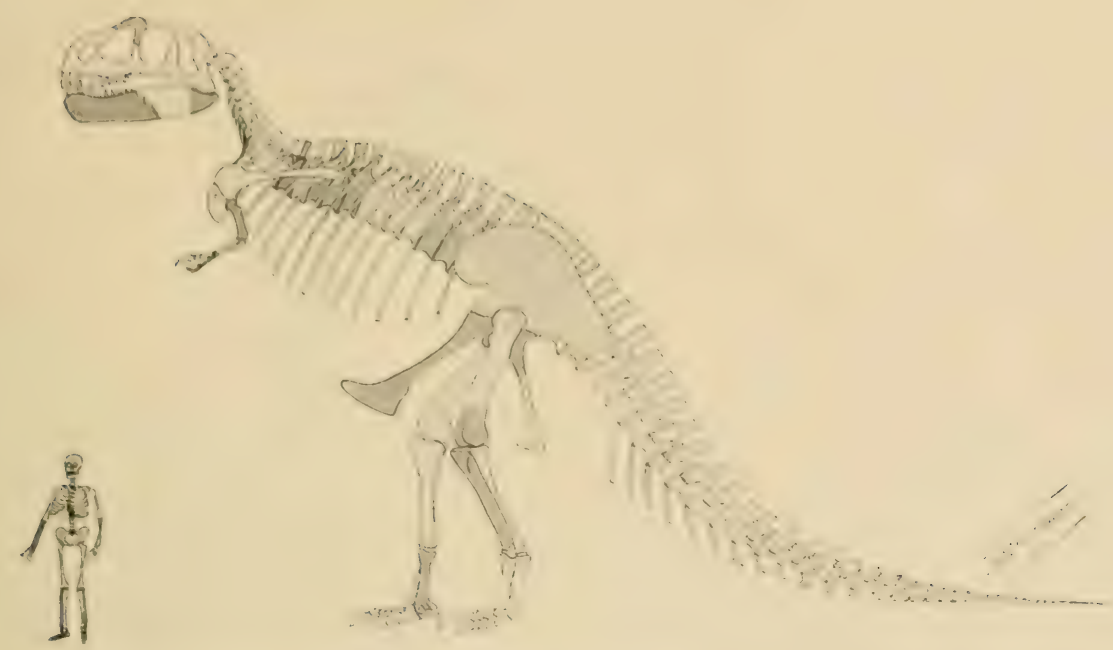

Rough drawing to show scale of size of Tyrannosaurus rex. This carnivorous dinosaur was the largest beast of prey that ever lived. The Museum possesses one Tyrannosaurus skeleton from South Dakota and two from Montana

\section{SOUTHEAST PAVILION}

\section{Fossil Reptiles and Fishes}

The visitor now enters the Southeast Pavilion containing the dinosaurs and other fossil reptiles and also fishes. These animals belong to a more ancient period than the specimens just examined. They lived from

The $3,000,000$ to $10,000,000$ years ago. They include the

Dinosaur Diplodocus well-known dinosaurs of which the Museum has a large collection. In the wall case on the left is a portion of the skeleton of the dinosaur Diplodocus; this was the first of these specimens to be unearthed by the Museum.

The gigantic skeleton in the center of the hall is the huge extinct reptile, the dinosaur Brontosaurus, found in the Jurassic beds of Brontosaurus Wyoming. It is the only mounted specimen of its kind in the world and more than two-thirds of the skeleton is the original petrified bone. It is sixty-six feet eight inches in length, sixteen feet in height and is estimated to have weighed when alive thirty-five tons. Brontosaurus is one of the largest giant reptiles and as is indicated by its teeth was herbivorous, probably living on the rank water weeds of the nearly sea-level marshes of Wyoming. Contrasted with the herbivorous Brontosaurus, is the carnivorous dinosaur Allosaurus, mounted to represent Allosaurus the animal feeding on the fallen carcass of a Brontosaurus, upon which it preyed. This is not a fanciful mounting for these very skeletons were found in close proximity to each other in the Jurassic beds of Wyoming, and the skeleton of the fallen Brontosaurus shows gouges made by the teeth of Allosaurus as it tore the flesh from its victim.

Near the Allosaurus group is a portion of a skeleton of Tyrannosaurus 


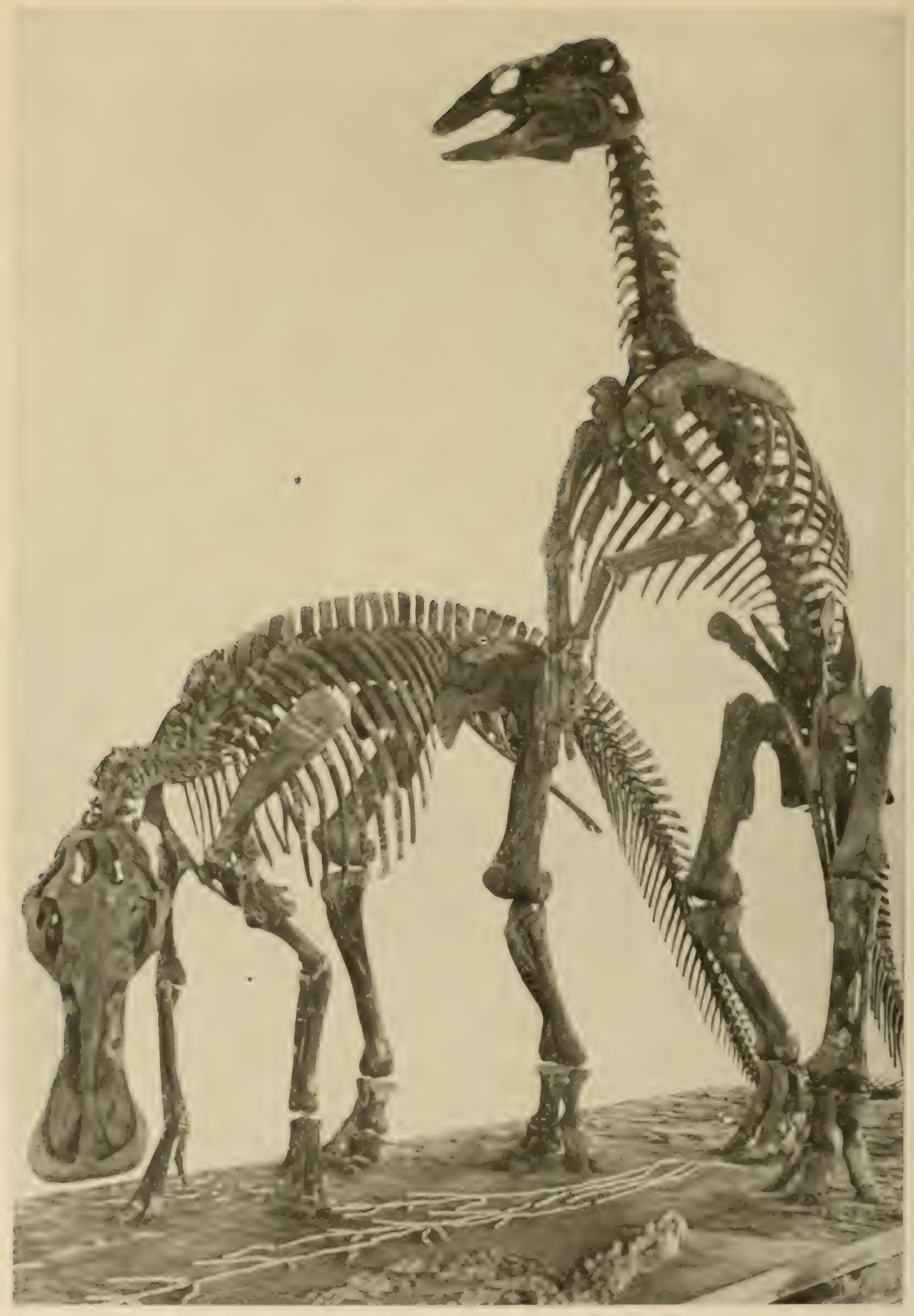

TRACHODONS OR DUCK-BILLED DINOSAURS

Fossil reptiles, fiftcen to sixteen feet high and thirty feet long, with spreading webbed feet, compressed tail and duck-like bill, all of which indicate a more or less aquatic existenc? 42 
the last and most powerful of the carnivorous dinosaurs. Like dllosaurus it

Tyrannosaurus

has enormous three-toed hind legs armed with sharp claws, and smaller fore legs. Tyrannosaurus is from Montana and the matrix in which it was found is as hard as flint.

To the left of Brontosaurus are two complete specimens of the duckbilled dinosaur Trachodon. One shows the animal erect Trachodon and standing on guard, while the other is shown feeding on shellfish and plants of the Cretaceous swamps of Montana.

In the low case in front of this group is one of the most interesting reptile specimens which has ever been discovered. It is a mummified duckbilled dinosaur, Trachodon, the skin of which is wonderfully well preserved, and for the first time the character of the outer covering of this animal is fully revealed. The animal is lying on its back and, in spite of its crushed condition, its form is easily distinguishable. It probably died on a sand bank or near a shoal where the hot winds dried up the flesh until the skin adhered to the bones like a close-fitting glove, and was subsequently buried by a flood.

Other specimens shown in the hall include the smaller carnivorous dinosaurs, the horned dinosaurs with, in one instance at least, a skull seven feet in length, and giant birds possessed of teeth. There is also the finback lizard, one of the most ancient of fossil reptiles; Diadectes, a reptile with a solid-boned skull and Eryops, a primitive amphibian. The finest collection of fossil turtles in the world will be found on the south side of the hall.

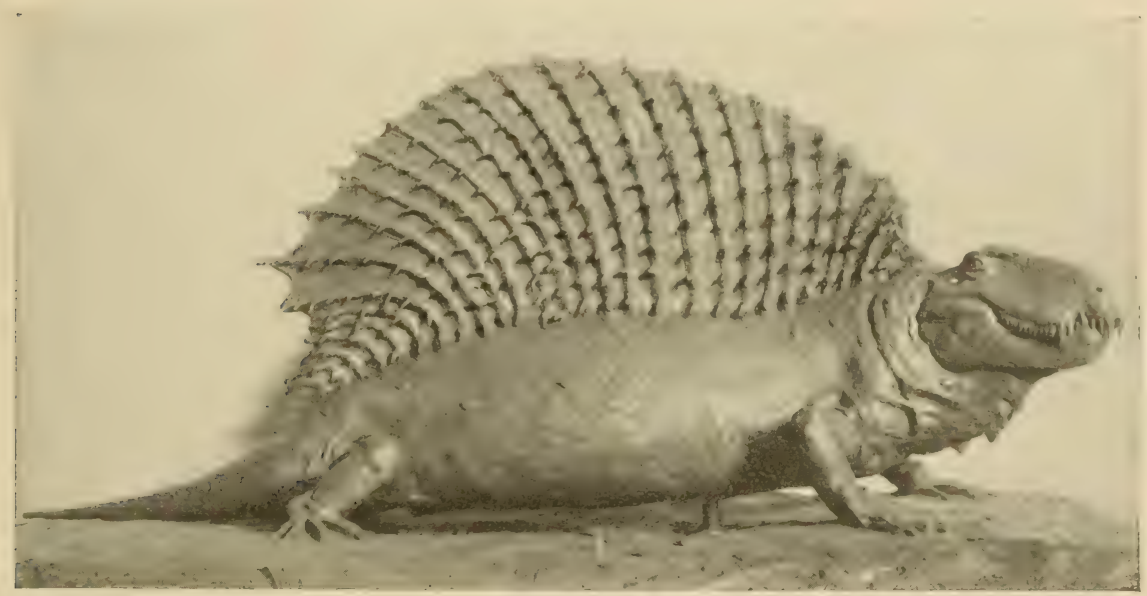

Model of Nasaurus or "Ship-Lizard," an ancient and grotesque reptile. Collected in Texas; length eight feet 
In the Tower of the Southeast Pavilion are displayed the fossil fishes which belong to a much earlier period than the mammals and reptiles,

Fossil

Fishes quite unlike any living fishes and are probably only very indirectly related to them; some were small, curiously encased in shells; others, shown in the three cases in front of the visitor, attained large size and were evidently formidable creatures. One of them in fact, Dinichthys, shown in the midelle of the gallery, was probably among the mest destructive creatures that ever lived in the sea. Its jaws were so strong that it could crush a plate of bone as thick as one's hand. Such an actual specimen, fractured in life and shcwing the marks of "teeth" is shown in a neighboring case.

The collection is so arranged that he who makes the tour can see the principal kinds of fossil fishes and is able, in a measure, to outline the history and pedigree of the entire group. He can trace the rise and fall of the early plate-covered fishes; the era of the sharks which on the one hand supplanted the earliest fishes and were in time replaced by the more efficient lungfishes and ganoids; the age of ganoids when the waters were filled with these enamel-scaled fishes; finally the age of the bony-fishes, or teleosts, the multitudinous forms of to-day, the herrings, cods, perches, whose methods of swimming, feeding and breeding are far more efficient than those of any of their predecessors.

Above the entrance are the jaws (models), spreading nine feet, of a huge fossil shark in which the actual teeth are arranged as in Jaws of the sharks of to-day, in the usual banks or rows - the teeth Suge Fossil in the hinder rows having served to replace those in front.
Shark

Such a shark probably measured from seventy to ninety feet and its race may well have become extinct, when for various reasons the enormous volume of food necessary to support it could not be maintained within its range of sea.

Fossil

Aquarium

In the first alcove to the left, by the window, is a "fossil aquarium" in which a number of models of these earliest fishes are arranged in a group, as though alive in the sea.

In the next alcove are the early fossil sharks which superseded the tribe of plated fishes just mentioned. These sharks had soft skeletons, simple Sharks

fins and a number of other primitive features which lead to the belief that all of the higher fishes, and the higher backboned animals therefore as well, were descended from them, their simpler structures becoming more complicated in many directions. In one of the early sharks here exhibited, soft parts such as muscles and gill filaments, have been petrified. 


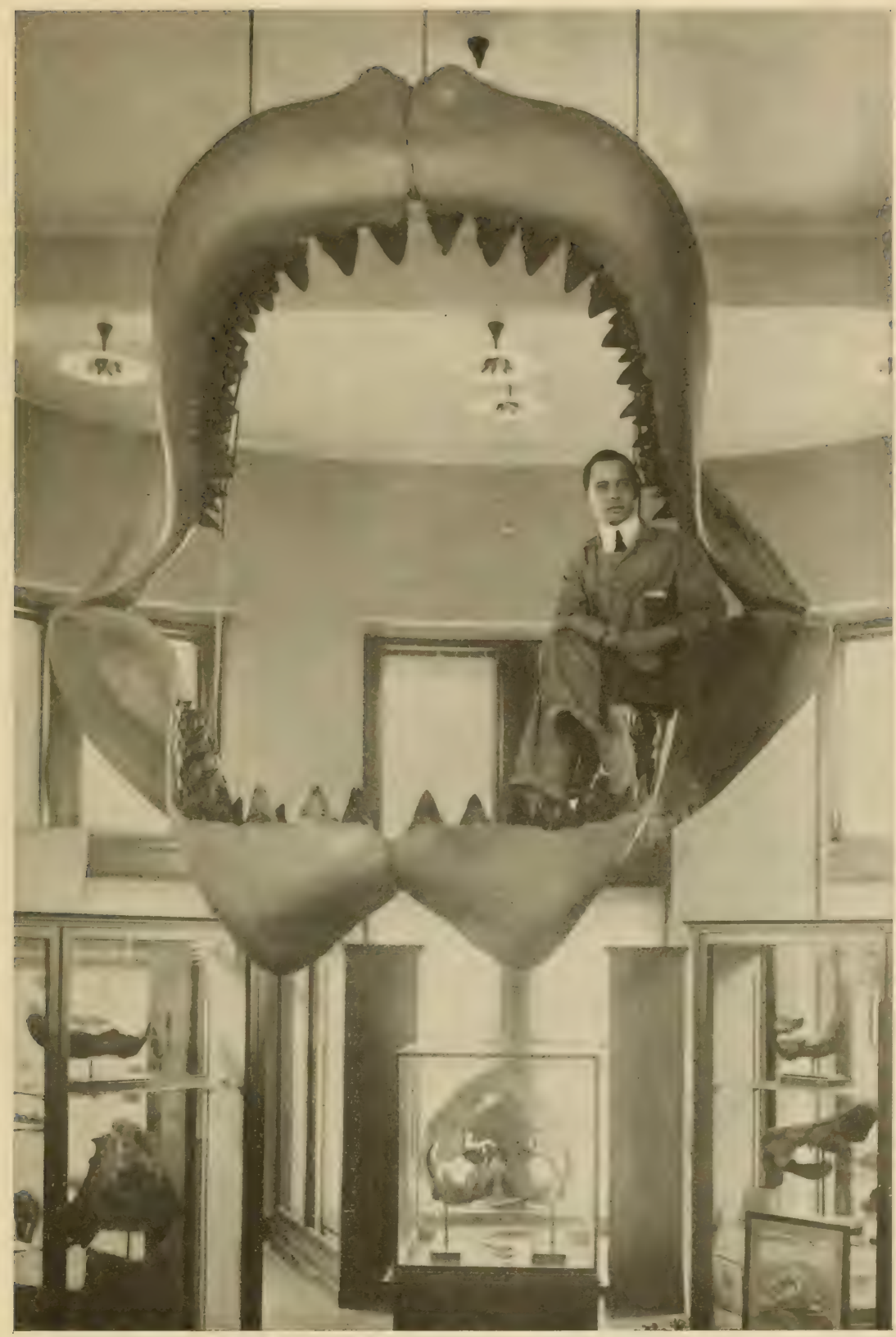

RESTORATION OF THE JAWS OF A TOSSIL SHARK

This largest and most formidable fish, living or extinct, of which we have any record frequented the icoast of South Carolina in Tertiary time. The jaws measure nine feet across; estimated length of fish, eighty feet 


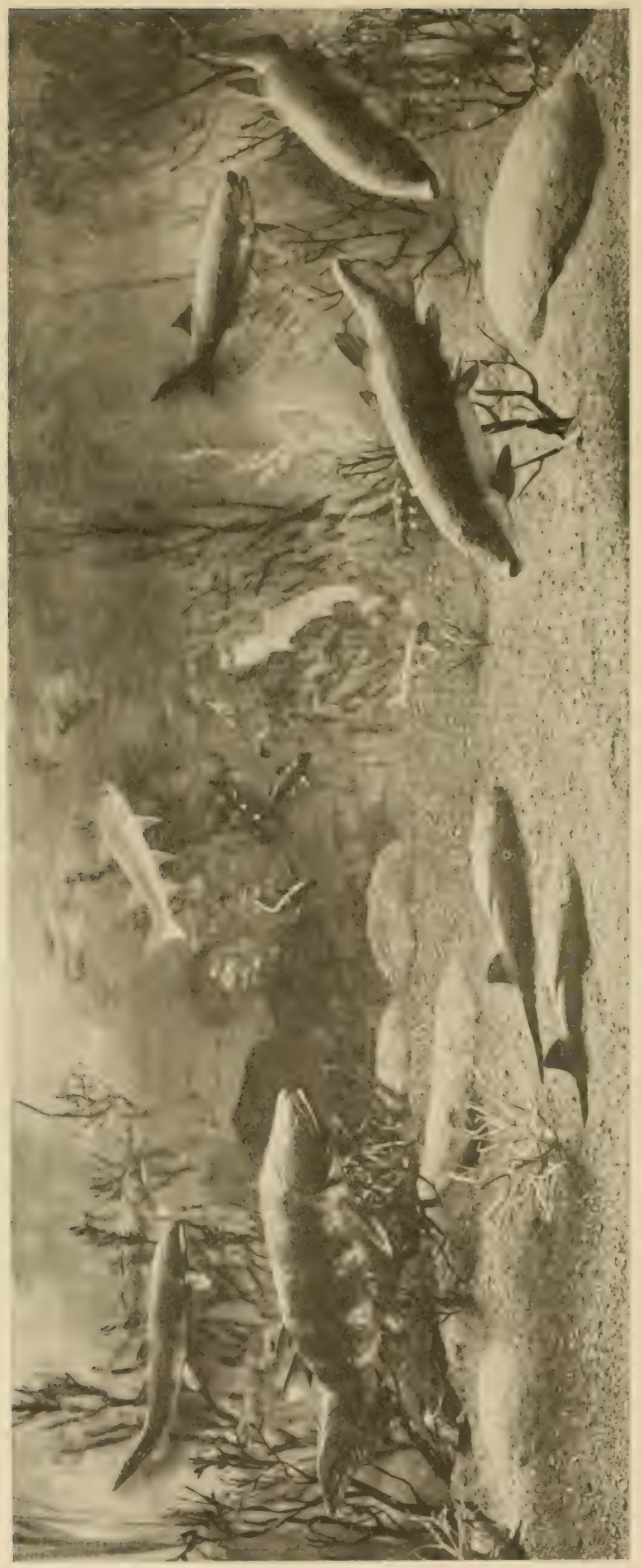

를

กิ

है

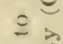

产

产

इ

표

토

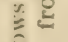

ำ

施

है 
In the third alcove appear rare fossils of silver sharks or Chimæroids, Chimæroids which appear to have been developed from a primitive race of sharks. Curiously enough fossil egg capsules of these forms are sometimes preserved, and examples are here present. In neighboring cases are shown ancient lungfishes and ganoids - groups from which all land-living quadrupeds are believed to be descended.

In the fourth alcove are shown the ganoid fishes which dominated the

\section{Ganoids}

waters during the Age of Reptiles. They were of many kinds and sizes, most of them with lozenge-shaped scales of bone, with enamelled surface. One of the few survivors (Amia) of this ancient group is here shown living (in a window aquarium), to give the visitor a clearer idea of the fishes of the "Middle Ages" of the world.

In the fifth alcove are the petrified fishes of the Age of Mammals. By. Teleosts this time nearly all of the primitive fishes like sharks, lungfishes and ganoids, had become extinct; and the common forms were bony-fishes, or teleosts, closely related to our herrings, perches, mackerels and daces.

[Return to the South Pavilion or Hall of Mastodons and Mammoths.]

\section{SOUTH CENTRAL WING}

\section{Geology and Invertebrate Palæontology}

Turning northward at the center of the Quaternary Hall containing the mastodons and mammoths, the visitor enters the South Central Wing of the building and is in the Hall of Geology and Invertebrate Palæontology. At the entrance of the hall there is a large slab of fossiliferous limestone from Kelleys Island in Lake Erie near Sandusky, whose surface has been

\section{Glacial}

Grooves smoothed, grooved and scratched by the stones and sand in the bottom of the vast moving ice sheet or glacier that covered the northeastern part of North America during the Glacial

Epoch. The front of this continental glacier is now thought by most geologists to have retreated northward across Lake Erie from 30,000 to 50,000 years ago. At Kelleys Island, the ice was moving from east to west. Just beyond the glacial groove specimen, the visitor will see an exhibit illustrating some of the results of an expedition which the Museum sent to Martinique and St. Vincent during the great volcanic eruptions of 1902-

Volcanic Bombs 1903 that devastated those islands of the Lesser Antilles chain. A set of four relief maps shows the island of Martinique and its famous volcano, Mont Pelée, at three important stages of the 
eruptions, while the nearly cases and peedestals contain relies of the ruined city of St. Pierre and the dust, stones and bread crust bombs that were thrown out in a white hot or molten condition by this volcano and by the Soufrière of St. Vincent. Some 30,000 people were killed by these outbreaks. Important geological facts were learned from the observation and subsequent study of the series of events.

At the north end of the hall, there is the reproduction of part of a marvelously beautiful cave that was discovered early in 1910 in the mining operations at the famous Copper Queen mine at Bisbee in the southeastern part of Arizona. The cave was formed by the dissolving action of water traversing joints in limestone, and its walls, roof and bottom were afterward coated with calcite (calc spar) incrustations, stalactites and stalagmites, some of which are dazzling white while others are colored green with copper salts or pink with iron compounds.

In the alcove across the hall from the cave, the visitor may see the stump and part of the roots of a large tree from an anthracite coal mine Fossilized under Scranton, Pa. Millions of years ago, in the geological Tree Stump period known as the Carboniferous, this tree grew upon the top of a thick swamp deposit of decaying regetation which ultimately became a most valuable bed of coal. The stump was left in the roof of the mine when the coal was extracted for commercial and domestic uses. It fell to the floor years after the gallery had been abandoned and was discovered only through the chance visit of a miner.

The cases along both sides and down the middle of the hall contain geological and palæontological specimens. Palrontology is the science of the ancient life of the earth; its field is the study of the fossilized shells and other hard parts and the various kinds of imprints left by the animals formerly inhabiting the seas and lands, and preserved in deposits which now form our stratified rocks. As normally the upper layers of a series of strata are more recent than the lower, the fossils reveal the succession of life forms in the earth's crust and thus are of the highest value and interest to the student of historical geology. Since, however, the remains of only a small proportion of the animals living at a given period are permanently preserved in the marine, river, lake and subaërial deposits of that period, the geological record of animal and plant forms is far from complete. Inasmuch as invertebrate animals are far less free in their movements than the vertebrate forms, they are accepted as the best determinants of the geological age of a bed of rock, even when remains of both kinds are found together. Invertebrate life too appeared on the globe far earlier than vertebrate, and remains of certain species are abundant in the lowest (oldest) of our stratified rocks.

The specimens in the cases are arranged to illustrate historical geology, 
beginning at the northeast corner of the hall with the archran rocks, which

Series to

Show

Historical

Geology

are the lowest and oldest of all and contain no fossils, advaneing regularly southward along the east side through the Cambrian, Ordovician, Silurian and Devonian systems, passing to the west side of the hall in the Devonian and continuing through the Carboniferous, Jurassic, Triassic, Cretaceous and Tertiary. Thus far the specimens are from American localities, but the northwest quarter of the hall is devoted to a synoptic series of European fossils. The cases in the middle of the hall contain overflow material from the sides. The American series is subdivided into geographical provinces, the fossils from New York State and other eastern regions being placed first and then the material from the Central West and beyond. Under the geographical subdivision the species are arranged according to their position in the scale of life - that is, following a biological classification, the lower or simpler forms being placed first. The diamond-shaped bits of emerald green paper attached to some of the specimens indicate those, more than 8,000 in number, known as "types" or "figured specimens," which have been used by James Hall, R. P. Whitfield and others in the original description and naming of species or in their elucidation.

The upper shelves of the wall cases contain particularly large or striking specimens of fossils, or blocks of rock illustrating the geological features of the horizons in which the fossils occur.

Two floor cases in the middle of the hall at the north end contain a series of rock specimens showing the geology of Manhattan Geology of Island and a very complete collection of the minerals found Manhattan Island in New York City and immediate vicinity belonging to the New York Mineralogical Club.

Attention may be called also to the collection of Michigan copper ores, orbicular granites and diorites from several parts of the world, fossil crinoids from Waldron and Crawfordsville, Indiana, fossil corals frcm the Devonian reefs near Louisville, Kentucky, fossil crinoids and an immense clamlike shell from the Cretaceous of Nebraska, fossil plants from Tertiary beds at Florissant, Colorado. The windows contain some colored transparencies from photographs of interesting scenery in the West.

[Return to the Hall of Mastodons and Mammoths and turning to the right enter the West Corridor or Gem Hall.] 


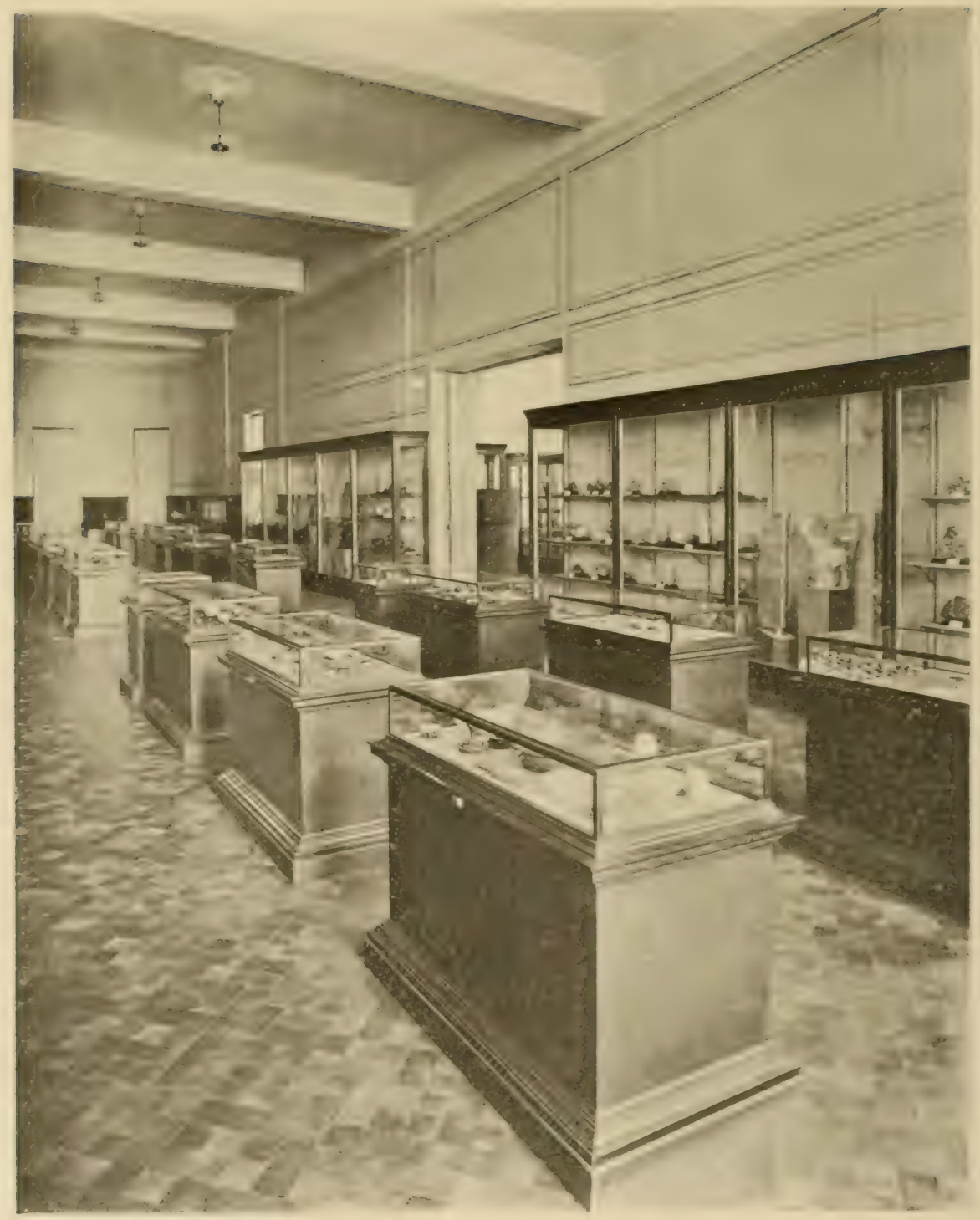

A PORTION OF THE GEM HALL

In the wall cases are many fine examples of quartz, calcite, malachite, azurite, and amethyst. In the desk cases are cut and uncut diamonds, sapphires, topaz and other gems. The collection, presented to the Museum by Mr. J. P. Morgan, includes many large and rare forms which could not be duplicated 


\section{WEST CORRIDOR}

\section{Geis and Precious Stones}

The $\mathrm{I}^{\prime}$ st Corridor contains the Morgan gem collection. This splendid series of gems and precious stones was presented to the Museum by Mr. J. P. Morgan, one of the founders and a Trustee of the institution. It includes many large or rare forms, some of which could not be duplicated. In the wall cases are fine samples of quartz, calcite, gypsum, and Iceland spar which makes a double refraction of light rays thereby causing

Gems and Precious Stones objects seen through it to appear double; malachite of such soft texture that it appears more like velvet than stone; tourmaline of varied hue; azurite of indescribable tones of blue, and enormous slabs of amethyst crystals, the last named among the largest and finest specimens ever taken from a mine. The smaller and more valuable gems are shown in the desk cases, the raw material or uncut gem being placed in the center of each case and the cut stones around it. The diamonds, sapphires, the topaz, amber and native gold are exhibits of unusual interest. Case labels describing the formation, properties and localities of each gem are attached to the case. [The collection of gems is more fully described in Guide Leaflet No. 4.]

\section{SOUTHWEST WING}

\section{Minerals}

Next beyond the Gem Hall is the Southwest Wing or Hall of Minerals. At the entrance to the hall is a case in which recent acquisitions are placed.

\section{Bement} Collection

The general collection of minerals consists chiefly of the wellknown Bement Collection which contains specimens representing species of the known minerals of the world. Not only is the collection noted for its numbers, but in many instances the beauty and size of the individual specimens are quite unsurpassed in other collections.

The more attractive specimens are displayed in cases arranged down the center of the room. The remainder of the collection is arranged according to the classification of minerals. In the first cases on the right or left the visitor is introduced by models to the various types of crystallization. Each mineral has a characteristic form of crystallization which is one of the means of identifying it. The distribution of the more important minerals is indicated on maps. [See Guide Leaflet No. 4.] 


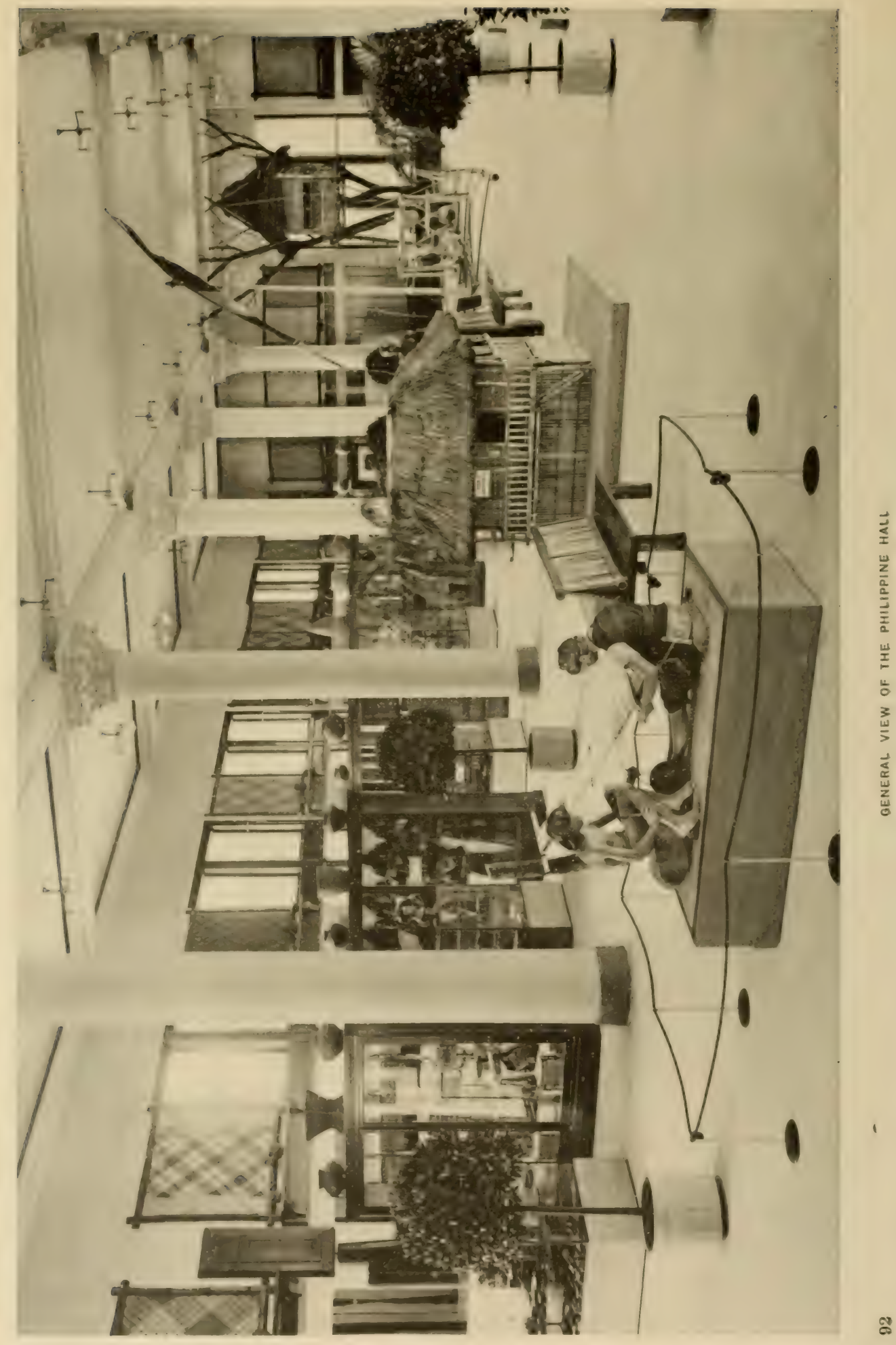




\title{
SOUTHWEST PAVILION
}

\author{
Collections from the South Sea Islands
}

Entering the Southwest Pavilion beyond the Hall of Minerals the visitor will find specimens pertaining to the natives of the Pacific Islands. The wall cases contain examples of war implements, tapa or bark cloth, sacred masks, boomerangs and armor.

The cases in the center contain Kava bowls, head rests, shell and ebony armlets and other ornaments, betel spatulas, ceremonial paddles, hats, mats and baskets. These people follow the custom of tattooing themselves. Their occupations as here detailed are peaceful rather than warlike. The swinging picture-frames on the left of the entrance midway down the room give some idea of the dress, customs, and pastimes of the Samoan Islanders. Note the delicate workmanship expended on the feather capes worn as robes of honor by great chiefs of Sandwich Islands. The jade boulder from New Zealand supports a figure representing a Maori warrior in an attitude of defiance.

\section{WEST WING}

\section{Collections from the Philippines}

The hall due north beyond the Hall of the Pacific Islands is devoted to a collection from the Philippine Islands. The installation here as in the African hall is geographical. The specimens of wood along the walls are Living Tribes Philippine woods. The palm leaf mats above the windows of the Philippine around the hall are in some cases very beautiful. The brassIslands work, boar-bristle tooth brushes, necklaces, shell bracelets, knives, spears, bead-ornamented combs, medicines, guitars, horse accoutrements evidence superior workmanship. These people present a higher civilization than their South Sea Island neighbors. The exhibit of clothing distinctive of each tribe is very complete. The model at the entrance depicts a woman weaving a garment similar to some of those seen in the cases. The house in the tree at the end of the room is a life-size copy of a tree-house such as the Lake Lanao Moros build. Full information concerning the tribes is given in various descriptive labels. 


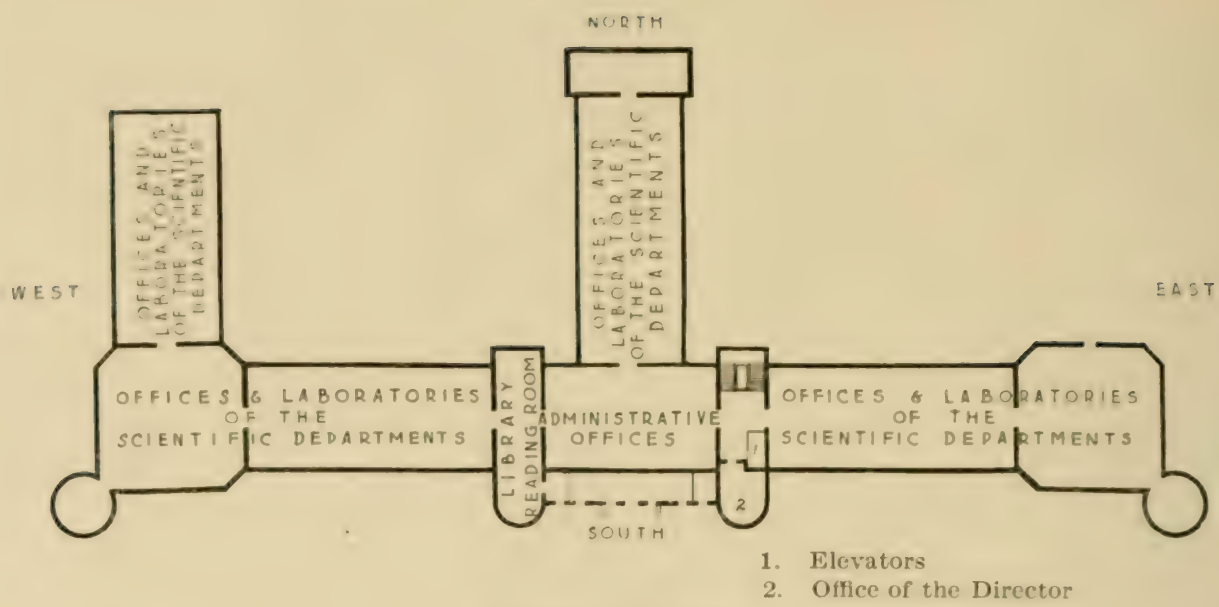

FIFTH FLOOR

The fifth floor is given over to the administrative offices, the offices and laboratories of the scientifie departments and the library. The reading room of the library is located in the west corridor, and is open free daily from 9 A. M. to 5 P. M. except Sundays and legal holidays. The library is a reference library containing some 60,0 ofo volumes deroted to the natural sciences, a collection that has been accumulated for a three-fold purposenamely, to supplement the exhibits of the Museum with the literature pertaining to them, to supply the natural history student with the most important scientific works, and to furnish the general reader with the more popular books such as give accurate but less detailed information, and at the same time stimulate a more intense study of nature.

These aims in building up the collection of books have been fulfilled to such an extent that the Library now contains over 15,000 volumes on zoology, comprising many of the extremely rare and interesting monographs in ornithology; an excellent collection of 3500 volumes in entomology including many of the rare classics and a 2000 volume collection in conchology containing the standard works of Küster, Reeve and Binney. There is also a well selected collection of 2500 volumes in anthropology including many of the older works relating to the North American Indian; an excellent collection of 3500 volumes in geology enriched by the library of the late Professor Jules Marcou; a collection of 5000 volumes in palientolog. to a large extent composed of the Osborn Library of Vertebrate Palæontology; also an unusually complete collection of more than 25,000 volumes of natural science periodicals. These with the Bickmore Library of travels and a small but carefully selected assortment of books relating to scientific vovages give the library of the Museum important educational value. A rack in the reading room contains current issues of many scientific periodicals. 


\section{INI)EX}

Page numbers of illustrations are set in heavy face type

Administrative Offices 94

African collections 41

"Ahnighito" meteorite 10, 14

Allosaurus 81

Altar stone 40

Amphibians 51-53

Anatomy and Physiology, Department of 39

Annelids 31

Antelope Group 47, 49

Archrology, Mexico and Central America 38, 39

Aretic-Alpine Bird Life Group 62

Arthropods 31

Asia, Collections from 69

Assembly Halls 13

Astronomical clock $\mathbf{3 4}, 35$

Auditorium 18

Auduboniana 64

Auk 44

Bement Collection 91

"Big Tree" of California 33

Birch bark kettle $\mathbf{1 9}$

Bird Feeding Group 64

Bird Groups 57-64

Bird Rock Group 64

Birds, Local 64

Birds of paradise 44

Birds of the world 43

Birds, Seasonal collection 64

Bison Group 48

Blind, Room for the 36

Booby and Man-of-War Group 62

Brandt's Cormorant Group 61

Brontosaurus 80, 81

Brown Pelican Group 61

Bullfrog Group 52, 53

Calendar Stone 40

California Condor Group 61

"Caliph" 41

Carnivores 36

Checking Room 13

Cherokee mask 19

Children's Room 36

Chilkat blankets 17

Chimæroids 87

Chinese collections 69

Clam and Oyster, Models 32

Cobb's Island Group 58, 59

Cobra Group 53

Codices 40

Congo collections 41

Copperhead Snake Group 53

Coral 30, 32
Crustaceans 32

Darwin Hall 29

Diagrams of Halls 8, 13, 35, 55, 73, 94

Dinosaur Diplodocus 81; duck-billed 82. 8:3

Dogs 35

Dogwood, Flowering 27

Duck Hawk Group 57, 59

Egret Group 60,61

Elephant head 45; "Tip" 36

Eohippus, Restoration of $\mathbf{7 7}$

Eskimo collections 17, 18; home scene 16

Eskimo woman cooking 17; fishing 18

"False Faces" 19, 20

Fishes, Recent 44

Flamingo Group 54, 56, 62

Flatworms 30

Florida Rookery Group 62

Forestry, Hall of North American 28

Fossil aquarium 64,86 ; fishes $84-87$; fishlike lizards 74; mammals of South America 75,$76 ;$ mammals of the Tertiary Period 77; Reptiles 81-83; vertebrates, Foreword on 73

Fossil sharks 84 ; jaws of 84,85

Fossilized tree stump 88

Fossils, Age of 73

Foxes 45

Funeral urns 40

Fur Seal Group 49

Ganoids 45, 84, 87

Gem Hall 90

Gems and Precious stones 91

Geology 87; historical 89; of Manhattan Island 89

Giraffe and giraffe camel 80

Glacial grooves 87

Gold and silver work 67

Golden Eagle Group 62

Goose (Wild) Group 63

Grant's caribou 49

Grebe Group 63

Ground Sloth Group 75, 76

Hackensack Meadow Group 59

Haida Canoe 15, 17

Hares 48, 55

Heron Group (Florida Great Blue) 59

Hippopotamus "Caliph" 41; pygmy 80

Horse, Evolution of the 77, 78, 79

Horses, Skeletons of modern 76

Indian societies 23

Indians, Alaskan 16; Apache 26, 28; Blackfoot 22,23 ; British Columbia 16; Cree 
21, 23: Delaware 21; Hopi 24, 26; Iroquois 19, 20; Local New York 20, 21; Memomini 21; Mexican 26; Navajo 24, 25. 26; New York 19, 20; North Pacific Coast 16, 17; Ojibwa 21; Pima 24, 26: Plains 23, 26, 28; Pueblo Bonito 24; Rio Grande Pueblo 24; Seminole 21; South American 65-69; Southwest 24-26; Winnebago 21; Woodlands 19-21; Zuni 24, 26 Information Bureau 13

Insects 31,32 ; habits 71 ; importance 71 ; life 71 ; local collection 72

Invertebrate palawontology 89

Invertebrates 29

Jesup Collection of North American Woods 25

Jesup Memorial statue 12, 13

Klamath Lake Group 58, 62

Labrador duck 44

Library 94

Lion (Barbary) 36, 37

Loon Group 63

Mammals 35; of North America 45; of the Polar Region 49; of the world 70

Maori warrior $\mathbf{7 2}, 93$

Marine Habitat Group $\mathbf{3 0}$

Mastodons and mammoths 74,76

Medicine pipe 23

Memorial Hall 13

Meteorites 10, 14, 18

Mexican archeology, Hall of $\mathbf{3 8}$

Minerals 91

Mink 46

Mitla ruins 39

Moccasin (Gros Ventre) 21

Mollusks 32,69

Monkeys 55

Monuments, Ancient Mexican 39

Moose Group 48

Mosquito models $\mathbf{3 1}, 32$

Mountain Sheep Group 49

Mulandi carved sticks 42

Mummy bundles 65, 68

Mummy, Chilean 67

Mural decorations 18

Museum building 4; administration and support 11: admission 11; history 11; location 11

Muskrat 46,48

Naosaurus 83

Natural History Reading Room 36

Navajo blankets 25,26

North Pacific Hall 15, 16, 18

Oposeum 45, 46

Orang-utan Group 55

Orizaba (iroup) 58

Pacifle Islands Collections 93

Peary musk ox 51

Peary sledges 28

Philippine collections 93: Hall 92
Pigs, giant 80

Pioncers of American science 14

Polar bear 50, 51; expeditions 28; maps 28

Polyps 30

Power room 18

Prairie Chicken Group 63

Prehistoric Man 41

Primitive Man 55

Protozoa 29

Ptarmigan 43, 44

Public Health, Department of 39

Pueblo villages 24

Racoon 45, 46

Religious ceremonies 17

Reptiles 51-53

Rhinoceros 80

Rodents 55

Roosevelt elk 51

Rotifers 31

Roundworms 31

Sage Grouse Group 63

Sandhill Crane Group 59

San Joaquin Valley Group 61

Sea-mats 31

Serapes 26

Shells 69

siberian collections 69

skunk 46

Solar System, Model of 14

Sponges 29, 30

Squirrels $46,48,55$

Starfish 30, 31

Stelæ 39

Sun dance 23

Synoptic Series (Animal Kingdom) 29

Tertiary Hall 77

Teleosts $45,84,87$

Textiles (South American) 67

Tipi 22, 23, 28

Totem poles $\mathbf{1 7}$

Trachodon $\mathbf{8 2} .83$

Trephined skulls $\mathbf{6 6}, 67$

Turkey Vulture Group 61

Tyrannosaurus $\mathbf{8 1}, 83$

Vertebrates (Synoptic Series) 32

Virginia deer $\mathbf{4 8}$

Volcanic bombs 87

Walrus 51

Wampum 20

Ward-Coonley meteorites 18

Warren mastodon 76

Water Turkey Group 59

Weasel Group $\mathbf{4 6}$

Whale. finback 44; humpbacked 70; North Atlantic right 55 ; sulphur-bottom 70

Wild Turkey Group 59

"Willamette" meteorite 11

Woodchuck 46,48

Zudiac, signs of 14 


\section{American Museum of Natural History}

\section{GENERAL GUIDE}

TO THR

\section{EXHIBITION HALLS}

NO. 35 OF THE GUIDE LEAFLET SERIES PUBLISHED BY THE MUSEUM, NOVEMBER, 1911 
No. 18. - THE MOUNTED SKELETON OT BRONTOSAURUS, By W. D. Matriew, Ph.D., Associate Curator of Vertebrato Puleuntology. April, 1905. Out of pmit.

No. 19.-THE REPTILES OF THE VICINITY OF NEW YORK CITY. BY Rarmond L. Drmars, Curator of Jeptiles, New York Zoölugical Park. July, 1005; Out of print.

No. 20. - THE BATRACHIANS OF THE VICINITY OF NEW YORK CITY. By Raymond L, Dimpars, Curator of Reptiles, New York Zoological Park October, 1005: Price, 15: cants.

No. 21. - THE DEVELOPMENT OF A MOLLUSK, By B. E. Dahlgren, D. M. D. January, 1906. Out of print.

No. 22. - THE BIRDS OF THE VICINITY OF NEW YORK CITY. By FranK M. Chapman, Associate Curator of Mammalogy and Omithology. April-July, 1906. Price, 15 cents.

No, 23.- THE SPONGE ALCOVE. By Rox W. MrNer, Assistant Curator of Invertebrate Zoölogy. October, 1906. Out of print.

No. 24. - PERUVIAN MUMMIES. By Charrus W. Mrad, Department of Ethinology. Mareh, 1007 , Price, 10 cents:

No. 25.- PIONEERS OF AMERICAN SCIENCE. Memorials of the naturalists whose busts are in the Foyer of the Museura. April, 1907. Out of print.

No. 26. - THE METEORITES IN THE FOYER OF THE AMERICAN MUSEUM OF NATURAL HISTORY. By EDMUND OTxs. Hover, Ph.D., Associate Curator of Geology. December, 1907. Price, 10 cents.

No. 27.-The Malaria Mosquito. By B. E. Dahlgren, D. M. D. Assistant Curator of Invertebrate Zoölogy. April, 1908. Out of print.

No. 28.-THE HABITAT GROUPS OF NORTH AMERICAN BIRDS. By Franx M.Chapman, Curator of Ornithology. February, 1909. Price; 15 cents.

No. 29. - THE INDIANS OF MANHATTAN ISLAND AND VICINITY. By. Alanson Skinner, Department of Anthropology. September, 1909. Price, 10 conts.

No. 30.-THE STOKES PAINTINGS REPRESENTING GREENLAND ESKIMO. November, 1909. Price, 5 cents.

No. 31.-BRIEF HISTORY OF ANTARCTIC EXPLORATION. March, 1910. Prices, tio cients.

No. 32.- TREES AND FORESTRY. By Mart Crntha Dickgrson, B. S., Curator of Woods and Foreetry. September, 1910. Price, 15 cents.

No. 33.-THE PROTECTION OF RIVER AND HAPBOR WATERS FROM MUNicipal WAStes. By Charlig-Edward Amory Winglow, Curator of Public Health. April, 1911. Price, 10 cents.

No. 34,-PLANT FORMS IN WAX. By E. C. B. FASsem. November, 1911. Price, 10 cents.

No. 35.-GENERAL GUIDE TO THE MUSEUM:. Prepared by Garge H. 'Strerwood, Curator of Public Instruction. November, 1911. Price 15 cents. 


\section{Guide Leaflets published by the}

\section{AMERICAN MUSEUM OF NATURAL HISTORY}

\section{For Sale st the Museum}

No. 1.-THE BIRD ROCK GROUP. By F. M. Chapman, Aseciate Curator of Marmualogy and Ornithology. Outober, 1001. Prics, 10 cents.

No. 2- THI SAGINAW VALLEY COLLECTION, By H. I. Smiт, Asistant Curator of Arcbrology. December, 1801. Price, 10 cents.

No. 3.- THE HALL OF FOSSIL VertebRateS. By W. D. Mattgev, Ph.D., Assistant Curator of Vertebrate Palseontology. January, 1902. Det of print.

No. 4-THE COLLECTION OF Mineral8, By Louis P. Gratacar, A. M. Curator of Mineralogy. February, 1002. Revised edition, May, 1904. Price, 10 cents.

No. 5.-NORTH AMERICAN RUMINANTS. By J. A. AluEN, Ph.D. Curator of Mammalogy and Ornithology. March, 1902. Revised edition, February, 1904. Price, 10 cents.

No. 6.-THE ANCIENT BASKE'T MAKERS OF SOUTHEASTERN UTAF By Grorgr H. Pepper, Assistant in Anthropology. April, 1902. Second edition, May, 1909. Price, 10 cents.

No. 7. - THE BUCIERTLIES OF THE VICLNITY OF NEW YORK CITY. By Wilina Brotenmúlter, Curator of Entomology. May, 1902. Out of print.

No. 8. THE SEQUOIA. A Historical Review of Biological Science. By Gronos H. Sherwood, A. M.s Assistant Curator. November, 1902. Price, 10 cents.

No. 9. - THE EVOLUTION OF THE HORSE, By W. D. MATTHW, Ph.D., Associate Curator of Vertebrate Palnontology: January, 1903. Second edition, Mry, 1905. Out of print.

No. 10. - THE HAWK-MOTHS OF THE VICINITY OF NEW YORK CITY By Writam Beotenmullere, Curator of Entomology. February, 1903. Price, 10 cents.

No. 11. - THE MUSICAL INSTRUMENTS OF THE INCAS. By C. W. MDAd, Assistant in Archoology. July, 1903. Price, 10 conts.

No. 12. THE COLLECTION OF FOSSIL VERTEBRATES. By W. D. MaT THEw, Pb.D., Associate Curator of Vertebrate Palæontolugy. October, 1903. Out of Prinl.

No. 13. - A GENERAL GUIDE TO THE AMERICAN MUSEUM OF NATURAL HISTORY. January, 1904. Out of print.

No. 14-BIRDS' NISTS AYD EGGS. By Frant M. Chapman. Absociato Curator of Mammalogy and Crnithology. April, 1904. Reprinted, February, 1905. Out of print.

No. 15.-PRIMTTIVE ART. July, 1904. Price, 15 cents.

No. 16. - THE INSECT-GALLS OF THE VICLNITY OF NEW YORK CITY. By Willam Bzorenmöllez, Curator of Entomology. Oetober, 1904. Out of pint.

No. 1\%-THE FOSSIL CARNIVORES, MARSUPIAIS AND SMALL MAMMAIS IN THE AMERICAN MUSEUM OF NATURAL HISTORY. By W. D. MAxmeaw, Ph.D., Associste Curator of Vertebrate Paleoctology. January, 1005. Out of print.

(Contirued on pege s of ecter.) 




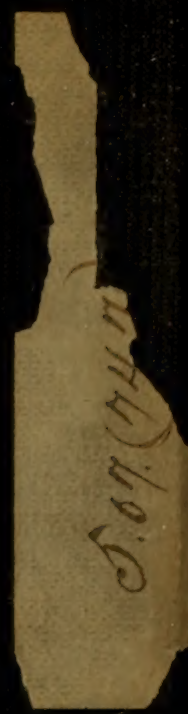

